\title{
Demand Response in the West: Lessons for States and Provinces
}

\author{
June 2004 \\ Western Interstate Energy Board \\ 1515 Cleveland Place, Suite 200 \\ Denver, CO 80202 \\ 303 573-8910 \\ www.westgov.org/wieb
}

\author{
Principal Authors \\ Matt Lowry \\ Sharon Irwin \\ Eric Waeckerlin
}

Prepared for the

U.S. Department of Energy 


\begin{abstract}
This paper is submitted in fulfillment of DOE Grant No. DE-FG03-015F22369 on the experience of western states/provinces with demand response (DR) in the electricity sector. Demand-side resources are often overlooked as a viable option for meeting load growth and addressing the challenges posed by the region's aging transmission system. Western states should work together with utilities and grid operators to facilitate the further deployment of DR programs which can provide benefits in the form of decreased grid congestion, improved system reliability, market efficiency, price stabilization, hedging against volatile fuel prices and reduced environmental impacts of energy production. This report describes the various types of DR programs; provides a survey of DR programs currently in place in the West; considers the benefits, drawbacks and barriers to DR; and presents lessons learned and recommendations for states/provinces.
\end{abstract}

This report was prepared with support from the U.S. Department of Energy under Grant No. DE-FG03-015F22369. The views expressed in this report are the authors' and do not represent those of the U.S. Department of Energy. 


\section{Table of Contents}

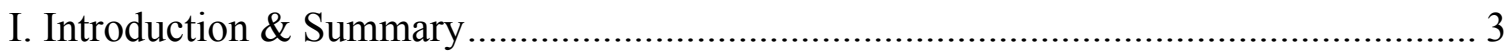

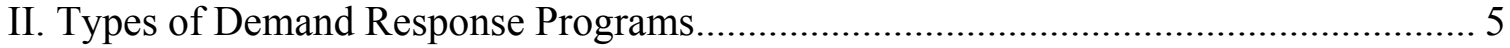

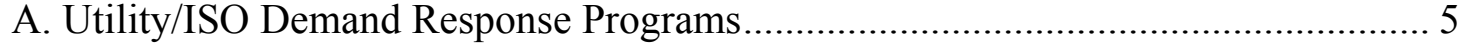

B. State/Provincial Demand Response Options ...................................................... 7

III. Benefits \& Drawbacks of Demand Response ................................................... 7

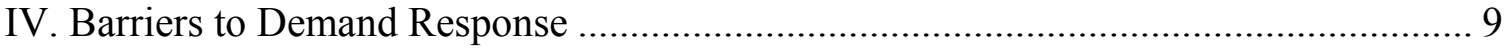

V. Demand Response Programs in the West .............................................................. 11

A. Utility/ISO Demand Response Programs............................................................. 11

B. State Sponsored Demand Response Related Programs in the West...................... 13

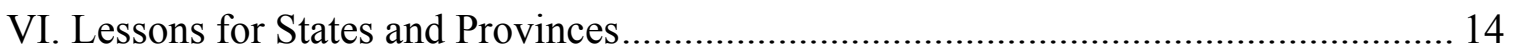

A. Results of State/Province Survey ................................................................... 14

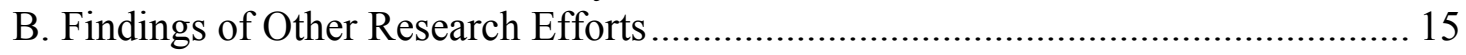

C. Recommendations for States/Provinces ............................................................. 16

Appendix A - Summary of Western States/Provinces Demand Response Programs

Appendix B - State/Provincial Survey Responses

Appendix C - Western Interconnection DR Grant Timeline 


\title{
List of Acronyms
}

\author{
DR - demand response \\ FERC - Federal Energy Regulatory Commission \\ ISO - independent system operator \\ LSE - load serving entity \\ NERC - North American Electric Reliability Council \\ RTP - real time pricing \\ TOU - time of use \\ UDC - utility distribution company
}




\section{Introduction \& Summary}

The California energy meltdown of 2000-2001 and the blackouts in the Northeast during the summer of 2003 highlighted many of the fundamental weaknesses of the country's aging electrical system. While the causes of these crises were myriad, the solution appeared to be singular. The familiar call for a supply-side fix of more generation and transmission rang through legislative chambers and boardrooms. Even with the emphasis state and federal regulators have placed on competitive markets for electricity, comparatively little attention has been paid to the other half of functioning markets: demand.

Demand operates in electricity markets through demand response programs which are "mechanisms for communicating prices and willingness to pay between wholesale and retail power markets, with the immediate objective of achieving load changes, particularly at times of high wholesale prices." " Demand response can be initiated from either side of the meter. Customers can choose to take part in dynamic pricing programs in which they are exposed to direct price signals and adjust their consumption as they see fit. Alternatively, transmission owners and load serving entities (LSEs) can call upon customers in load reduction programs to reduce demand in exchange for lower rates or financial payments.

Stakeholders all across the electrical system benefit from demand response. The resource relieves grid congestion, improves system reliability, enables the efficient operation of markets, stabilizes prices, and dampens the effects of market power. Demand response is generally less costly than supply-side measures in meeting load growth, it offers a hedge against the risk of volatile fuel prices and avoids the environmental impacts of energy production.

Demand response faces the same barriers that efficiency measures do. The primary challenge is that suppliers of energy and owners of the transmission/distribution grid have an economic disincentive to embrace demand response. Generators profit from high peak prices. Grid operators earn revenues based on throughput over their wires. Reduced electric consumption prevents the maximization of revenues by generation and transmission companies. Further, most current ratemaking practices and market operations insulate electric customers from real-time price signals, preventing them from identifying the cost savings achievable by adjusting consumption.

It is essential that demand actively participate in electricity markets to ensure reliable service at a reasonable price. Given the inherent industry barriers to demand-side resources and the states' jurisdiction over retail markets, government has a special role to play in mobilizing this often neglected component of electricity markets. The Federal Energy Regulatory Commission has made it clear that demand response should play a

\footnotetext{
${ }^{1}$ Braithwait and Eakin, The Role of Demand Response in Electric Power Market Design 15 (2002).
} 
significant role in the operation of RTOs and many states have supported DR through their respective resource planning processes.

This paper is submitted to complete the requirements under DOE Grant No. DE-FG03015F22369 on state experience with demand response in the West. Section II describes the various types of demand response and related programs. Section III addresses the benefits and drawbacks of demand response. Section IV covers the barriers to demand response. Section V looks at the specific programs available to electric customers in the West. Section VI recounts lessons learned from this and other research efforts and provides recommendations on steps states and provinces can take to facilitate the use of demand response.

Appendix A contains the report, Summary of Western States/Provinces Demand Response Programs. Appendix B features western states/provinces' responses to survey questions on implementing demand response programs in their jurisdictions. Finally, a timeline of WIEB's activities under this grant can be found in Appendix C.

\section{Summary Recommendations}

- States/provinces should set goals for load reductions and support the widespread use of demand response (DR). All customer classes should be able to participate in a wide range of easy to understand DR programs. States/provinces should help load serving entities (LSEs) educate customers about how demand response works and how they can benefit. Programs should feature load reduction capability payments for participation, and accurately measure the savings achieved.

- States/provinces should address the jurisdictional complexities posed by DR programs in both wholesale and retail market. Demand response is a central theme in FERC's effort to standardize the bulk trade of electricity. State inaction on DR may result in some loss of control over the role these resources play in residents' energy decisions. PUCs should ensure that retail DR programs are coordinated with ISO programs and work together with FERC, operators of the system and utility distribution companies (UDCs) and LSEs to address barriers and encourage DR. ${ }^{2}$

- States/provinces should consider a move away from standard-offer default retail electric rates based on pre-determined customer class average load profiles and subject to rate caps. Such rate structures offer customers little incentive to adjust electricity usage. Alternative load profiles reflecting the control of known load components (e.g., residential hot water heaters and air conditioners) should be developed. Buy-back rates should be deaveraged to reflect the true marginal costs of delivering power during peak demand periods and/or over congested portions of the grid. States/provinces could go further by mandating the use of interval meters by all customer classes and adopting a performance-based regulation regime in which LSEs are granted cost recovery based on measures other than system throughput.

\footnotetext{
${ }^{2}$ Kathan, Policy and Technical Issues Associated With ISO Demand Response Programs 49 (2002).
} 
- To facilitate approval and cost recovery for DR programs, state PUCs should rule on several unresolved issues critical to the operation of DR. PUCs should specify who will install and own advanced metering, communications and control equipment and who should have access to the data generated. PUCs should ensure fair cost recovery for distribution companies and LSEs participating in wholesale DR programs. The calculation of customer baseline loads should be standardized to avoid issues of customers "gaming" DR programs. And PUCs should undertake research to assess the costs, benefits and value of DR for use in ratemaking proceedings.

\section{Types of Demand Response Programs}

Demand response (DR) programs are typically administered by LSEs who face the pressures of meeting peak loads and responding to system emergencies. With FERC's push for competition in the bulk electric market and the formalization of independent transmission operators, demand response programs are increasingly being offered at the wholesale level by ISOs, RTOs and other operators of the system. Demand response customers at this level include LSEs, distribution utilities or energy marketers.

States/provinces don't generally operate their own utilities or wires systems and thus can offer little in the way of actual demand response programs. However, their jurisdiction over retail markets and other policy mechanisms give them control over the nature of their electric systems.

The reduction of electric consumption through demand response can be thought of in terms of price response and load response. Under price response programs, customers make economic decisions on their electric usage based on exposure to variable prices. Load response programs have a longer history and permit LSEs and operators of the system to request or demand load reductions from participating customers when supply looks tight. Load response programs have historically served more of a reliability function than a market function.

\section{A. Utility/ISO Demand Response Programs}

\section{Dynamic Pricing}

Dynamic pricing is the common term for price response programs that expose participating customers to variations in the wholesale marginal cost of electricity. Under Real Time Pricing (RTP), prices vary on an hour-ahead or a day-ahead basis and are transmitted to customers via radio, the internet or wireless communications. All price risk is born by RTP customers. This stands in contrast to Seasonal and Time of Use Pricing (TOU) where rates do not reflect real-time prices in wholesale markets, but instead are an approximation of real time prices over a period of time ranging from an entire season to a couple of hours. In this way, the entity administering the program shares some price risk 
with participating customers. Communications equipment is not necessary in seasonal and TOU pricing since customers are given price information upon entry to the program. ${ }^{3}$

\section{$\underline{\text { Interruptible and Voluntary Load Reduction }}$}

Interruptible and voluntary load reduction programs involve agreements whereby customers reduce their electric consumption at the request of LSEs or operators of the system in return for lower rates or financial payments. Compliance with the request may be voluntary or mandatory and payments can be made to customers in advance or at the time of the reduction.

Direct Load Control allows LSEs to manage the operation of customer appliances such as air conditioners and water heaters via radio signal, the internet or wireless communications. Customers are typically paid through rate discounts or monthly bill credits. Load reductions are usually mandatory, with substantial penalties for nonperformance. ${ }^{4}$ Dispatchable Standby Generation is similar, but involves utility dispatch of customers' on site generators operating in parallel with the distribution grid. Often, the utility assumes responsibility for the unit's maintenance and fuel costs.

Interruptible Load programs are traditional reliability programs which yield large load reductions $(>1 \mathrm{MW})$ via the interruption or reduction of electric service to industrial facilities and the like (e.g., refining, mining, manufacturing, food processing or water treatment). Interruption could be required at any time and little notice is necessary, perhaps an hour or just ten minutes. Participating customers qualify for rate discounts and face stiff penalties for non-compliance (e.g., 30x rate increase) ${ }^{5}$. The LSE or operator of the system is usually limited to a maximum number of interruptions per participant during a certain period (e.g., year). ${ }^{6}$

Curtailment or Demand Reduction programs offer an alternative to interruptible programs for smaller customers (e.g., office and retail). Such programs require smaller load reductions (200-1000kW), allow fewer curtailment requests and feature smaller penalties for noncompliance. Curtailments are often limited to certain dates and times, giving the customer more certainty in the management of their facilities. Participating customers are compensated through bill credits based on the amount of load reduction and applied against standard tariffs. ${ }^{7}$ The level of requested reductions can be event driven or predetermined.

Demand Buyback programs provide customers with greater flexibility than interruptible or curtailment programs. Utilities set program standards such as minimum reduction levels and necessary metering and communications equipment before signing up customers. The utility can then notify participants of its desired level of reductions and the price it is willing to pay.

\footnotetext{
${ }^{3}$ NPCC, Demand Response - Issue Paper in Preparation for the $5^{\text {th }}$ Power Plan 7 (2002).

${ }^{4}$ Braithwait and Eakin, supra note 1, at 16.

${ }^{5}$ Rosenfeld et al., Dynamic Pricing, Advanced Metering and Demand Response in Electricity Markets 6 (2002).

${ }^{6}$ AESP, Peak Load Management or Demand Response Programs: A Policy Review 9 (2001).

${ }^{7}$ Id. at 10 .
} 
Participants are price-takers, free to respond to the offer with the amount they are willing to reduce. The utility decides which bids to accept and compensation is based on performance. Participants are not required to respond to offers, but there are penalties for non-performance if a customer's bid is accepted. ${ }^{8}$

Demand Bidding programs allow retail customers or their aggregators (LSEs etc.) to submit bids identifying the minimum price required for them to curtail a certain amount of load. A customer's baseline usage is established to determine the size and value of the decrement bid. Utilities or operators of the system can then dispatch a load reduction just as they would a bid from a generator in the hour-ahead or day-ahead markets. ${ }^{9}$

\section{B. State/Provincial Demand Response Options}

States do not run their own utilities or wires companies so they must rely on their regulatory and policy-making powers to further the adoption of demand response. The most direct approach would be for a legislature or PUC to require LSEs to meet a certain level of peak demand with demand response. Verifying compliance with such a mandate would be challenging since developing accurate consumption baselines for individual customers has proven contentious enough without expanding the scope to a company or state as a whole. Beyond mandating DR, states/provinces can help develop and implement the DR programs of operators of the system and LSEs. PUCs could ensure that programs conform to state regulations and are available in time for summer peaks. ${ }^{10}$

Other state options for encouraging demand response mirror those for energy efficiency in general. Programs could include: certification of metering and communication equipment; contractor training and licensing; financial incentives such as grants, loans, rebates and tax credits for the purchase and installation of metering and communications equipment; and public outreach and education efforts like industrial recruitment incentives, government participation, and demonstration projects. These programs could be funded by a system benefits charge assessed on end users' energy bills. ${ }^{11}$

\section{Benefits \& Drawbacks of Demand Response}

Demand response is the activation of a fundamental component of wholesale and retail electric markets, not a specific product, service or piece of infrastructure. As such, the benefits of demand response inure to stakeholders across the electrical system. Financial as well as social benefits should be considered when assessing the impact of demand response.

\footnotetext{
${ }^{8}$ NPCC, supra note 3 , at 8 .

${ }^{9}$ Braithwait and Eakin, supra note 1, at 16.

${ }^{10}$ Kathan, supra note 2, at 50.

${ }^{11}$ For more on public benefits charges see Eto et al., Ratepayer Funded Energy-Efficiency Programs in a Rstructured Electricity Industry: Issues and Options for Regulators and Legislators 19 (1998) or the American Council for an Energy-Efficient Economy at http://www.aceee.org/utility/index.htm .
} 
Reliability - Demand response can quickly reduce energy use during peak load and emergency conditions, helping to avoid outages, interruptions and lapses in power quality. Demand response can provide certain ancillary services necessary for the stable operation of the bulk electric grid quickly and affordably.

Cost Reduction - Companies and customers alike can avoid costs through the use of demand response. For instance the economic impact of outages and power quality fluctuations are lessened. Demand response enables utilities to avoid some of the expense of accommodating load growth through traditional supply side measures like new generation or power purchases, transmission and distribution. The costs of maintaining and procuring operating reserves and other ancillary services are reduced. Customers can shape their energy use patterns to avoid energy costs they would have incurred under average rate tariffs. Beyond avoided costs, demand response provides an overall counterbalance to high prices by displacing the highest price generation bids in peak demand periods and effectively mitigating price spikes.

Risk Management - Utilities and their customers are insulated from price volatility in the market on account of demand response' ready availability, high reliability, modularity and rapid dispatchability. ${ }^{12}$

Environment - Demand response avoids the environmental impacts of increased generation and transmission and distribution (T\&D). This is particularly significant as demand response typically displaces peaking plants which are often the least efficient. ${ }^{13}$

Market \& System Efficiency - Accurate price signals enable consumers to make wiser choices about their electricity usage. The link between price and usage contributes to the efficient operation of markets and the electrical system as a whole. As a result, market power is mitigated and congestion on the T\&D system is reduced.

Demand response is not without its downside. The utility industry's primary criticism is likely that while demand response can help reduce costs, it may also reduce revenues. Under the present cost-of-service regulatory regime, utilities stand to lose a portion of their profits, given significant levels of demand response, because they get paid to generate and transmit energy - neither of which are part of demand response. Losses would likely be more pronounced in a deregulated marketplace as competitive pressures make additional expenditures on DR less attractive. States/provinces typically have cost recovery mechanisms for DR, but the level of compensation due utilities for such programs is a source of constant debate. The attendant costs of providing access to customer usage data and expanding customer and billing services must also be considered.

${ }^{12}$ PLMA, Demand Response: Principles for Regulatory Guidance 5 (2002).

${ }^{13}$ Kathan, supra note 2, at 7 . 
Other disadvantages of demand response programs include: the cost of advanced metering and communication systems, possible economic impacts of cycling or curtailing service, and the environmental impacts of dispatching "dirtier" onsite generation. Pricing and appropriate cost recovery have proven to be challenges for regulators. Also, some load management programs have been criticized as merely being preferential rate discounts in disguise, particularly programs that are rarely activated.

\section{Barriers to Demand Response}

Much has been written about the barriers facing demand response - most notably in Hirst's Barriers to Price Responsive Demand in Wholesale Electricity Markets. The barriers to DR can be categorized as regulatory, industry, customer, and technical. The primary obstacle DR faces is the present regulatory scheme which compensates utilities and operators of the system on a volumetric basis for the generation and transmission of energy. An alternative would be to link cost recovery to the provision of electric service under a broader charge of efficiency, reliability and affordability (e.g., performancebased regulation). ${ }^{14}$

\section{Regulatory Barriers}

Most of the criticism levied at the regulatory framework in which DR competes concerns the inability of customers to receive price signals. To begin with, some regions may not have a formal wholesale market providing hourly or day-ahead prices. ${ }^{15}$ At the retail level, customer aggregation, load profiling, regulated rate plans and price caps mask realtime costs and prevent customers from seeing any connection between when and how they use electricity and the size of their bill. ${ }^{16}$ Load profiling is particularly troublesome for DR since utilities typically charge customers according to pre-determined average usage patterns for a given customer class instead of according to an individual's actual usage. ${ }^{17}$ Without knowledge of the risk of high energy costs or the scale of possible payments for load reductions, customers cannot see the value of altering their electricity usage patterns.

Regulatory uncertainty among federal and state agencies pose difficulties for DR. It is unclear whether operators of the system, LSEs or both should devise and administer DR programs given the relationship between transactions in the wholesale market and the rates charged in retail markets to cover those costs. ${ }^{18}$ At the state level, confusion over who will own metering/communications equipment and the data it generates leads to stranded cost concerns for utilities. How would a company recover the cost of DR

\footnotetext{
${ }^{14}$ For more information on performance based regulation visit the Regulatory Assistance Project at http://www.raponline.org/Pages/Feature.asp?select=17.

${ }^{15}$ Messenger, A Proposed Action Plan to Develop More Demand Response in California's Electricity Markets 22 (2002).

${ }^{16}$ Cowart, Efficient Reliability - The Critical Role of Demand-Side Resources in Power Systems and Markets 29 (2001).

${ }^{17}$ Kathan, supra note 2, at 37.

${ }^{18}$ Messenger, supra note 15 , at 22.
} 
equipment if a participating customer switched to a different supplier in a competitive market? ${ }^{19}$ Another cost recovery concern is the lack of research and consensus on what should be valued in demand response (energy, capacity etc.) and what it should be worth in rate cases before state commissions. ${ }^{20}$

Other regulatory barriers to DR stem from outdated language in laws and regulations governing the electric industry. Some states' utility regulation legislation constrains the definition of "rates" so as to effectively prohibit DR programs (e.g., rates must be fixed in advance, not variable). ${ }^{21}$ While the North American Electric Reliability Council (NERC) is in the process of replacing its existing operating policies and planning standards, its current standards make little mention of load and its reliability function. Load is precluded from participating in ancillary services markets because generation is the only resource eligible to provide such services. ${ }^{22}$ Similarly, the procedures and policies of operators of the system often only reflect generation as a market participant. ${ }^{23}$

\section{Utility and System Operator Barriers}

As noted above, utilities and operators of the system have little incentive to undertake programs that can cut into their bottom line. They are paid to generate and transmit electricity and DR does neither. Thus there is a supply side bias for serving load. This contributes to a lack of experience with time variant pricing and the perception that the benefits of DR will not offset the costs. ${ }^{24}$ The cost and difficulty of retooling a company's billing functions to accommodate DR can also be a hurdle. ${ }^{25}$

\section{Customer Barriers}

Without price signals, customers cannot see the value in adjusting their electricity usage. Without knowledge of DR programs themselves, customers may have the perception that their energy bills will increase substantially or that business will suffer due to curtailments. They may fear that backup generation will be unavailable or that they will incur burdensome penalties for nonperformance. ${ }^{26}$ Metering and communications equipment can be cost prohibitive. Finally, customers just might not want to relinquish control of the operation of their facilities or put in the time and effort necessary to actively participate in a DR program. ${ }^{27}$

\footnotetext{
${ }^{19}$ Hirst and Kirby, Retail-Load Participation in Competitive Wholesale Electricity Markets 45 (2001).

${ }^{20}$ Messenger, supra note 15 , at 22.

${ }^{21}$ NPCC, supra note 3, at 5.

${ }^{22}$ CECA, Energy Security and Electric Industry Restructuring Forum 7 (2002).

${ }^{23}$ Hirst, Barriers to Price Responsive Demand in Wholesale Electricity Markets 10 (2002).

${ }^{24}$ Faruqui, "The Value of Dynamic Pricing in Mass Markets." The Electricity Journal July 2002 at 47.

${ }^{25}$ Messenger, supra note 15, at 22.

${ }^{26}$ Kathan, supra note 2, at 37.

${ }^{27}$ Id.
} 


\section{Technical Barriers}

Much as the regulation of the electric industry evolved around generation, so too did the technology. Some scheduling and dispatching software cannot accommodate bids from load, or do so only after optimizing supply bids. ${ }^{28}$ The various types of metering, communication and control equipment often require custom design of each project to enable interoperability with the program administrator. The cost of such project-byproject installation is harder to justify by LSEs and customers alike. Industry standards to ensure that different DR components work together would streamline project activation and lower costs. $^{29}$

\section{Demand Response Programs in the West}

Most of the large utilities in the West, whether they be investor owned, municipals, or quasi state entities supplying wholesale power like Salt River Project (AZ) or Platte River Power Authority (CO), offer some sort of demand response options for their customers. Operators of the system like Bonneville Power Administration and the California Independent System Operator also have several demand response offerings. California is the only state in the region to sponsor a specific demand response related program.

\section{A. Utility/ISO Demand Response Programs in the West}

Table 1 is a matrix of the demand response programs available to electric customers in the West. The entire report, Summary of Western States/Provinces

Demand Response Programs, complete with descriptions of specific programs, can be found in Appendix A. Programs in Table 1 are abbreviated as follows:

1. RTP - Real Time Pricing

2. TOU - Time of Use Pricing

3. DByBk - Demand Buyback

4. $\quad$ DBid - Demand Bidding

5. DLC - Direct Load Control

6. DSG - Dispatchable Standby Generation

7. INT - Interruptible

8. BOP - Black Out Protection

9. EDDR - Event Driven Demand Reduction

10. PDDR - Predetermined Demand Reduction

11. VC - Voluntary Curtailment

\footnotetext{
${ }^{28}$ Hirst, supra note 23.

${ }^{29}$ Hirst and Kirby, supra note 19, at 45.
} 
Table 1 - Western Demand Response Programs (September 2002)

\begin{tabular}{|c|c|c|c|c|c|c|c|c|c|c|c|c|}
\hline & Power agencies & $\begin{array}{l}1 \\
\text { RTP }\end{array}$ & $\begin{array}{l}2 \\
\text { TOU }\end{array}$ & $\begin{array}{l}3 \\
\text { DByBk }\end{array}$ & 4 & $D L C$ & $\begin{array}{l}6 \\
D S G\end{array}$ & $I N T$ & $B O P$ & $E D D R$ & $\begin{array}{l}10 \\
P D D R\end{array}$ & $\begin{array}{l}111 \\
V C\end{array}$ \\
\hline Alberta & Power Pool & 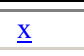 & 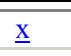 & & & & & & & & & $\underline{x}$ \\
\hline & & & & & & & & & & & & \\
\hline \multirow[t]{3}{*}{ Arizona } & Tucson Electric & & $\underline{\mathrm{x}}$ & & & & & $\underline{\mathrm{x}}$ & & & & \\
\hline & Salt River Project & & $\underline{\mathrm{x}}$ & & & & & $\underline{\mathrm{x}}$ & & & & \\
\hline & $\begin{array}{l}\text { Arizona Public } \\
\text { Service }\end{array}$ & & $\underline{\mathrm{x}}$ & & & & & & & & & \\
\hline & & & & & & & & & & & & \\
\hline \multirow[t]{2}{*}{$\begin{array}{l}\text { British } \\
\text { Columbia }\end{array}$} & BC Hydro & $\underline{\mathrm{x}}$ & $\underline{\mathrm{x}}$ & $\underline{\mathrm{x}}$ & & & & $\underline{\mathrm{x}}$ & & & $\underline{\mathrm{x}}$ & \\
\hline & UtiliCorp & & $\underline{\mathrm{x}}$ & & & & & & & & & \\
\hline & & & & & & & & & & & & \\
\hline \multirow[t]{11}{*}{ California } & Pacific Gas \& Elec & & $\underline{x}$ & & $\underline{x}$ & & & $\underline{x}$ & $\underline{x}$ & & & $\underline{x}$ \\
\hline & Sempra SDG\&E & & $\underline{\mathrm{x}}$ & & $\underline{\mathrm{x}}$ & & & $\underline{\mathrm{x}}$ & $\underline{\mathrm{x}}$ & & & $\underline{\mathrm{x}}$ \\
\hline & Southern Cal Edison & $\underline{\mathrm{x}}$ & $\underline{\mathrm{x}}$ & & $\underline{\mathrm{x}}$ & & & $\underline{\mathrm{x}}$ & $\underline{\mathrm{x}}$ & $\underline{\mathrm{x}}$ & & \\
\hline & California ISO & & & & & & & $\underline{\mathrm{x}}$ & $\underline{\mathrm{x}}$ & & & $\underline{\mathrm{x}}$ \\
\hline & LADWP & & $\underline{\mathrm{x}}$ & & & & & & & & & \\
\hline & Pasadena W\&P & & & & & & & & & & & $\underline{\mathrm{x}}$ \\
\hline & Sacramento MUD & & $\underline{\mathrm{x}}$ & $\underline{\mathrm{x}}$ & & $\underline{\mathrm{x}}$ & & & & & & $\underline{\mathrm{x}}$ \\
\hline & Vernon Munic Light & & $\underline{\mathrm{x}}$ & & & & & & & & & \\
\hline & PacifiCorp & & $\underline{\mathrm{x}}$ & & & & & & & & & \\
\hline & Silicon Valley Elec. & & & & & & & & $\underline{\mathrm{x}}$ & & & \\
\hline & $\begin{array}{l}\text { California Energy } \\
\text { Commission }\end{array}$ & $\underline{\mathrm{x}}$ & & & & & & & & & & $\underline{x}$ \\
\hline & & & & & & & & & & & & \\
\hline & & & & & & & & & & & & \\
\hline \multirow[t]{2}{*}{ Colorado } & Xcel Energy & $\underline{\mathrm{x}}$ & $\underline{\mathrm{x}}$ & & & & & $\underline{\mathrm{x}}$ & & & & $\underline{\mathrm{x}}$ \\
\hline & $\begin{array}{l}\text { Platte River Power } \\
\text { Authority }\end{array}$ & & & & & & & & & & $\underline{\mathrm{x}}$ & \\
\hline & & & & & & & & & & & & \\
\hline & & & & & & & & & & & & \\
\hline \multirow[t]{4}{*}{ Idaho } & Idaho Power & & $\underline{\mathrm{x}}$ & $\underline{\mathrm{x}}$ & & & & & & & $\underline{\mathrm{x}}$ & \\
\hline & PacifiCorp & & $\underline{\mathrm{x}}$ & $\underline{\mathrm{x}}$ & & & & $\underline{\mathrm{x}}$ & & & & $\underline{\mathrm{x}}$ \\
\hline & $\begin{array}{l}\text { Bonneville Power } \\
\text { Administration }\end{array}$ & & & $\underline{x}$ & & & & & & & & \\
\hline & Avista & & & $\underline{\mathrm{x}}$ & & & & & & & & \\
\hline \multirow[t]{2}{*}{ Montana } & $\begin{array}{l}\text { Bonneville Power } \\
\text { Administration }\end{array}$ & & & $\underline{\mathrm{x}}$ & & & & & & & & \\
\hline & Montana Power & & $\underline{\mathrm{x}}$ & & & & & & & & & \\
\hline & & & & & & & & & & & & \\
\hline \multirow[t]{2}{*}{ Nevada } & Nevada Power & & $\underline{x}$ & & & & & $\underline{\mathrm{x}}$ & & & & $\underline{\mathrm{x}}$ \\
\hline & Sierra Pacific & & $\underline{\mathrm{x}}$ & & & & & $\underline{\mathrm{x}}$ & & & & $\underline{\mathrm{x}}$ \\
\hline
\end{tabular}




\begin{tabular}{|c|c|c|c|c|c|c|c|c|c|c|c|c|}
\hline & Power agencies & $\begin{array}{l}1 \\
\text { RTP }\end{array}$ & $\begin{array}{l}2 \\
\text { TOU }\end{array}$ & $\begin{array}{l}3 \\
\text { DByBk }\end{array}$ & $\begin{array}{l}4 \\
\text { DBid }\end{array}$ & $\begin{array}{l}5 \\
D L C\end{array}$ & $\begin{array}{l}6 \\
D S G\end{array}$ & $I N T$ & $\begin{array}{l}8 \\
B O P\end{array}$ & $\begin{array}{l}9 \\
\text { EDDR }\end{array}$ & $\begin{array}{l}1 \quad 0 \\
P D D R\end{array}$ & $\begin{array}{l}111 \\
V C\end{array}$ \\
\hline & & & & & & & & & & & & \\
\hline \multirow[t]{2}{*}{$\begin{array}{l}\text { New } \\
\text { Mexico }\end{array}$} & New Mexico PSC & & $\underline{\mathrm{x}}$ & & & & & & & & & \\
\hline & TNP Enterprises & & $\underline{\mathrm{x}}$ & & & & & $\underline{\mathrm{x}}$ & & & & \\
\hline & & & & & & & & & & & & \\
\hline & & & & & & & & & & & & \\
\hline \multirow[t]{7}{*}{ Oregon } & Portland GE & $\underline{\mathrm{x}}$ & $\underline{\mathrm{x}}$ & $\underline{\mathrm{x}}$ & & & $\underline{\mathrm{x}}$ & & & & & \\
\hline & PacifiCorp & $\underline{\mathrm{x}}$ & $\underline{\mathrm{x}}$ & $\underline{\mathrm{x}}$ & & & & & $\underline{\mathrm{x}}$ & & & $\underline{\mathrm{x}}$ \\
\hline & $\begin{array}{l}\text { Bonneville Power } \\
\text { Administration }\end{array}$ & & & $\underline{x}$ & & & & & & & & \\
\hline & Columbia River PUD & & & & & & & & & & & $\underline{\mathrm{x}}$ \\
\hline & Idaho Power & & & $\underline{\mathrm{x}}$ & & & & & & & & \\
\hline & $\begin{array}{l}\text { Eugene Water \& } \\
\text { Electricity Board }\end{array}$ & & & $\underline{x}$ & & & & & & & & \\
\hline & $\begin{array}{l}\text { Springfield Utility } \\
\text { Board }\end{array}$ & & & $\underline{x}$ & & & & & & & & \\
\hline & & & & & & & & & & & & \\
\hline $\begin{array}{l}\text { Saskat- } \\
\text { chewan }\end{array}$ & SaskPower & & $\underline{x}$ & & & & & & & & & \\
\hline & & & & & & & & & & & & \\
\hline Utah & PacifiCorp & & $\underline{\mathrm{x}}$ & $\underline{\mathrm{x}}$ & & & & $\underline{\mathrm{x}}$ & & & & $\underline{\mathrm{x}}$ \\
\hline & & & & & & & & & & & & \\
\hline & & & & & & & & & & & & \\
\hline \multirow[t]{5}{*}{ Washington } & Puget Sound Energy & & $\underline{\mathrm{x}}$ & $\underline{\mathrm{x}}$ & & & & & & & & \\
\hline & PacifiCorp & & & $\underline{\mathrm{x}}$ & & & & & & & & $\underline{\mathrm{x}}$ \\
\hline & $\begin{array}{l}\text { Bonneville Power } \\
\text { Administration }\end{array}$ & & & $\underline{\mathrm{x}}$ & & & & & & & & \\
\hline & Avista & & & $\underline{\mathrm{x}}$ & & & & & & & & \\
\hline & Grant County PUD & & & $\underline{\mathrm{x}}$ & & & & & & & & \\
\hline & & & & & & & & & & & & \\
\hline Wyoming & PacifiCorp & & & $\underline{x}$ & & & & & & & & \\
\hline & & & & & & & & & & & & \\
\hline
\end{tabular}

\section{B. State Sponsored Demand Response Related Programs in the West}

California is the only state in the West to directly sponsor DR related programs. The California Energy Commission offers customers two options. The Real-Time Meter Installation Program has funded the installation of interval meters and appropriate communications links at 23,375 customer facilities having a peak demand of $200 \mathrm{~kW}$ or higher. The goal of the program was to install the metering infrastructure necessary for customers to participate in load reduction/curtailment programs during the summer of 2001. As a result, commercial and industrial customer classes would also be prepared to 
participate in real-time electricity pricing. Total project cost was $\$ 34$ million and estimates of peak reductions range from 400 to $700 \mathrm{MW}$, depending on the rates and price signals available to customers.

In the Cash for Kilowatts Program, customers or aggregators are provided cash incentives of up to $\$ 150 / \mathrm{kW}$ of capacity reduction pledged to install interval meters and communication equipment necessary to respond to requests for reductions from the California Independent Systems Operator or utility distribution companies (UDCs). Customer response is voluntary, depending on whether they signed up for any pay for capacity or demand response programs. Over 300 customers installed systems and provided roughly $200 \mathrm{MW}$ of demand reduction capability for the summer of 2001.

\section{Lessons for States/Provinces}

\section{A. Results of State Survey}

Western states/provinces have had varied success implementing DR programs within their own jurisdictions. Several of the barriers identified earlier in this report came into play. California achieved the most load reduction, on account of customer response to the traumatic experiences of 2000-2001 and tens of millions of dollars in state funding for DR related programs. Below is a summary of state feedback to questions on the implementation of DR programs. Individual responses can be found in Appendix B.

Much of DR's success in the West is determined by the nature of a state's electricity markets. Utilities in states with robust wholesale markets (AZ) were less likely to employ DR for load reductions because electricity prices remained relatively stable. There was also less enthusiasm for DR in states with extensive hydro resources (WA) since LSEs relied less on open market spot purchases. States with regulated retail markets (NM, CO) were less supportive of DR since resource planning rules required adequate resources to serve load and price differentials between peak and off-peak power were less pronounced. States which are net importers of energy and rely on the spot market to meet peak load (NV) acknowledged the value of DR.

Western state experience with DR exposed the difficulty in designing programs and rate structures to accomplish the goals of the utility while satisfying customers' desires for simplicity. Utilities exhibited a sort of cultural obstinacy against DR based upon fear of lost revenues. PUCs had trouble structuring tariffs so that rate of return regulations were satisfied. In certain instances, the level of load reduction incentives seemed too high when considering how much customers might reduce for free if exposed to dynamic pricing. Some TOU programs were criticized because meter reading was out of sync with monthly variable rates, making it harder for customers to see the benefits of responding to TOU signals. Also, it proved difficult to set TOU prices to accurately reflect market prices.

The state DR survey provided insights on customer preferences. It was clear that customers are more willing to participate in a DR program when there's an appreciable 
difference between on and off-peak rates and when they have the option to participate on a per-event basis. Customers are less likely to participate if buy-back incentives are too low or the time period too short. One state reported that interruptible and load reduction programs were more popular than dynamic pricing programs because customers could see the benefits in the form of a check or discounts. The issue of whether benefits outweighed costs was a constant.

\section{B. Findings of Other Research Efforts}

Several efforts have been made to evaluate the success of actual DR programs. ${ }^{30}$ These reports have fairly consistent findings, many of which are born out in the state responses noted above. Below is a summary of observations other have made in gauging the effectiveness of DR.

\section{Nature of Electric Markets}

- Low wholesale prices prevent program administrators from being able to offer attractive incentives for load reductions thus dampening participation in wholesale DR programs.

\section{Regulatory Considerations}

- It's important to consider cost recovery issues at the retail state/provincial level as utility distribution companies (UDCs) are at risk of losing revenue when customers participate in ISO sponsored DR programs.

- Coordination between operators of the system and UDCs/LSEs facilitates customer participation in DR programs. For example, a PUC requirement that all UDC/LSEs file tariffs implementing ISO programs helps reduce customer confusion and provides a means for the aggregation of customer load.

\section{Program Design}

- The success of DR programs depends, among other things, on the simplicity of the program, the simplicity of the customer baseline calculation, the level of customer education and the range of offerings.

- Significant financial incentives (\$150-200 per MWh) are required to obtain sizable customer market response. Companies should disburse payments with little delay (e.g., by end of next metering cycle subject to adjustment).

\footnotetext{
${ }^{30}$ See Lutzenhiser, Understanding the Response of Commercial and Institutional Organizations to the California Energy Crisis (2002); Kathan, Policy and Technical Issues Associated With ISO Demand Response Programs (2002); Rosenfeld et al., Dynamic Pricing, Advanced Metering and Demand Response in Electricity Markets (2002); Goldman et al., Customer Load Participation in Wholesale Markets: Summer 2001 Results, Lessons Learned and "Best Practices" (2002); and Hirst and Kirby, Retail-Load Participation in Competitive Wholesale Electricity Markets (2001)
} 
- DR programs should be designed and approved well before summer to minimize customer confusion, allow time for them to train on rules and invest in metering/communication technology.

- Paying customers for their capability to reduce demand and not just for actual energy reductions contributes to the success of a program. Fixed capability payments along with energy payments give customers greater certainty of the return from their participation.

- Dynamic pricing tariffs show much larger changes in usage than do traditional TOU rates, especially when combined with enabling technology like 2-way communication and programmable/controllable thermostats. But, in states with deregulation, RTP isn't as popular given the potential for price fluctuations.

\section{Customer Factors}

- Many industrial customers are already involved with DR programs such as interruptible rates. Greater participation from commercial and institutional customers is critical if DR is to achieve its full potential.

- Certain types of customers are more likely to shift load than others, particularly those with on-site generation, those with high energy costs as a percentage of total costs, those with non-continuous production processes and those who have had previous experience with interruptible rates.

- Demand for electricity under TOU is inelastic in the short run so programs should be of sufficient duration. Price elasticities for residential consumers are larger than for small to medium sized commercial and industrial consumers.

- Trade associations and similar groups that firms are involved in play a role in the energy decisions organizations make. Public and private entities alike tend to use peers, competitors and trade groups as sources of information and models for action. Public opinion can also play a role in spurring participation in DR and conservation programs.

\section{Recommendations for States/Provinces}

There is much that could be done to encourage DR. ISOs and LSEs could streamline program application processes. Wholesale markets could open ancillary service markets to demand-side resources. Manufacturers of enabling technology could pursue advances in metering and communications equipment to improve the interoperability of components. This report, however, is focused on states/provinces and their experience with DR. Below are suggestions of steps states/provinces can take to encourage DR, many of which call for further research and rulings on the part of state PUCs. 
States/provinces should set goals for load reductions (MW) and support the widespread use of demand response (DR) to help ensure grid reliability and promote economic efficiency in the consumption of electricity. States/provinces should help load serving entities (LSEs) educate customers about how demand response works and how they can benefit from such programs. States/provinces should seek to ensure consistency in program funding and long term program operation to make it easier for organizations to plan and participate in DR. ${ }^{31}$

Demand Response programs themselves should be available to all customer classes and come in a wide variety of easy to understand formats. Programs should feature load reduction capability payments for participation, in addition to energy payments for actual reductions. Programs should also accurately measure the savings achieved. This gives customers a clear view of the benefits to be achieved thus encouraging participation and increasing customer retention.

States/provinces should address the jurisdictional complexities posed by DR programs in both wholesale and retail market. Demand response is a central theme in FERC's effort to standardize the bulk trade of electricity. State inaction on DR may result in some loss of control over the role these resources play in residents' energy decisions. It is the responsibility of states/provinces to ensure that benefits provided by DR at the wholesale level are realized at the retail level. ${ }^{32}$ PUCs should ensure that retail DR programs are coordinated with ISO programs (e.g., ensure that state policies and UDC tariffs are consistent with ISO market design). PUCs should work together with FERC, operators of the system, UDCs and LSEs to address barriers and encourage DR.

States/provinces should consider a move away from standard-offer default retail electric rates based on pre-determined customer class average load profiles and subject to rate caps. Such rate structures offer customers little incentive to adjust electricity usage. Alternative load profiles reflecting the control of known load components (e.g., residential hot water heaters and air conditioners) should be developed to encourage price responsive load management. ${ }^{33}$ Buy-back rates should be deaveraged to reflect the true marginal costs of delivering power during peak demand periods and/or over congested portions of the grid. And time differentiated price caps featuring meaningful differences between peak and off-peak consumption should be approved. ${ }^{34}$

States/provinces can undertake even more comprehensive measures to facilitate DR including mandating the use of interval meters and time-variant pricing by all customer classes. One step further would be to adopt a performance-based regulation regime in which LSEs are granted cost recovery based on efficiency of operations rather than system throughput. A revenue cap approach is generally recommended wherein a PUC

\footnotetext{
${ }^{31}$ Lutzenhiser, Understanding the Response of Commercial and Institutional Organizations to the California Energy Crisis viii (2002).

${ }^{32}$ Kathan, supra note 2, at 49.

${ }^{33}$ Hirst and Kirby, supra note 19 , at 42-43)

${ }^{34}$ Cowart, supra note 16 , at 58 .
} 
sets a per-customer revenue cap for recovery over a predetermined time period and the utility keeps whatever savings it reaps from reliably serving customers in an efficient manner. ${ }^{35}$

To facilitate approval and cost recovery for DR programs, state PUCs should rule on several unresolved issues critical to the operation of DR. PUCs should specify who will install and own advanced metering, communications and control equipment and who will have access to the data generated. PUCs should ensure fair cost recovery for distribution companies and LSEs participating in wholesale DR programs as significant levels of DR can cut into revenues under cost-of-service regulation. The calculation of customer baseline loads should be standardized to avoid issues of customers "gaming" DR programs. And PUCs should undertake research to assess the costs, benefits and value of DR for use in ratemaking proceedings. ${ }^{36}$

${ }^{35}$ Cowart, supra note 16 , at 61.

${ }^{36}$ Messenger, supra note 15 , at 27-30. 


\section{References}

Association of Energy Service Professionals. Peak Load Management or Demand Response Programs: A Policy Review. August 2001.

Braithwait, S. and Eakin, K. The Role of Demand Response in Electric Power Market Design. Edison Electric Institute, October 2002.

Consumer Energy Council of America. Energy Security and Electric Industry Restructuring Forum. July 2002.

Cowart, R. Efficient Reliability - The Critical Role of Demand-Side Resources in Power Systems and Markets. National Association of Regulatory Utility Commissioners, June 2001.

Eto, J., Goldman, C. and Nadel, S. Ratepayer Funded Energy-Efficiency Programs in a Rstructured Electricity Industry: Issues and Options for Regulators and Legislators. Energy Analysis Department, Environmental Energy Technologies Division, Ernest Orlando Lawrence Berkeley National Laboratory, May 1998.

Faruqui, A. and George, S. "The Value of Dynamic Pricing in Mass Markets.” The Electricity Journal July 2002: 45-55.

Gilligan, D. “Grading 2001's ISO Demand Response Programs.” Energy User News November 2001: 12-14.

Goldman, C. Framing Paper \#1: Price Responsive Load (PRL) Programs. New England Demand Response Initiative, March 2002.

Goldman, C., Eto, J. and Barbose, G. California Customer Load Reductions during the Electricity Crisis: Did They Help to Keep the Lights On? Energy Analysis Department, Environmental Energy Technologies Division, Ernest Orlando Lawrence Berkeley National Laboratory, May 2002.

Goldman, C., Heffner, G. and Barbose, G. Customer Load Participation in Wholesale Markets: Summer 2001 Results, Lessons Learned and “Best Practices”. Energy Analysis Department, Environmental Energy Technologies Division, Ernest Orlando Lawrence Berkeley National Laboratory, February 2002.

Hirst, E. and Kirby, B. Retail-Load Participation in Competitive Wholesale Electricity Markets. Edison Electric Institute and Project for Sustainable FERC Energy Policy, January 2001.

Hirst, E. Barriers to Price Responsive Demand in Wholesale Electricity Markets. Edison Electric Institute, June 2002. 
Hirst, E. Price-Responsive Demand as Reliability Resources. April 2002.

Kathan, D. Policy and Technical Issues Associated With ISO Demand Response

Programs. National Association of Regulatory Utility Commissioners, July 2002.

Lutzenhiser, L. Understanding the Response of Commercial and Institutional Organizations to the California Energy Crisis. California Energy Commission, July 2002.

Messenger, M. A Proposed Action Plan to Develop More Demand Response in California’s Electricity Markets. California Energy Commission, April 2002.

"New Principles for Demand Response Planning." EPRI Journal Online $<$ http://www.epri.com/journal/details.asp?doctype $=$ discovery\&id $=423>$.

Northwest Power and Conservation Council. Demand Response - Issue Paper in Preparation for the $5^{\text {th }}$ Power Plan. $<$ http://www.nwcouncil.org/library/2002/2002$\underline{18 . h t m}>$ December 2002.

Peak Load Management Alliance. Demand Response: Principles for Regulatory Guidance. February, 2002.

Prindle, W. et al. Energy Efficiency's Next Generation: Innovation at the State Level. American Council for an Energy-Efficient Economy. November 2003.

Rosenfeld, A., Jaske, M. and Borenstein, S. Dynamic Pricing, Advanced Metering and Demand Response in Electricity Markets. The Energy Foundation, October 2002.

The Regulatory Assistance Project. "Using a Demand Response to Stabilize Electric Markets.” RAP Issuesletter February 2001.

Weston, F. and Lazar, J. Framing Paper \#3: Metering and Retail Pricing. New England Demand Response Initiative, May 2002. 


\section{Appendix A}

\section{Western Interstate Energy Board}

\section{Summary of Western States/Provinces Demand Response Programs}

(revised 9/26/02)

This research was supported in part by a grant from the U.S. Department of Energy (Grant Number DE-FG03-01SF22369) to the Western Interstate Energy Board. Such financial support does not constitute an endorsement by DOE of the views expressed in this report. 


\section{TABLE OF CONTENTS}

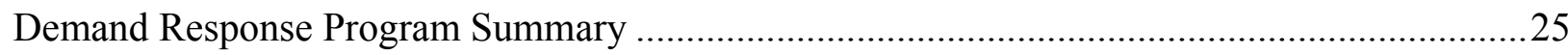

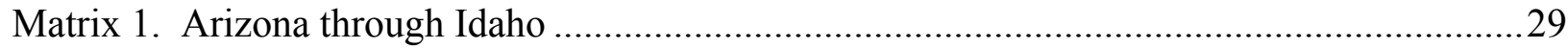

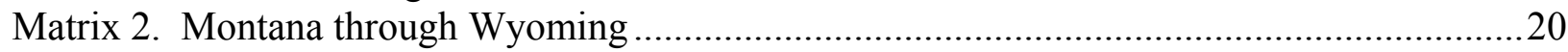

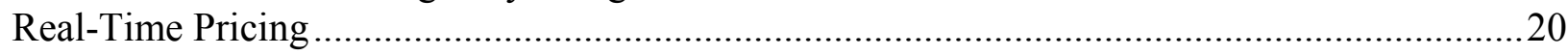

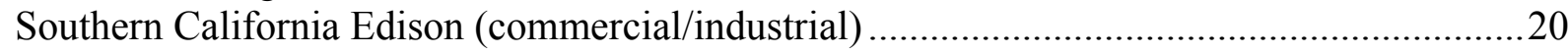

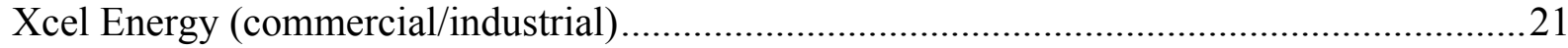

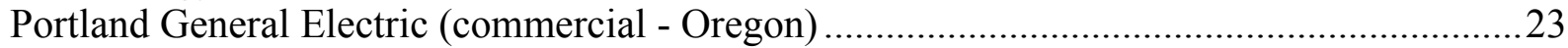

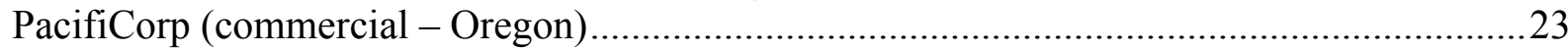

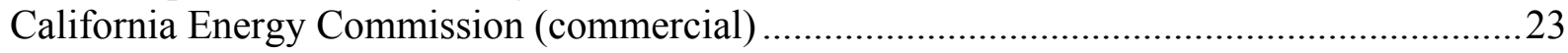

California Energy Commission (infrastructure) .................................................................2

British Columbia Hydro \& Power Authority (CANADA) (commercial/industrial) .................24

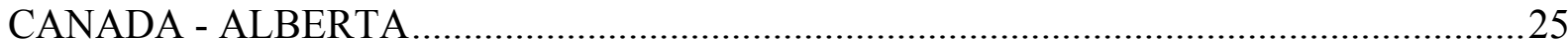

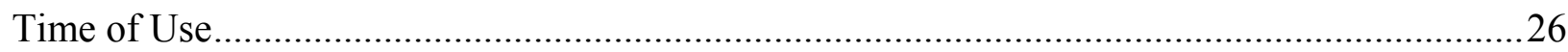

Los Angeles Department of Water and Power (commercia/industrial) ..................................26

Los Angeles Department of Water and Power (residential) ....................................................2.

Vernon California Municipal Light (commercial/industrial)...................................................2

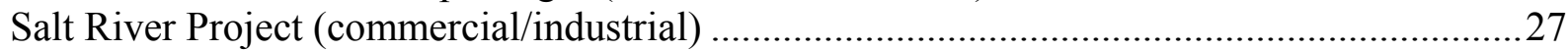

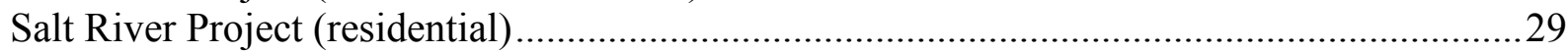

Southern California Edison (commercial/industrial) ……......................................................2

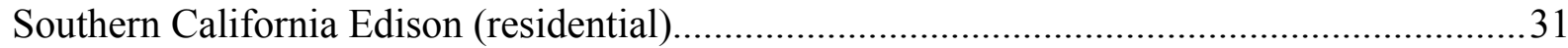

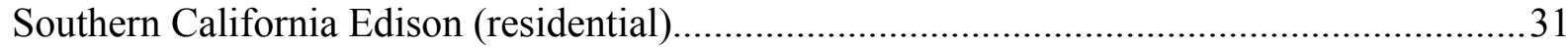

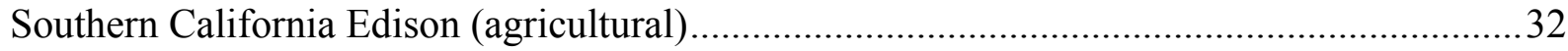

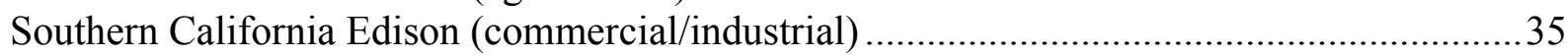

Sempra San Diego Gas \& Electric (commercial/industrial) ....................................................... 36

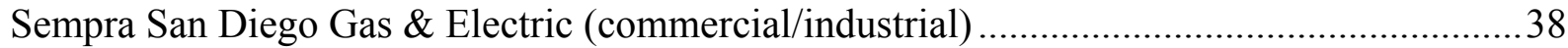

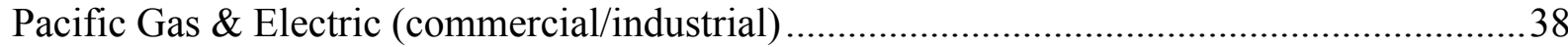

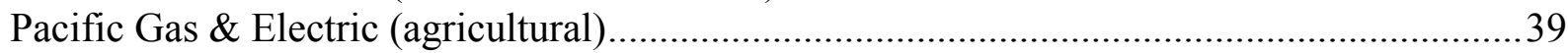

Pacific Gas \& Electric (commercial/industrial) ...................................................................... 41

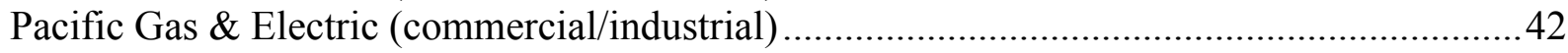

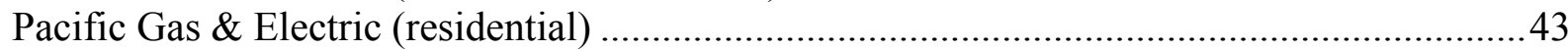

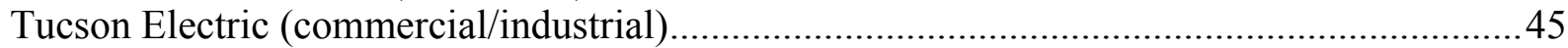

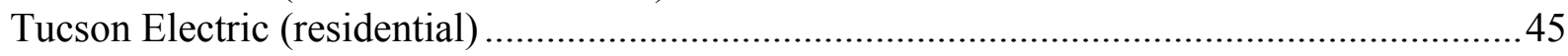

Portland General Electric (commercial/industrial) ...............................................................4 46

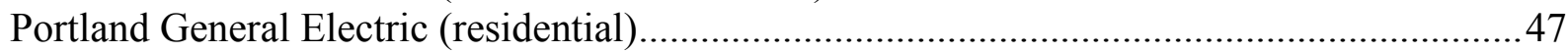

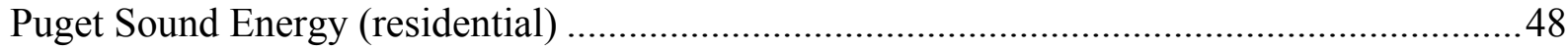

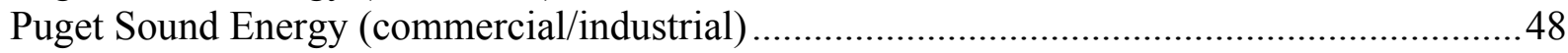

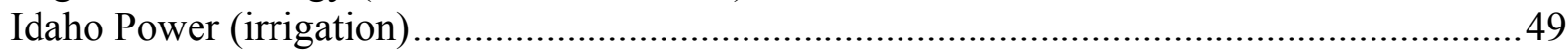

Sacramento Municipal Utility District (commercial/industrial) ..............................................50

Texas-New Mexico Power Company (commercial/industrial) ……….....................................52

Xcel Energy (residential) ............................................................................................. 52

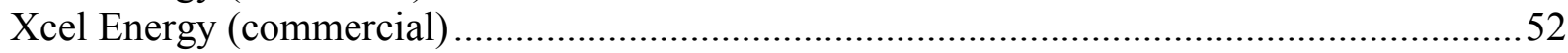

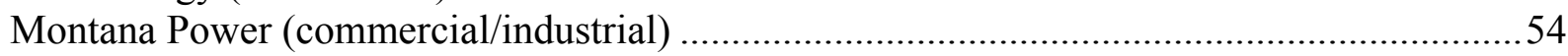

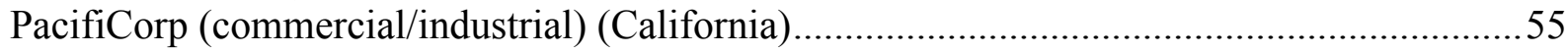

PacifiCorp (Utah Power \& Light) (commercial/industrial)(Idaho) ............................................55 
PacifiCorp - Utah Power \& Light (Idaho) (residential) ...............................................56

PacifiCorp - Utah Power \& Light (Utah) (residential) .....................................................56

PacifiCorp - Utah Power \& Light (Utah) (residential) .........................................................5 57

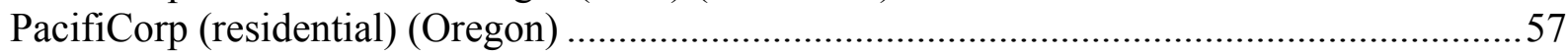

New Mexico Public Service Company (residential)........................................................5

New Mexico Public Service Company (commercial/industrial) ........................................5 58

New Mexico Public Service Company (government) .....................................................5

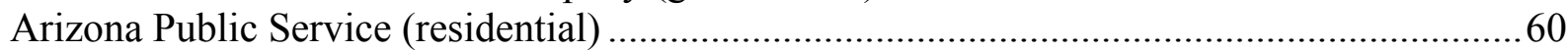

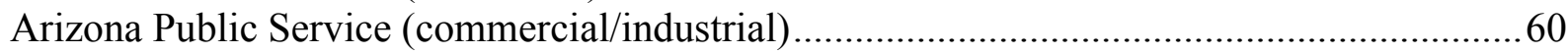

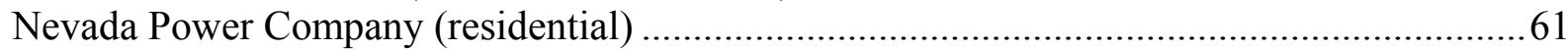

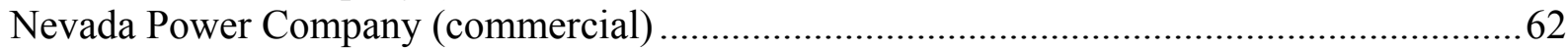

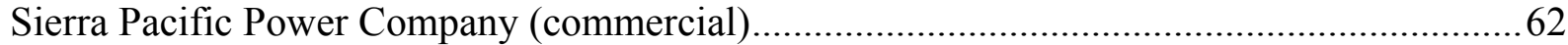

British Columbia Hydro \& Power Authority (CANADA) (commercial/industrial) ................64

British Columbia Hydro \& Power Authority (CANADA) (commercial/industrial) ...............65

Aquila Networks Canada (British Columbia) Ltd. (time-of-use-pricing)..............................65

Aquila Networks Canada (British Columbia) Ltd. (residential tou) .......................................66

Aquila Networks Canada (British Columbia) Ltd. (commercial/industrial)..........................66

Aquila Networks Canada (British Columbia) Ltd. (commercial/industrial)...........................67

Aquila Networks Canada (British Columbia) Ltd. (commercial/industrial)..........................67

Aquila Networks Canada (British Columbia) Ltd. (commercial/industrial)..........................6 68

Aquila Networks Canada (British Columbia) Ltd. (commercial/industrial)..........................66

Aquila Networks Canada (British Columbia) Ltd. (agricultural) .........................................69

SaskPower (Saskatchewan, CANADA) (commercial) .......................................................69

SaskPower (Saskatchewan, CANADA) (commercial) ...................................................... 70

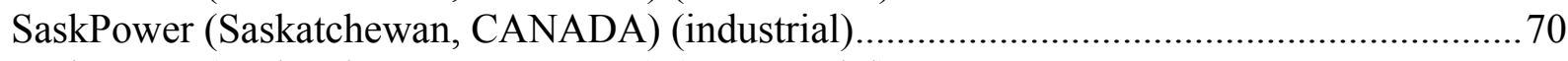

SaskPower (Saskatchewan, CANADA) (commercial) ................................................... 71

SaskPower (Saskatchewan, CANADA) (commercial) ........................................................ 72

SaskPower (Saskatchewan, CANADA) (industrial)........................................................... 72

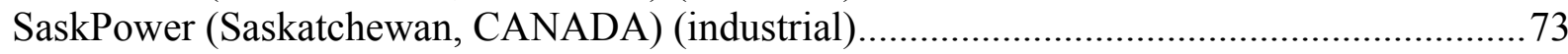

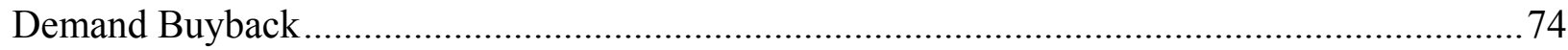

Sacramento Municipal Utility District (commercial/industrial) ..................................... 74

Portland General Electric (commercial/industrial) ....................................................... 74

Bonneville Power Administration (commercial/industrial) .............................................. 75

Bonneville Power Administration (commercial/industrial) .............................................. 75

Eugene Water and Electric Board (commercial/industrial) .............................................. 75

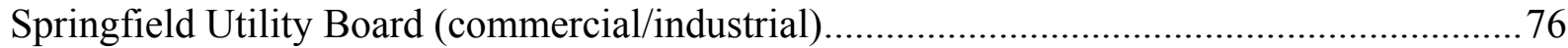

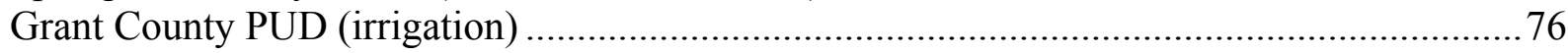

Puget Sound Energy (commercial/industrial) .......................................................... 76

Puget Sound Energy (commercial/residential) ........................................................... 78

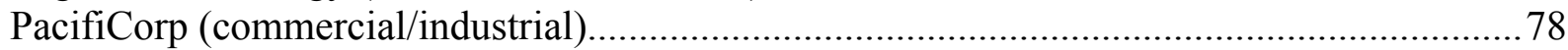

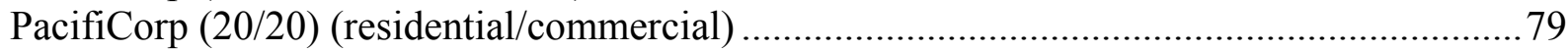

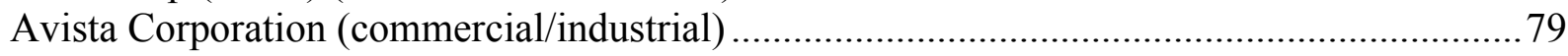

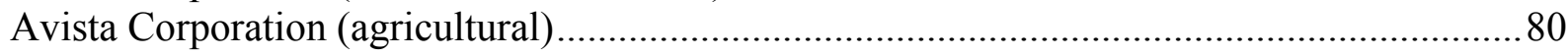

Avista Corporation (residential/commercial/industrial) ............................................. 80

Avista Corporation (residential/commercial/industrial) ................................................ 80

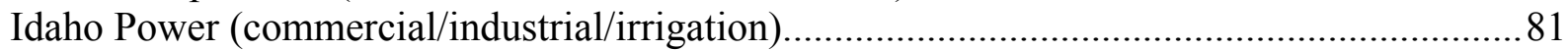

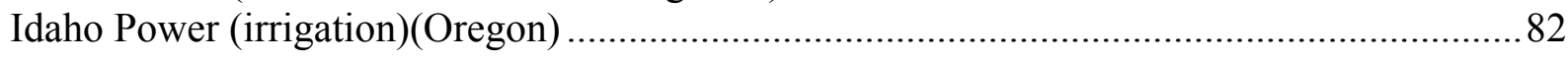


British Columbia Hydro \& Power Authority (CANADA) (commercial/industrial buy-back) 82

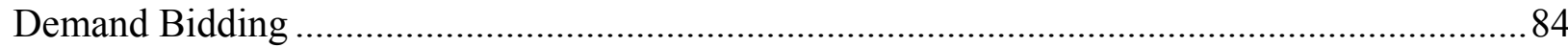

Southern California Edison (commercial/industrial) ....................................................... 84

Sempra San Diego Gas \& Electric (commercial/industrial) ............................................ 84

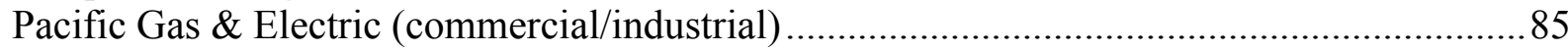

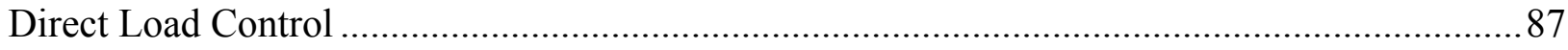

Sacramento Municipal Utility District (commercial/industrial) …...................................8 87

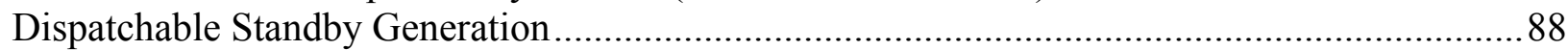

Portland General Electric (commercial/industrial) ....................................................... 88

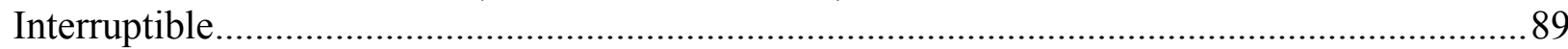

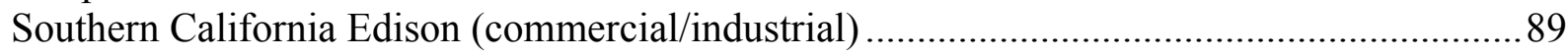

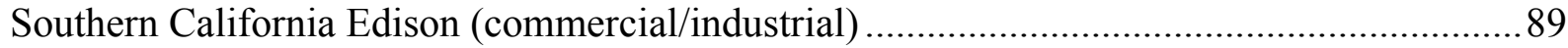

Pacific Gas and Electric (commercial/industrial) ...................................................... 90

Xcel Energy (commercial/industrial) ......................................................................... 90

PacifiCorp - Utah Power \& Light (State of Idaho) (commercial/industrial)......................... 92

PacifiCorp (State of Utah) (industrial) ........................................................................... 93

Texas-New Mexico Power Company (commercial/industrial) ........................................... 93

Sempra San Diego Gas \& Electric (commercial/industrial) ............................................... 95

California Independent Systems Operator (CAISO) (commercial) .................................... 95

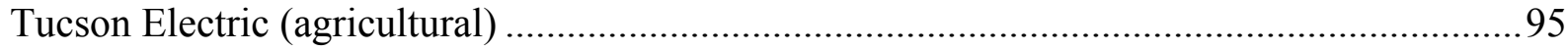

Sierra Pacific Power Company (commercial) .............................................................. 96

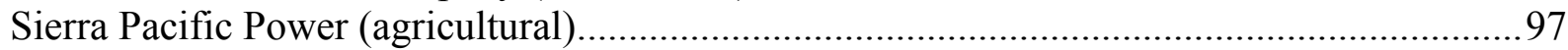

Nevada Power Company (agricultural)......................................................................... 97

British Columbia Hydro \& Power Authority (commercial/industrial) ................................. 98

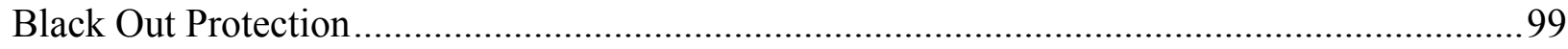

Southern California Edison (commercial/industrial) ........................................................ 99

Pacific Gas and Electric (commercial/industrial) ........................................................... 99

Sempra San Diego Gas \& Electric (commercial/industrial) ............................................... 99

California Independent Systems Operator (CAISO) (commercial) .................................. 100

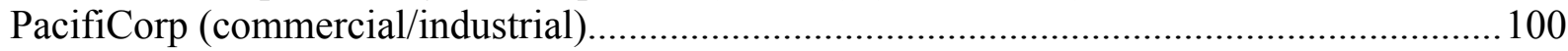

Silicon Valley Power (commercial/industrial)....................................................... 100

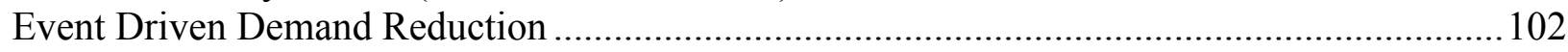

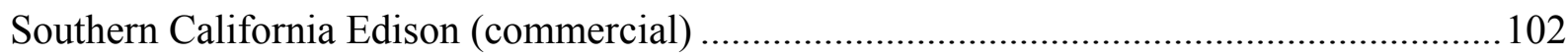

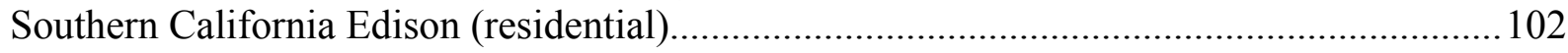

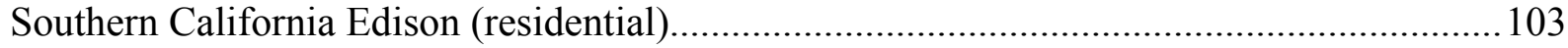

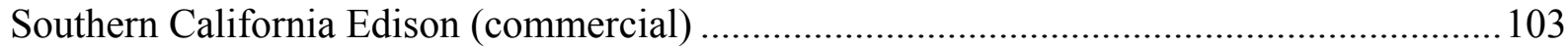

Southern California Edison (commercial/industrial) ............................................... 105

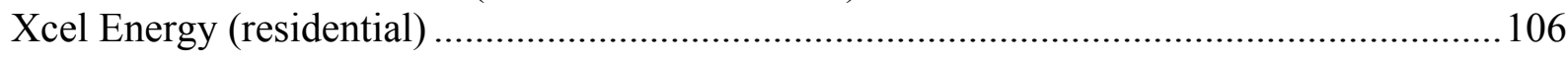

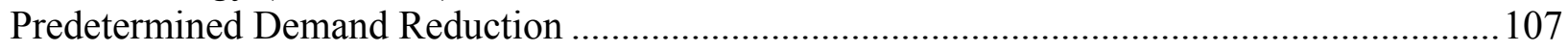

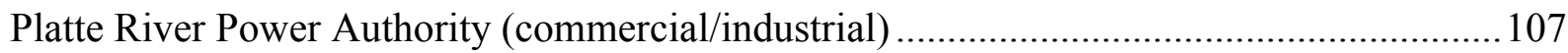

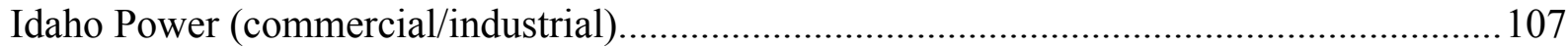

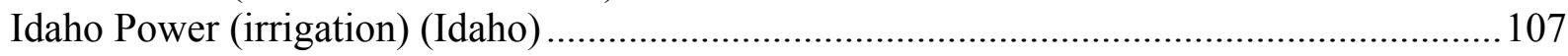

British Columbia Hydro \& Power Authority (CANADA)(commercial/industrial) .............. 108

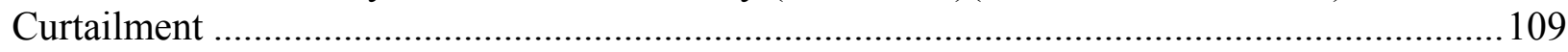

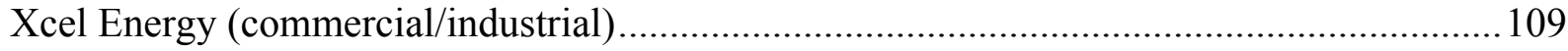

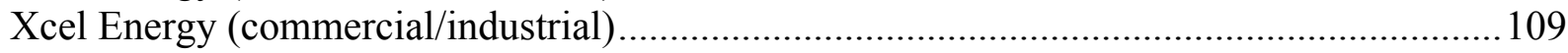

Pasadena Water and Power (commercial/industrial) ................................................... 111 


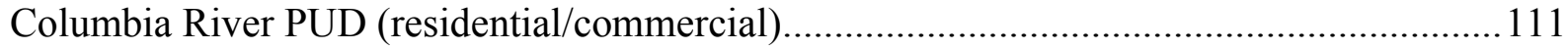

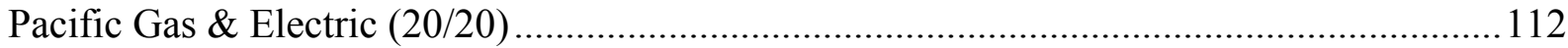

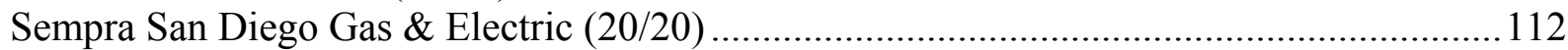

Sacramento Municipal Utility District (commercial/industrial) ......................................... 112

California Independent Systems Operator (CAISO) (commercial/industrial)...................... 113

California Energy Commission (commercial) ........................................................... 113

PacifiCorp PowerForward Program (Utah) (commercial/residential) ................................. 114

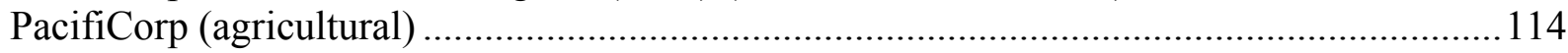

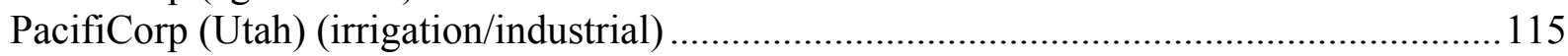

Sierra Pacific Power Company (commercial) ............................................................. 115

Nevada Power Company (commercial) ...................................................................... 116 
The following demand response program summary was initially prepared for discussions of Western states and provinces at the May 2002 meeting of the Committee on Regional Electric Power Cooperation. This newer version of the summary includes corrections and additions from the meeting as well as information submitted after the meeting.

\section{Demand Response Program Summary}

Sharon Irwin, Eric Waeckerlin

Following is background information on:

- The approach we used to identify and summarize demand response programs;

- A matrix showing which utilities have which types of demand response programs (the matrix is hyperlinked to the programs so you can quickly get to your utilities' programs);

- Brief descriptions of each program reviewed.

\section{Approach Used to Generate the Summary Information}

We defined demand response programs as programs designed to primarily reduce electricity use during peak usage periods, either directly (interruptible) or indirectly (real-time pricing) or bring on-line customer generation. We included both residential and commercial/industrial demand-response programs. We excluded programs that are primarily designed to promote use of renewable energy (solar, wind, geothermal, hydro etc.) and overall energy efficiency.

We derived most of the information in the analysis from company web sites.

\section{Reasons to Examine Demand Response Programs}

Several benefits are attributable to demand response programs including:

- Reducing the cost of maintaining and procuring operating reserves;

- Increasing system reliability during peak times at a lower cost to the utility;

- Mitigating price spikes;

- Mitigating the exercise of market power;

- Sending consumers better price signals to enable them to make wiser choices on electricity use; and

- Shifting the "insurance premiums" consumers currently pay as part of a flat rate to guarantee reliability, from a social allocation basis where the insurance premium is included in everyone's rate structure to a market driven basis where payment differs 
based on individual usage. ${ }^{37}$ One net benefit of this shift in insurance premiums is a reduction in rates benefiting all customers, whether they continue to pay a flat rate or not.

In addition to these general benefits from demand response, there are several specific reasons why the West needs to pursue demand response programs:

- Western Governors have urged the adoption of more timely and accurate price signals to consumers to enable consumers to make wise decisions on the time and amount of electricity consumed. The WGA Conceptual Plans for Electricity Transmission in the West identified demand management as a potential cost-effective alternative to some transmission line expansion.

- References to demand response are ubiquitous throughout FERC's "Working Paper on Standardized Transmission Service and Wholesale Market Design," and will likely play a significant role in the operation of day-ahead energy markets, operating reserve markets, and structural market power monitoring efforts in FERC's rule on standard market design.

- Ambiguity exists regarding FERC's jurisdictional authority over demand response programs. It is important that Western states be active in demand response to avoid potential jurisdictional disputes or leave a policy vacuum that FERC will try to fill with standardized programs that may not fit conditions in each state or region.

- Demand response is a significant alternative that needs to be part of any proactive regional transmission planning. Demand response options can provide substantial environmental, financial, reliability and congestion benefits.

${ }^{37}$ Under demand response programs, individual customers who value and use their electricity differently are able manage their own "insurance premium" risk level through participation in various programs (real-time pricing, time of use etc.), thus eliminating the portion of their payment currently used to provide financial insurance (a flat rate everyone pays where part of that rate goes to pay for reliability "insurance" or the maintenance of operating reserves). The consumer shifts electricity usage, effectively replacing the payment for a "reliability insurance premium" they used to pay under the old "flat-rate" system with an insurance premium amount derived solely from their usage under the program. This is a "risk" shift that benefits individual consumers in the form of lower electricity bills, as well as all consumers in the form of lower electricity rates. This concept is taken from Eric Hirst's paper entitled "The Financial and Physical Insurance Benefits of Price-Responsive Demand," February 2002. 


\section{1 major programs}

- Real-Time Dynamic Pricing

- Time of Use Pricing

- Demand Buyback

- Demand Bidding

- Demand or Direct Load Control

- Dispatchable Standby Generation

- Interruptible

- Black-Out Protection

- Event Driven Demand Reduction

- Pre-Determined Demand Reduction

- Curtailment (voluntary)

\section{Utilities}

- Tucson Electric

- Southern California Edison

- Sempra San Diego Gas \& Electric

- Pasadena Water and Power

- Sacramento Municipal Utility District

- Xcel Energy

- Idaho Power

- Bonneville Power Administration

- New Mexico PSC

- TNP Enterprises

- Portland GE

- Puget Sound Energy

- Salt River Project

- Los Angeles Dept. Water \& Power

- Vernon Municipal Light

- PacifiCorp

- Columbia River PUD (OR)

- Avista

- Pacific Gas \& Electric

- Platte River Power Authority

- Montana Power

- Silicon Valley Electric

- Eugene Water \& Electricity Board

- Springfield Utility Board

- Grant County PUD

- British Columbia Hydro \& Power Authority

- UtiliCorp Networks Canada Ltd.

- Saskatchewan Power

- Arizona Public Service 


\section{State Agency Programs}

- California Energy Commission

- California Independent System Operator

\section{CANADA - SASKATCHEWAN}

Saskatchewan has no formal demand response programs, however, customers may elect to choose time of day metering, using approved meters.

\section{CANADA - ALBERTA}

Alberta has no formal demand response programs. However, the entity that effects real time pricing, time of use pricing, and voluntary curtailment is the Power Pool of Alberta. The Power Pool operates the real time spot market in Alberta. Furthermore, the retailer EPCOR will design a demand response custom tariff for businesses that request one.

\section{Questions to be answered for each program:}

I. How does the program work?

II. What is the customer response?

III. What is the current rate charged by the utility and what form of compensation does the customer receive?

IV. Are special meters required?

\section{Matrix Key:}

1. Real Time Pricing

2. Time of Use Pricing

3. Demand Buyback

4. $\quad$ Demand Bidding

5. Direct Load Control

6. Dispatchable Standby Generation

7. Interruptible

8. Black Out Protection

9. Event Driven Demand Reduction

10. Predetermined Demand Reduction

11. Voluntary Curtailment 
Matrix 1. Arizona through Idaho

\begin{tabular}{|c|c|c|c|c|c|c|c|c|c|c|c|c|}
\hline & Power agencies & $\begin{array}{l}1 \\
\text { RTP }\end{array}$ & $\begin{array}{l}2 \\
\text { TOU }\end{array}$ & $\begin{array}{l}3 \\
\text { DByBk }\end{array}$ & DBid & $D L C$ & $\begin{array}{l}6 \\
D S G\end{array}$ & $I N T$ & $B O P$ & $E D D R$ & $\begin{array}{l}10 \\
1 \quad 0 \\
P D D R\end{array}$ & $\begin{array}{l}111 \\
V C\end{array}$ \\
\hline Alberta & Power Pool & $\underline{\mathrm{x}}$ & $\underline{\mathrm{x}}$ & & & & & & & & & $\underline{\mathrm{x}}$ \\
\hline & & & & & & & & & & & & \\
\hline \multirow[t]{3}{*}{ Arizona } & Tucson Electric & & $\underline{\mathrm{x}}$ & & & & & $\underline{\mathrm{x}}$ & & & & \\
\hline & Salt River Project & & $\underline{\mathrm{x}}$ & & & & & $\underline{\mathrm{x}}$ & & & & \\
\hline & Arizona Public Service & & $\underline{\mathrm{x}}$ & & & & & & & & & \\
\hline & & & & & & & & & & & & \\
\hline \multirow[t]{2}{*}{$\begin{array}{l}\text { British } \\
\text { Columbia }\end{array}$} & BC Hydro & $\underline{\mathrm{x}}$ & $\underline{\mathrm{x}}$ & $\underline{\mathrm{x}}$ & & & & $\underline{x}$ & & & $\underline{\mathrm{x}}$ & \\
\hline & UtiliCorp & & $\underline{\mathrm{x}}$ & & & & & & & & & \\
\hline & & & & & & & & & & & & \\
\hline \multirow[t]{11}{*}{ California } & Pacific Gas \& Elec & & $\underline{\mathrm{x}}$ & & $\underline{\mathrm{x}}$ & & & $\underline{\mathrm{x}}$ & $\underline{\mathrm{x}}$ & & & $\underline{\mathrm{x}}$ \\
\hline & Sempra SDG\&E & & $\underline{\mathrm{x}}$ & & $\underline{\mathrm{x}}$ & & & $\underline{\mathrm{x}}$ & $\underline{\mathrm{x}}$ & & & $\underline{\mathrm{x}}$ \\
\hline & Southern Cal Edison & $\underline{\mathrm{x}}$ & $\underline{\mathrm{x}}$ & & $\underline{\mathrm{x}}$ & & & $\underline{\mathrm{x}}$ & $\underline{\mathrm{x}}$ & $\underline{\mathrm{x}}$ & & \\
\hline & California ISO & & & & & & & $\underline{\mathrm{x}}$ & $\underline{\mathrm{x}}$ & & & $\underline{\mathrm{x}}$ \\
\hline & LADWP & & $\underline{\mathrm{x}}$ & & & & & & & & & \\
\hline & Pasadena W\&P & & & & & & & & & & & $\underline{\mathrm{x}}$ \\
\hline & Sacramento MUD & & $\underline{\mathrm{x}}$ & $\underline{\mathrm{x}}$ & & $\underline{\mathrm{x}}$ & & & & & & $\underline{\mathrm{x}}$ \\
\hline & Vernon Munic Light & & $\underline{\mathrm{x}}$ & & & & & & & & & \\
\hline & PacifiCorp & & $\underline{\mathrm{x}}$ & & & & & & & & & \\
\hline & Silicon Valley Elec. & & & & & & & & $\underline{x}$ & & & \\
\hline & $\begin{array}{l}\text { California Energy } \\
\text { Commission }\end{array}$ & $\underline{\mathrm{x}}$ & & & & & & & & & & $\underline{\mathrm{x}}$ \\
\hline & & & & & & & & & & & & \\
\hline & & & & & & & & & & & & \\
\hline \multirow[t]{2}{*}{ Colorado } & Xcel Energy & $\underline{\mathrm{x}}$ & $\underline{\mathrm{x}}$ & & & & & $\underline{\mathrm{x}}$ & & & & $\underline{\mathrm{x}}$ \\
\hline & $\begin{array}{l}\text { Platte River Power } \\
\text { Authority }\end{array}$ & & & & & & & & & & $\underline{\mathrm{x}}$ & \\
\hline & & & & & & & & & & & & \\
\hline & & & & & & & & & & & & \\
\hline \multirow[t]{4}{*}{ Idaho } & Idaho Power & & $\underline{\mathrm{x}}$ & $\underline{\mathrm{x}}$ & & & & & & & $\underline{\mathrm{x}}$ & \\
\hline & PacifiCorp & & $\underline{\mathrm{x}}$ & $\underline{\mathrm{x}}$ & & & & $\underline{\mathrm{x}}$ & & & & $\underline{\mathrm{x}}$ \\
\hline & $\begin{array}{l}\text { Bonneville Power } \\
\text { Administration }\end{array}$ & & & $\underline{\mathrm{x}}$ & & & & & & & & \\
\hline & Avista & & & $\underline{\mathrm{x}}$ & & & & & & & & \\
\hline
\end{tabular}


Matrix 2. Montana through Wyoming

\begin{tabular}{|c|c|c|c|c|c|c|c|c|c|c|c|c|}
\hline & Power agencies & $\begin{array}{l}1 \\
\text { RTP }\end{array}$ & $\begin{array}{l}2 \\
\text { TOU }\end{array}$ & $\begin{array}{l}3 \\
D B y B k\end{array}$ & $\begin{array}{l}4 \\
\text { DBid }\end{array}$ & $\begin{array}{l}5 \\
D L C\end{array}$ & $\begin{array}{l}6 \\
D S S\end{array}$ & $I N T$ & $\begin{array}{l}8 \\
B O P\end{array}$ & $\begin{array}{l}9 \\
E D D R\end{array}$ & $\begin{array}{l}110 \\
P D R\end{array}$ & $\begin{array}{l}111 \\
V C\end{array}$ \\
\hline \multirow[t]{2}{*}{ Montana } & $\begin{array}{l}\text { Bonneville Power } \\
\text { Administration }\end{array}$ & & & $\underline{\mathrm{x}}$ & & & & & & & & \\
\hline & Montana Power & & $\underline{\mathrm{x}}$ & & & & & & & & & \\
\hline & & & & & & & & & & & & \\
\hline \multirow{2}{*}{ Nevada } & Nevada Power & & $\underline{\mathrm{x}}$ & & & & & $\underline{\mathrm{x}}$ & & & & $\underline{\mathrm{x}}$ \\
\hline & Sierra Pacific & & $\underline{\mathrm{x}}$ & & & & & $\underline{\mathrm{x}}$ & & & & $\underline{\mathrm{x}}$ \\
\hline & & & & & & & & & & & & \\
\hline \multirow[t]{2}{*}{ New Mexico } & New Mexico PSC & & $\underline{\mathrm{x}}$ & & & & & & & & & \\
\hline & TNP Enterprises & & $\underline{\mathrm{x}}$ & & & & & $\underline{\mathrm{x}}$ & & & & \\
\hline & & & & & & & & & & & & \\
\hline & & & & & & & & & & & & \\
\hline \multirow[t]{7}{*}{ Oregon } & Portland GE & $\underline{\mathrm{x}}$ & $\underline{\mathrm{x}}$ & $\underline{\mathrm{x}}$ & & & $\underline{\mathrm{x}}$ & & & & & \\
\hline & PacifiCorp & $\underline{\mathrm{x}}$ & $\underline{\mathrm{x}}$ & $\underline{\mathrm{x}}$ & & & & & $\underline{\mathrm{x}}$ & & & $\underline{\mathrm{x}}$ \\
\hline & $\begin{array}{l}\text { Bonneville Power } \\
\text { Administration }\end{array}$ & & & $\underline{\mathrm{x}}$ & & & & & & & & \\
\hline & $\begin{array}{l}\text { Columbia River } \\
\text { PUD }\end{array}$ & & & & & & & & & & & $\underline{\mathrm{x}}$ \\
\hline & Idaho Power & & & $\underline{\mathrm{x}}$ & & & & & & & & \\
\hline & $\begin{array}{l}\text { Eugene Water \& } \\
\text { Electricity Board }\end{array}$ & & & $\underline{\mathrm{x}}$ & & & & & & & & \\
\hline & $\begin{array}{l}\text { Springfield Utility } \\
\text { Board }\end{array}$ & & & $\underline{\mathrm{x}}$ & & & & & & & & \\
\hline & & & & & & & & & & & & \\
\hline $\begin{array}{l}\text { Saskat- } \\
\text { chewan }\end{array}$ & SaskPower & & $\underline{\mathrm{x}}$ & & & & & & & & & \\
\hline & & & & & & & & & & & & \\
\hline \multirow[t]{3}{*}{ Utah } & PacifiCorp & & $\underline{\mathrm{x}}$ & $\underline{\mathrm{x}}$ & & & & $\underline{\mathrm{x}}$ & & & & $\underline{\mathrm{x}}$ \\
\hline & & & & & & & & & & & & \\
\hline & & & & & & & & & & & & \\
\hline \multirow[t]{5}{*}{ Washington } & Puget Sound Energy & & $\underline{\mathrm{x}}$ & $\underline{\mathrm{x}}$ & & & & & & & & \\
\hline & PacifiCorp & & & $\underline{\mathrm{x}}$ & & & & & & & & $\underline{\mathrm{x}}$ \\
\hline & $\begin{array}{l}\text { Bonneville Power } \\
\text { Administration }\end{array}$ & & & $\underline{\mathrm{x}}$ & & & & & & & & \\
\hline & Avista & & & $\underline{\mathrm{x}}$ & & & & & & & & \\
\hline & Grant County PUD & & & $\underline{\mathrm{x}}$ & & & & & & & & \\
\hline & & & & & & & & & & & & \\
\hline Wyoming & PacifiCorp & & & $\underline{\mathrm{x}}$ & & & & & & & & \\
\hline
\end{tabular}




\section{Real-Time Pricing}

In this program, prices vary on an hourly and/or day-ahead basis. Load changes in response to changes in prices or forecasts of day ahead prices are optional on the part of the customer.

\section{Southern California Edison (commercial/industrial)}

\section{General Service Large}

Commercial/Industrial Schedule RTP-2 (information taken from rate schedule)

I. In this program, three electric service demand levels are used: up to $2 \mathrm{kV} ; 2 \mathrm{kV}-$ $50 \mathrm{kV}$; above $50 \mathrm{kV}$. Rates are calculated based on the hour of the day, type of day (weekday or weekend) and the temperature via the national weather service during the summer or winter season.

[Extremely hot summer weekday (+95 degrees); very hot (91-94 degrees); hot (85-90 degrees); moderate (81-84 degrees); mild (<80 degrees)]; [High cost winter weekday (+91 degrees); low cost ( $<90$ degrees)];

[High cost summer/winter weekend ( +78 degrees) and low cost summer/winter weekend $(<77$ degrees) .

II. Number of participants is not available.

III.

\begin{tabular}{|l|l|l|l|}
\hline Charges & $\begin{array}{l}\text { Less than } \\
\mathbf{2 k V}\end{array}$ & $\mathbf{2 k V - 5 0 k V}$ & $\begin{array}{l}\text { Greater than } \\
\mathbf{5 0 k V}\end{array}$ \\
\hline $\begin{array}{l}\text { Customer charge } \\
\text { \$/meter/month }\end{array}$ & $\$ 298.65$ & $\$ 299.00$ & $\$ 349.45$ \\
\hline $\begin{array}{l}\text { Facilities Demand charge } \\
\text { /meter/month \$/kW }\end{array}$ & $\$ 6.40$ & $\$ 6.60$ & 65 cents \\
\hline $\begin{array}{l}\text { Procurement charge } \\
\text { (\$/kWh) }\end{array}$ & 11.834 cents & 11.180 cents & 9.310 cents \\
\hline $\begin{array}{l}\text { *Voltage discount } \\
\text { (hourly) }\end{array}$ & -- & $\$ 100.00$ & $\$ 100.00$ \\
\hline $\begin{array}{l}\text { Energy charge (\$/kWh) } \\
\text { **Power factor } \\
\text { adjustment (\$/kVA) }\end{array}$ & $\begin{array}{l}\text { Ranges from 0.05 } \\
\text { cents to \$3.01091 }\end{array}$ & $\begin{array}{l}\text { Ranges from } 0.05 \\
\text { cents to \$3.01091 }\end{array}$ & $\begin{array}{l}\text { Ranges from } 0.05 \\
\text { cents to \$3.01091 }\end{array}$ \\
\hline
\end{tabular}

*Voltage Discount - the discount applied to energy charges is calculated by taking the base rate energy charge multiplied by the percentage for service delivered and metered at a variety of voltages (e.g. $2 \mathrm{kV}$ through $50 \mathrm{kV}$ and greater than $50 \mathrm{kV}$.)

**Power Factor Adjustment - a clause in a rate schedule providing for an adjustment in the billing in case the power factor varies from a specified figure or range (e.g. 85\%). Power factor $=$ ratio of the real power $(\mathrm{KW})$ to the total apparent power (KVA).

The benefit is for customers to shift energy use to take advantage of lower price hours.

IV. A meter is required. The utility installs and pays for the meter, but the customer pays a monthly use charge. 


\section{$\underline{\text { Southern California Edison Real Time Pricing variations }}$}

\section{General Service (Schedule RTP-3-GS)}

This service is for customers with a monthly maximum demand of greater than $20 \mathrm{~kW}$, but not exceeding $500 \mathrm{~kW}$. Service is subject to meter availability. This schedule is suspended until such time as the California Energy Commission determines a method for calculating hourly prices based on different standards rather than hourly procured energy prices. Rates include a customer charge, demand charge, and energy charge. Each hour's energy charge is computed by multiplying the hour's kilowatt-hour usage by the hourly rate for that hour, and is applied on a cents-per-kilowatt-hour basis.

\section{General Service Large (Schedule RTP-3)}

For customers with a monthly maximum demand of: up to $2 \mathrm{kV} ; 2 \mathrm{kV}$ through $50 \mathrm{kV}$; and above $50 \mathrm{kV}$. Service is subject to meter availability. This schedule is suspended until such time as the CEC determines a method for calculating hourly prices based on different standards other than hourly power exchange prices. Rates include a customer charge, demand charge, and hourly energy charge. Each hour's energy charge shall be applied on a cents-per-kilowatt hour basis and is subject to change on an hourly basis. This hourly rate will equal the utility's hourly cost of procuring energy from the power exchange, plus the hourly transmission and distribution rates all multiplied by a factor of 1.721 , plus the public utility commission reimbursement fee and the California Alternate Rates for Energy Surcharge.

\section{General Service Large Interruptible (Schedule RTP-2-I)}

This service is optional for customers eligible under Schedule RTP-2 and is limited to customers who agree to participate in the Real Time Pricing program. This service is subject to meter availability. As of November 26, 1996, this schedule is closed except that existing customers adding new load can qualify with a minimum service level needed for their operation no less than their maximum demand in the proceeding 12 months. Customers newly taking service from Southern California Edison can take service under this schedule for electrical loads not previously served by the utility. Service under this schedule will expire December 31, 2002.

\section{Xcel Energy (commercial/industrial)}

\section{Primary Delivery Level}

Commercial/Industrial Schedule PRTP (information taken from rate schedule)

I. This service applies to customers who can demonstrate a maximum demand of not less than $500 \mathrm{~kW}$ for any month of the previous calendar year and whose electric power service is supplied at primary distribution voltage. The effective date of the program is May 1, 2000.

II. 3 participants ( 1 interruptible)

III. Energy prices are determined by a customer's increasing or decreasing energy consumption, as measured from the customer's baseline load during that hour. Daily pricing periods begin in the 24-hour period commencing at midnight.

\begin{tabular}{|l|l|l|l|l|l|l|}
\hline Rate Monthly & $\begin{array}{l}\text { Program } \\
\text { charge } \\
\text { /month }\end{array}$ & $\begin{array}{l}\text { Service } \\
\mathbf{\&} \\
\text { Facility } \\
\text { charge }\end{array}$ & $\begin{array}{l}\text { Baseline } \\
\text { production } \\
\text { charge } \\
\text { All } \mathbf{k W}\end{array}$ & $\begin{array}{l}\text { Access } \\
\text { charge } \\
\text { All } \mathbf{k W}\end{array}$ & $\begin{array}{l}\text { Baseline } \\
\text { energy } \\
\text { charge } \\
\text { All kWh }\end{array}$ & $\begin{array}{l}\text { RealTimePricing } \\
\text { energy charge }\end{array}$ \\
\hline & $\$ 200.00$ & $\$ 125.00$ & $\$ 8.97$ & $\$ 3.83$ & 1.612 cents & variable \\
\hline
\end{tabular}


The benefit for customers is shifting their energy use to periods when they can get a monetary credit on their bill.

IV. A meter is required and is paid for and installed by the utility. 


\section{$\underline{\text { Xcel Commercial/Industrial variations }}$}

\section{Commercial/Industrial - Primary Delivery Level \\ Primary Time of Day Real Time Pricing \\ Primary Interruptible Real Time Pricing}

Commercial/Industrial - Secondary Delivery Level

Applicable to customers whose electric power service is supplied at secondary distribution voltage.

Secondary Time of Day Real Time Pricing

Secondary Interruptible Real Time Pricing

Commercial/Industrial - Transmission Delivery Level

Applicable to customers whose electric power service is supplied at transmission distribution voltage.

Variations

Transmission Time of Day Real Time Pricing

Transmission Interruptible Real Time Pricing

\section{Portland General Electric (commercial - Oregon)}

Schedule 83 (information provided by Jack Breen, OR PUC)

This schedule is also offered under the Time of Use Pricing section. The difference is that in the real-time program, daily pricing is based on the DOW JONES MID-COLUMBIA DAILY on-peak and off-peak ELECTRICITY FIRM PRICE INDEX plus .243 cents per $\mathrm{kWh}$, plus losses.

\section{PacifiCorp (commercial - Oregon)}

\section{Standard Offer - Supply Service}

Commercial Schedule 220 (information provided by Jack Breen, OR PUC)

Daily pricing under this schedule is based on the DOW JONES MID-COLUMBIA DAILY on-peak and off-peak ELECTRICITY FIRM PRICE INDEX plus .243 cents per kWh, plus losses.

\section{California Energy Commission (commercial)}

Cash for Kilowatts Program (information provided by Mike Messenger, CEC)

I. Customers and/or aggregators are provided cash incentives of up to $\$ 150 / \mathrm{kW}$ of capacity reduction pledge to install interval meters and the communications necessary to respond to requests for reductions from the California Independent Systems Operator or UDC's. Customer response is voluntary and depends on whether the customers have signed up for any pay for capacity or energy demand response programs. The capacity reduction estimate pledged in the contract or grant is verified during a pilot test from $2 \mathrm{pm}$ to $6 \mathrm{pm}$ to measure the actual load reduction achieved before the critical summer period begins. 
II. Over 300 customers installed systems and provided roughly $200 \mathrm{MW}$ of demand reduction capability for the summer of 2001. However, curtailments were only called once during the summer of 2001 on July $3^{\text {rd }}$ due to conservation response that limited the number of stage 2 emergencies to 1 event all summer.

III. Utility energy and capacity prices for curtailments are proposed, debated, and approved by the California Public Utilities Commission. The California Department of Water Resources also has a small bidding program that allows it to respond to price bids to curtail specific amounts of load during high price periods.

IV. A meter capable of recording electricity use every 15 minutes is required.

\section{California Energy Commission (infrastructure)}

Real-Time Meter Installation Program (information provided by Mike Messenger, CEC)

I. This program funded the installation of 23,375 interval meters and appropriate communications links for customer facilities having a peak demand of $200 \mathrm{~kW}$ or higher. These meters give customers the capability of monitoring their energy use by time period over an Internet-based access system provided as part of the basic package, or through commercially available software, which customers can purchase, if real-time (e.g. hourly) data access is desired. The goal of the program is to establish the metering infrastructure to enable customers to participate in load reduction/curtailment programs during the summer of 2001, and to prepare the largest commercial/industrial customer classes for real-time electricity pricing schedules soon to be authorized by the California Public Utilities Commission.

II. Total project cost was $\$ 34$ million and could lead to peak reductions ranging from 400 to $700 \mathrm{MW}$, depending on what rates are available to customers and the actual price signals sent to the customers in the year 2002 and beyond.

\section{British Columbia Hydro \& Power Authority (CANADA) (commercial/industrial)}

\section{Real-Time Pricing Transmission Service}

Commercial/Industrial Schedule 1848 (information provided by Denise Mullen-Dalmer)

I. This service provides access to market-based prices for incremental and decremental energy for transmission voltage customers. The RTP rate applies to energy above or below the Customer Baseline Load (CBL). THE CBL for energy and demand in each billing period is used to calculate the customer's fixed charge and the energy use in the HLH and LLH is used to calculate the customer's RTP energy charge.

II. Customer response has varied depending on the market price of electricity. Currently, the Commission is not aware of any customers currently using the RTP rate.

III. Pricing is based on either:

The Dow Jones Mid-C Firm Index Price for LLH and LLH

The Dow Jones Mid-C Non-Firm Index Price for LLH and HLH

The mid-point of the Dow Jones Mid-C Non-Firm One-Day Preschedule Price Range for HLH and LLH. 
The choice of pricing option is the customer's but, once chosen, cannot be changed for a three-month period. In addition, the customer may arrange to buy block power at a negotiated price. Firm transmission capacity above the customer's Maximum $\mathrm{kV}$.A demand may be provided, if available, at $\$ 4.411 / \mathrm{kV} . \mathrm{A} / \mathrm{month}$.

IV. Real-time metering and associated telecommunications equipment is required.

\section{CANADA - ALBERTA}

Alberta has no formal demand response programs. However, the entity that effects real time pricing, time of use pricing, and voluntary curtailment is the Power Pool of Alberta. The Power Pool operates the real time spot market in Alberta. Furthermore, the retailer EPCOR will design a demand response custom tariff for businesses that request one. 
Time of Use

Time-of-use rates are designed to more closely reflect the utility cost structure where rates are higher during peak periods and lower during off-peak periods. Rates are not based on real-time prices in the marketplace.

\section{Los Angeles Department of Water and Power (commercia/industrial)}

Commercial/Industrial Schedules A-1 \& A-2 (information taken from rate schedule)

I. In these voluntary programs, the utility offers electricity to customers at two different rates. Electricity use is measured in three pricing periods (high, low, and base).

These apply to: general service below $30 \mathrm{~kW}$ demand for small businesses and 30 $\mathrm{kW}$ demand or greater, but less than $500 \mathrm{~kW}$ of demand, for medium size businesses. High price hours are (1-5 pm, M-F). Low price hours are (10 am -1 pm and 5-8 pm, M-F). Baseline hours are (8 pm - 9:59 am) weekdays, and all day Saturday and Sunday.

II. There are 3,438 small size business participants on this schedule and 4,231 medium size business participants.

III.

\begin{tabular}{|l|l|l|r|l|}
\hline \multicolumn{2}{|c|}{ Rate A-1b } & \multicolumn{2}{c|}{ Rate A-2b } \\
\hline & June-Oct & Nov-May & June-Oct & Nov-May \\
\hline Service charge & $\$ 7.00 /$ month & $\$ 7.00 /$ month & $\$ 25.00 /$ month & $\$ 25.00 /$ month \\
\hline $\begin{array}{l}\text { Facilities } \\
\text { charge/kW }\end{array}$ & $\$ 2.25$ & $\$ 2.25$ & $\$ 2.25$ & $\$ 2.25$ \\
\hline Demand charge/kW & & & & \\
\hline Hi peak & -- & -- & $\$ 8.63$ & $\$ 7.90$ \\
\hline Low peak & -- & -- & $\$ 4.21$ & $\$ 3.85$ \\
\hline Base period & -- & -- & $\$ 1.40$ & $\$ 1.40$ \\
\hline Energy charge/kWh & & & & \\
\hline Hi peak & 15.194 cents & 15.194 cents & 2.949 cents & 2.949 cents \\
\hline Low peak & 8.487 cents & 8.487 cents & 2.907 cents & 2.907 cents \\
\hline Base period & 3.393 cents & 3.393 cents & 1.658 cents & 1.658 cents \\
\hline
\end{tabular}

The benefit is shifting hours of operation from peak hours to off peak demand times.

IV. A meter is required and the utility pays for and installs it.

\section{Los Angeles Department of Water and Power (residential)}

Residential Schedule B (information taken from rate schedule)

I. In this voluntary program the utility offers electricity to customers at three different rates. Electricity use is measured in three pricing periods. High price hours (1-5 pm, $\mathrm{M}-\mathrm{F})$; low price, low use hours (10 am - $1 \mathrm{pm}$ and 5-8 pm, M-F); base hours (8 pm 9:59 am) weekdays, and all day Saturday and Sunday.

II. Participants: 1,818

III.

\begin{tabular}{|l|l|}
\hline Service charge/month & $\$ 6.00$ \\
\hline Hi-peak $/ \mathbf{k W h}$ & 14.377 cents \\
\hline Low-peak $/ \mathbf{k W h}$ & 8.793 cents \\
\hline Base $/ \mathbf{k W h}$ & 3.780 cents \\
\hline
\end{tabular}

Benefit is shifting use to base hours, which lowers monthly bill.

IV. A meter is required. The utility pays for and installs the meter at no cost, but the customer pays a monthly use fee. 


\section{Vernon California Municipal Light (commercial/industrial)}

Commercial/Industrial Schedule TOU-G (information taken from rate schedule)

I. This service is elective for customers with a monthly maximum demand that exceeds $200 \mathrm{~kW}$ for three months during the preceding twelve months, but is less than $500 \mathrm{~kW}$ for any nine months during the preceding twelve months. Time periods affected, except holidays, are as follows: On peak summer weekdays (1-7 pm); On-peak winter weekdays (5-10 pm); Mid-peak summer weekdays (9 am-1 pm and 7 pm-11 pm); Mid-Peak winter weekdays (8 am $-5 \mathrm{pm})$.

II. 200 participants

III.

\begin{tabular}{|l|l|l|l|l|l|l|}
\hline $\begin{array}{l}\text { Customer charge } \\
\text { /meter/month }\end{array}$ & \multicolumn{5}{|c|}{$\$ 159.50$} \\
\hline & On-Peak & Mid-Peak & Off-Peak & On-Peak & Mid-Peak & Off-Peak \\
\hline May-Jun-Oct & $\$ 8.999$ & $\$ 1.650$ & -- & 5.33 cents & $\begin{array}{l}4.995 \\
\text { cents }\end{array}$ & $\begin{array}{l}4.493 \\
\text { cents }\end{array}$ \\
\hline Jul-Aug-Sept & $\$ 10.635$ & $\$ 1.650$ & -- & $\begin{array}{l}6.645 \\
\text { cents }\end{array}$ & $\begin{array}{l}6.310 \\
\text { cents }\end{array}$ & $\begin{array}{l}5.176 \\
\text { cents }\end{array}$ \\
\hline Nov-Apr & $\$ 8.999$ & $\$ 1.650$ & -- & 5.33 cents & $\begin{array}{l}4.995 \\
\text { cents }\end{array}$ & $\begin{array}{l}4.493 \\
\text { cents }\end{array}$ \\
\hline
\end{tabular}

The benefit is shifting hours of operation from high-peak hours.

IV. A meter is required. The utility pays for and installs the meter at no charge, but the customer pays a monthly use fee.

\section{Salt River Project (commercial/industrial)}

\section{Commercial/Industrial Schedule E-32 (information taken from rate schedule)}

I. This program is for customers with a demand ranging from less than $5 \mathrm{~kW}$ to $1000 \mathrm{~kW}$ and who are able to take advantage of the lower prices in the shoulder-peak and offpeak periods. Three time periods affect price: on-peak, shoulder-peak, and off-peak hours -- depending on the season. There are two seasons: Summer season (May $1-$ October 31) and Winter season (November 1 - April 30.) On-peak summer hours are $(2 \mathrm{pm}-7 \mathrm{pm}) \mathrm{M}-\mathrm{F}$. Shoulder-peak hours are (11 am $-2 \mathrm{pm}$ and $7 \mathrm{pm}-11 \mathrm{pm}) \mathrm{M}-\mathrm{F}$. Off-peak summer hours are all other hours plus weekends and holidays. On-peak winter hours are (5am - 9 am M-F). Shoulder-peak winter hours are $(5 \mathrm{pm}-9 \mathrm{pm}$ M-F). Off-peak winter hours are all other hours plus holidays.

II. 2,000 participants

III.

\begin{tabular}{|l|l|l|}
\hline $\begin{array}{l}\text { Customer charge } \\
\text { /meter/month }\end{array}$ & \multicolumn{2}{|c|}{$\$ 33.88$} \\
\hline & \multicolumn{1}{|c|}{ summer } & \multicolumn{1}{c|}{ winter } \\
\hline On-peak $/ \mathbf{k W}$ & $\$ 4.73$ & $\$ 3.38$ \\
\hline Shoulder-peak $/ \mathbf{k W}$ & $\$ 0.46$ & $\$ 0.26$ \\
\hline Off-peak $/ \mathbf{k W}$ & -- & -- \\
\hline On-peak /kWh & 9.17 cents & 8.70 cents \\
\hline Shoulder-peak /kWh & 6.70 cents & 6.35 cents \\
\hline Off-peak $/ \mathbf{k W h}$ & 3.25 cents & 3.25 cents \\
\hline
\end{tabular}

The benefit is to those customers who can take advantage of the lower prices in the shoulder-peak and off-peak periods. 
IV. A meter is required. The utility pays for and installs them at no cost, but the customer pays a monthly use fee. 


\section{Salt River Project (residential)}

Residential Schedule E-26 (information taken from rate schedule)

I. This is a program for customers who use at least $1,000 \mathrm{kWh}$ of electricity during the summer months. Two time periods affect price: on-peak and off-peak hours -depending on the season. There are two seasons: Summer (May 1-Oct 31). Winter (Nov 1-Apr 30). On-peak summer hours are (1pm $-8 \mathrm{pm})$ weekdays. Off-peak summer hours are all other hours plus holidays. On-peak winter hours are $(5 \mathrm{am}-9$ am) weekdays and ( $5 \mathrm{pm}-9 \mathrm{pm})$ weekdays. Off-peak hours are all other hours plus holidays.

II. $20 \%$ of residential customers participate in this program (no other information)

III.

\begin{tabular}{|l|l|l|}
\hline $\begin{array}{l}\text { Service charge } \\
\text { /meter/month }\end{array}$ & \multicolumn{2}{|c|}{$\$ 10.96$} \\
\hline & \multicolumn{1}{|c|}{ summer } & \multicolumn{1}{|c|}{ winter } \\
\hline On-peak $/ \mathbf{k W h}$ & 16.50 cents & 6.42 cents \\
\hline Off-peak $/ \mathbf{k W h}$ & 3.69 cents & 5.63 cents (first $400 \mathrm{kWh})$ \\
\hline Off-peak $/ \mathbf{k W h}$ & & 3.01 cents (all additional $\mathrm{kWh}$ ) \\
\hline
\end{tabular}

The benefit is for customers who can shift usage to off-peak periods for lower prices.

IV. A meter is required. The utility pays for and installs meters, but the customer is charged a monthly use fee.

\section{Southern California Edison (commercial/industrial)}

\section{Scheduled Load Reduction Program}

Commercial/Industrial Schedule SLRP (information taken from rate schedule)

I. This is a service for customers with a demand of $100 \mathrm{~kW}$ and above who voluntarily reduce 15 percent of their maximum demand over the previous 12 months, which shall not be less than $100 \mathrm{~kW}$, during pre-scheduled weekdays and time periods throughout the summer season (June 1 - Sept 30).

There are three four-hour time periods targeted:

Option A -- 8 am - 12 pm M-F

Option B -- $12 \mathrm{pm}-4 \mathrm{pm} \mathrm{M}-\mathrm{F}$

Option C -- 4 pm - 8 pm M-F

Customers may participate up to three days per week, but may not choose the same time period more than twice a week. This program is also for customers who can shift their operations to the off-peak period while curtailing load during one or all of the four-hour time periods of the program between the hours of $8 \mathrm{am}-8 \mathrm{pm}$.

II. 8 participants. Payment is very small.

III. The pricing rate is determined by a customer-specific energy baseline. This methodology is derived by tracking each hour's $\mathrm{kWh}$ average for 10 days of the customer's average rolling energy usage, by the utility, which corresponds to the chosen time period of a reduction event. There is no penalty for not reducing power, but a customer must reduce power in every hour of an event in order to receive a monetary credit on their bill.

The benefit is that customers will receive a credit on their bill (within 30-90 days after they reduce power) in the amount of 10 cents per $/ \mathrm{kWh}$. 
IV. A meter is required. The utility pays for and installs the meter at no cost. However, to get the meter, customers must agree to participate for one year and comply with at least 5 program load reduction events. 


\section{Southern California Edison (residential)}

Residential Schedule D-1 (information taken from rate schedule)

I. This program is for customers who use less than $600 \mathrm{kWh} / \mathrm{month}$, mostly during offpeak hours. On-peak hours occur 10 am -6 pm summer and winter weekdays. Offpeak hours are all other hours, all year, everyday.

II. $\quad 500$ participants

III.

\begin{tabular}{|c|c|c|}
\hline & Summer & Winter \\
\hline Basic single family/meter/day & 3.3 cents & 3.3 cents \\
\hline Basic multi family/meter/day & 2.5 cents & 2.5 cents \\
\hline TOU charge/meter/day & 8 cents & 8 cents \\
\hline \multicolumn{3}{|l|}{ Energy charge/meter/day/kWh } \\
\hline On-peak & 52.323 cents & 17.743 cents \\
\hline Off-peak & 0.14107 cents & 12.768 cents \\
\hline Baseline credit all kWh/meter/day & $(2.148)$ cents & (2.148) cents \\
\hline \multicolumn{3}{|l|}{ Minimum charge } \\
\hline \multicolumn{3}{|l|}{ Single family residence } \\
\hline \multicolumn{3}{|l|}{ Multi family residence } \\
\hline All on-peak kWh, per kWh & 40.301 cents & 5.721 cents \\
\hline All off-peak kWh, per kWh & 2.085 cents & 0.746 cents \\
\hline
\end{tabular}

The benefit to the customer is in using most of their electricity during off-peak hours to take advantage of the lower rates.

IV. A meter is required. The utility pays for and installs the meter at no cost, but the customer pays a monthly use fee.

\section{Southern California Edison (residential)}

Residential Schedule D-2 (information taken from rate schedule)

I. This rate is for customers who use more than $600 \mathrm{~kW} /$ month, mostly during off-peak hours. On-peak occurs at $10 \mathrm{am}-6 \mathrm{pm}$ summer weekdays and $10 \mathrm{am}-6 \mathrm{pm}$ winter weekdays. Off-peak occurs during all other hours, all year, everyday.

II. $\quad 3,800$ participants

III.

\begin{tabular}{|l|l|l|}
\hline & Summer & Winter \\
\hline $\begin{array}{l}\text { Customer charge } \\
\text { /meter/day }\end{array}$ & 0.26 cents & 0.26 cents \\
\hline $\begin{array}{l}\text { TOU charge } \\
\text { /meter/day }\end{array}$ & 0.08 cents & 0.08 cents \\
\hline $\begin{array}{l}\text { Energy charge/ } \\
\text { meter/day- all kWh }\end{array}$ & & \\
\hline \multicolumn{1}{|c|}{ On-peak } & 0.43 cents & 0.15 cents \\
\hline Off-peak & 0.12 cents & 0.11 cents \\
\hline
\end{tabular}

The benefit to the customer is in using most of their electricity during off-peak hours to take advantage of the lower rates.

IV. A meter is required. The utility pays for and installs the meter at no cost, but the customer pays for a monthly use fee. 


\section{Southern California Edison (agricultural)}

Agricultural/Pumping Schedule TOU-PA ( information taken from rate schedule)

I. This schedule offers two options. Rate A features a connected load charge and Rate

$\mathrm{B}$ features a demand charge. On-peak hours are from noon to $6 \mathrm{pm}$ on summer weekdays, except holidays. Mid-peak hours are from 8 am to noon and $6 \mathrm{pm}$ to 11 pm summer weekdays, except holidays. Mid-peak winter hours are 8 am to $9 \mathrm{pm}$ weekdays, except holidays. Off-peak is all other hours.

II. $\quad 5,300$ participants

III.

\begin{tabular}{|l|l|l|}
\hline & Summer & Winter \\
\hline & \multicolumn{2}{|c|}{ Rate A (connected load) } \\
\hline $\begin{array}{l}\text { Customer charge } \\
\text { /meter/month }\end{array}$ & $\$ 42.80$ & $\$ 42.80$ \\
\hline Service charge (2hp+) & $\$ 2.40$ & $\$ 2.40$ \\
\hline Energy charge/kWh & & \\
\hline On-peak & 20 cents & N/A \\
\hline Mid-Peak & 11 cents & 13 cents \\
\hline Off-peak & 6 cents & 6 cents \\
\hline
\end{tabular}

\begin{tabular}{|c|l|l|}
\hline & Summer & Winter \\
\hline & \multicolumn{2}{|c|}{ Rate B (demand metered) } \\
\hline Customer chg/m/mo & $\$ 42.80$ & $\$ 42.80$ \\
\hline Demand chg/kW all & $\$ 2.85$ & $\$ 2.85$ \\
\hline Time component & & \\
\hline On-Peak/kW all & $\$ 9.00$ & N/A \\
\hline Mid-Peak/kW all & 0 & 0 \\
\hline Off-peak/kW all & 0 & 0 \\
\hline Energy chg $\$ \mathbf{k W h}$ & & \\
\hline On-peak & 17 cents & N/A \\
\hline Mid-Peak & 9 cents & 11 cents \\
\hline Off-peak & 6 cents & 6 cents \\
\hline
\end{tabular}

The benefit to customers is shifting use to lower rate time periods.

IV. A meter is required. The utility pays for and installs the meter at no cost, but the customer pays a monthly use fee.

\section{$\underline{\text { Southern California Edison Agricultural variations }}$}

\section{Schedule TOU PA-3}

This schedule provides two optional 3 hour on-peak time-of-use periods: $1 \mathrm{pm}$ to $4 \mathrm{pm}$ and $2 \mathrm{pm}$ to $5 \mathrm{pm}$ on summer weekdays, except holidays.

\section{Schedule TOU PA-4}

This schedule provides three optional 4-hour on-peak periods during summer weekdays, except holidays: Noon to $4 \mathrm{pm}$ or $1 \mathrm{pm}$ to $5 \mathrm{pm}$ or $2 \mathrm{pm}$ to $6 \mathrm{pm}$.

\section{Schedule TOU PA-5}

This schedule is an option for customers that have at least 35 horsepower of connected load or $35 \mathrm{~kW}$ of measurable demand. This rate schedule has a minimum charge based on demand.

\section{Schedule TOU PA-SOP}

This schedule is similar to TOU-PA, but includes a super off-peak period from midnight to 6 am when energy charges are lowest. It has a four hour on-peak period, instead of the six hour on-peak period of TOU-PA, and a shorter summer season. Under this schedule you can 
choose to have the summer season start a month later or have it end one month earlier than the TOU-PA summer season.

\section{Schedule TOU PA-SOP-(I) Interruptible}

This schedule is for customers with a measured demand of $50 \mathrm{~kW}$ or better or with a connected load of 50 horsepower or greater. Service is subject to meter availability.

\section{Southern California Edison (commercial/industrial)}

\section{General Service Large}

Commercial/Industrial Schedule TOU-8 (information taken from rate schedule)

I. This schedule is mandatory for all customers whose monthly maximum demand is expected to exceed $500 \mathrm{~kW}$ or has exceeded $500 \mathrm{~kW}$ in any three months during the preceding 12 months. Customers currently using this schedule may elect service under any optional schedule. Service is distributed at three transmission voltage levels: below $2 \mathrm{kV} ; 2 \mathrm{kV}$ through $50 \mathrm{kV}$; and above $50 \mathrm{kV}$. Time periods are defined as follows: Summer weekday on-peak hours (noon $-6 \mathrm{pm}$ ). Summer weekday mid-peak hours ( 8 am-noon and $6 \mathrm{pm}-11 \mathrm{pm})$. Winter weekday mid-peak hours (8 am - 9 pm). Off-peak hours are all other hours.

II. $\quad 3,900$ total participants for this service and all its variations.

III.

\begin{tabular}{|c|c|c|c|c|c|c|}
\hline & \multicolumn{2}{|c|}{ Less than $2 \mathrm{kV}$} & \multicolumn{2}{|c|}{$2 \mathrm{kV}-50 \mathrm{kV}$} & \multicolumn{2}{|c|}{ Greater than $50 \mathrm{kV}$} \\
\hline & summer & winter & summer & winter & summer & winter \\
\hline $\begin{array}{l}\text { Customer } \\
\text { charge } \\
\text { /meter/month }\end{array}$ & $\$ 298.65$ & & $\$ 299.00$ & & $\$ 349.45$ & \\
\hline $\begin{array}{l}\text { Facilities } \\
\text { demand } \\
\text { charge } \\
\text { /meter/month }\end{array}$ & $\$ 6.40$ & $\$ 6.40$ & $\$ 6.60$ & $\$ 6.60$ & 65 cents & 65 cents \\
\hline $\begin{array}{l}\text { Time Demand } \\
\text { charge/kW }\end{array}$ & & & & & & \\
\hline On peak & $\$ 17.55$ & N/A & $\$ 17.95$ & N/A & $\$ 16.15$ & N/A \\
\hline Mid peak & $\$ 2.80$ & $\$ 2.80$ & $\$ 2.70$ & $\$ 2.70$ & $\$ 2.45$ & $\$ 2.45$ \\
\hline Off peak & -- & -- & -- & -- & -- & -- \\
\hline $\begin{array}{l}\text { Energy } \\
\text { demand } \\
\text { charge } \$ / \mathbf{k W h}\end{array}$ & & & & & & \\
\hline On peak & 20 cents & N/A & 19 cents & $\mathrm{N} / \mathrm{A}$ & 18 cents & $\mathrm{N} / \mathrm{A}$ \\
\hline Mid peak & 11 cents & 12 cents & 10 cents & 12 cents & 9 cents & 11 cents \\
\hline Off peak & 8 cents & 8 cents & 8 cents & 8 cents & 8 cents & 8 cents \\
\hline $\begin{array}{l}\text { Summer peak } \\
\text { rate limiter } \\
\$ / \mathbf{k W h}\end{array}$ & $\$ 1.20$ & NA & $\$ 1.19$ & NA & $\$ 1.03$ & NA \\
\hline $\begin{array}{l}\text { Summer } \\
\text { average rate } \\
\text { limiter } \$ / \mathbf{k W h}\end{array}$ & 37 cents & NA & 36 cents & NA & NA & NA \\
\hline
\end{tabular}

*Peak-period Rate Limiter - for customers at any voltage service level, summer bills will be reduced, if necessary, so that the average rate paid for all on-peak demand and energy charges during a summer peak period does not exceed the peak-period rate limiter shown on this schedule.

**Average Rate Limiter - for customers taking service in the secondary or primary voltage class, summer bills will be reduced, if necessary, so that the average rate paid for all demand and energy charges does not exceed the average rate limiter shown on this schedule.

The benefit for customers is to shift energy use to lower price hours.

IV. A meter is required. The utility installs and pays for the meter at no cost, but the 
customer pays a monthly use fee. 


\section{$\underline{\text { Southern California Edison Commercial TOU variations }}$}

\section{General Service Large - Super Off-Peak (TOU-8-SOP)}

This schedule is optional for customers and subject to meter availability. Service is supplied at one of three voltage levels: below $2 \mathrm{kV}, 2 \mathrm{kV}$ through $50 \mathrm{kV}$, and above $50 \mathrm{kV}$.

\section{General Service Large - Super Off-Peak (TOU-8-SOP-RTP Experimental)}

This schedule is optional for customers and subject to meter availability. Service is supplied at one of three voltage levels: below $2 \mathrm{kV}, 2 \mathrm{kV}$ through $50 \mathrm{kV}$, and above $50 \mathrm{kV}$. This schedule will expire with commencement of the Power Exchange operation.

General Service Large - TOU, RTP, On-Peak, Demand Charge (TOU-8-RTP)

This schedule is optional for all non-interruptible schedule TOU-8 customers. Service is supplied at one of three voltage levels: below $2 \mathrm{kV}, 2 \mathrm{kV}$ through $50 \mathrm{kV}$, and above $50 \mathrm{kV}$.

This schedule is closed to new customers.

\section{General Service Large - Back-Up Service (TOU-8-BU)}

This schedule is available when the maximum demand for the load to which back-up service is provided is expected to exceed $500 \mathrm{~kW}$. Back-up service is not to be used to serve the load that is curtailed/interrupted under a load curtailment program during a Stage III Emergency Rotating Outage. This service shall only be provided when SCE's service is not available at the main service. Service is supplied at three voltage levels: below $2 \mathrm{kV}, 2 \mathrm{kV}-50 \mathrm{kV}$, and above $50 \mathrm{kV}$. Service is subject to meter availability.

General Service Large Super Off-Peak - Interruptible (TOU-8-SOP-I)

This schedule is optional for customers and subject to meter availability. Service is supplied at one of three voltage levels: below $2 \mathrm{kV}, 2 \mathrm{kV}$ through $50 \mathrm{kV}$, and above $50 \mathrm{kV}$. This schedule is closed as of November 26, 1996 except to existing customers adding new load with a service level no less than their maximum demand in the preceding 12 months or customers not previously served by the company. Service under this schedule will expire December 31, 2002.

General Service Large - Interruptible (TOU-I-6)

This schedule is optional for customers. Service is supplied at one of three voltage levels: below $2 \mathrm{kV}, 2 \mathrm{kV}$ through $50 \mathrm{kV}$, and above $50 \mathrm{kV}$. This schedule is closed as of November 26, 1996 except to existing customers adding new load with a service level no less than their maximum demand in the preceding 12 months or customers not previously served by the company. Service under this schedule will expire December 31, 2002.

\section{Southern California Edison (commercial/industrial)}

General Service Demand Metered

Commercial/Industrial Schedule TOU-GS-2 (information taken from rate schedule)

I. This service is for customers whose monthly maximum demand does not exceed $500 \mathrm{~kW}$, but does not fall below $20 \mathrm{~kW}$ for three months in a row. Service is subject to meter availability. The customer must elect either Option A or Option B of the Time Related Component of the demand and the energy charge. Two seasons apply: summer and winter. Time periods are as follows: Summer on-peak hours are noon$6 \mathrm{pm}$ weekdays. Summer mid-peak hours are $8 \mathrm{am}-$ noon and $6 \mathrm{pm}$ through $11 \mathrm{pm}$ weekdays. Winter mid-peak hours are 8 am to 9 pm weekdays. All other hours are considered off-peak.

II. 1900 participants 
III.

\begin{tabular}{|l|l|l|l|l|}
\hline & Option A & Option B & winter \\
\cline { 2 - 5 } & summer & winter & summer & \\
\hline $\begin{array}{l}\text { Customer } \\
\text { charge/meter/month }\end{array}$ & $\$ 79.25$ & $\$ 79.25$ & $\$ 79.25$ & $\$ 79.25$ \\
\hline $\begin{array}{l}\text { Facility demand } \\
\text { charge } / \mathbf{k W}\end{array}$ & $\$ 5.40$ & $\$ 5.40$ & $\$ 5.40$ & $\$ 5.40$ \\
\hline $\begin{array}{l}\text { Time Component } \\
\text { /kW }\end{array}$ & & & & \\
\hline On-peak & $\$ 7.75$ & $\mathrm{~N} / \mathrm{A}$ & $\$ 16.40$ & $\mathrm{~N} / \mathrm{A}$ \\
\hline Mid-peak & $\$ 2.45$ & 0 & $\$ 2.45$ & 0 \\
\hline Off-peak & 0 & 0 & 0 & 0 \\
\hline Energy chg $\$ \mathbf{k W h}$ & & & & $\mathrm{N} / \mathrm{A}$ \\
\hline On-peak & 29 cents & $\mathrm{N} / \mathrm{A}$ & 21 cents & 12 cents \\
\hline Mid-peak & 11 cents & 12 cents & 11 cents & 9 cents \\
\hline Off-peak & 9 cents & 9 cents & 9 cents & . \\
\hline
\end{tabular}

The benefit is for customers who are able to shift energy use to lower price hours.

IV. A meter is required. The utility pays for and installs the meter at no cost, but the customer pays a monthly use fee.

\section{Southern California Edison variation}

\section{General Service Demand Metered}

Commercial/Industrial Schedule TOU-GS-2-SOP

This schedule is for customers whose monthly maximum demand does not exceed $500 \mathrm{~kW}$ but does not fall below $20 \mathrm{~kW}$. Service is subject to meter availability.

\section{Sempra San Diego Gas \& Electric (commercial/industrial)}

\section{General Service - Time Metered}

Commercial/Industrial Schedule AL-TOU (information taken from rate schedule)

I. This schedule applies to all metered, non-residential customers whose monthly maximum demand equals, exceeds, or is expected to equal or exceed $20 \mathrm{~kW}$. This schedule is optionally available to three-phase residential service, as well as metered, non-residential customers whose monthly maximum demand is less than $20 \mathrm{~kW}$. There are two seasons in this program: Summer (May 1 - Sept 30) and Winter (Oct 1 - April 30). On-peak, semi-peak, and off-peak time periods apply to this schedule. On-peak summer hours are 11 am to 6 pm weekdays. Winter on-peak hours are $5 \mathrm{pm}$ to $8 \mathrm{pm}$ weekdays. Summer semi-peak hours are weekdays 6 am to 11 am and $6 \mathrm{pm}$ to $10 \mathrm{pm}$. Winter semi-peak hours are 6 am to $5 \mathrm{pm}$ and $8 \mathrm{pm}$ to $10 \mathrm{pm}$ weekdays. Off-peak summer and winter hours are $10 \mathrm{pm}$ to 6 am weekdays, plus weekends and holidays.

II. Number of participants is not available. 
III.

\begin{tabular}{|c|c|c|c|c|c|}
\hline Charges & Secondary & Primary & $\begin{array}{l}\text { Secondary } \\
\text { substation }\end{array}$ & $\begin{array}{l}\text { Primary } \\
\text { substation }\end{array}$ & Transmission \\
\hline \multicolumn{6}{|l|}{$\begin{array}{l}\text { Basic service fees } \\
\text { (\$/month) }\end{array}$} \\
\hline $0-500 \mathrm{~kW}$ & 46.14 & 46.14 & $13,179.65$ & $13,179.65$ & 46.14 \\
\hline $\begin{array}{l}\text { greater than } \\
500 \mathrm{~kW}\end{array}$ & 184.55 & 184.55 & $13,179.65$ & $13,179.65$ & 184.55 \\
\hline $\begin{array}{l}\text { greater than } \\
12 \mathrm{MW}\end{array}$ & -- & -- & $20,752.11$ & $20,752.11$ & -- \\
\hline $\begin{array}{l}\text { Distance } \\
\text { adjustment fee }\end{array}$ & $\begin{array}{l}\text { OH-1.17 } \\
\text { UG-3.02 } \\
\end{array}$ & $\begin{array}{l}\text { OH-1.16 } \\
\text { UG-2.98 } \\
\end{array}$ & -- & -- & -- \\
\hline $\begin{array}{l}\text { Demand charges } \\
(\$ / k W) \\
\text { Non-Coincident }\end{array}$ & 6.06 & 5.92 & 93 cents & 54 cents & 53 cents \\
\hline \multicolumn{6}{|l|}{$\begin{array}{l}\text { Maximum } \\
\text { on-peak }\end{array}$} \\
\hline Summer & 9.99 & 9.63 & 6.62 & 5.84 & 5.80 \\
\hline Winter & 4.47 & 4.40 & 1.60 & 1.37 & 1.37 \\
\hline $\begin{array}{l}\text { *Power Factor } \\
\text { (\$/kvar) }\end{array}$ & 24 cents & 24 cents & 24 cents & 24 cents & -- \\
\hline \multicolumn{6}{|l|}{$\begin{array}{l}\text { Energy charges } \\
\text { (\$/kWh) }\end{array}$} \\
\hline On-peak Summer & $\begin{array}{l}1.589 \\
\text { cents }\end{array}$ & 1.550 cents & $\begin{array}{l}1.120 \\
\text { cents }\end{array}$ & 1.075 cents & 1.071 cents \\
\hline On-peak Winter & $\begin{array}{l}1.392 \\
\text { cents }\end{array}$ & 1.363 cents & $\begin{array}{l}1.012 \\
\text { cents }\end{array}$ & -- & -- \\
\hline $\begin{array}{l}\text { Semi-peak } \\
\text { Summer }\end{array}$ & $\begin{array}{l}1.313 \\
\text { cents }\end{array}$ & 1.284 cents & -- & -- & -- \\
\hline Semi-peak Winter & $\begin{array}{l}1.226 \\
\text { cents }\end{array}$ & 1.203 cents & -- & -- & -- \\
\hline Off-peak Summer & $\begin{array}{l}1.036 \\
\text { cents }\end{array}$ & 1.025 cents & -- & -- & -- \\
\hline Off-peak Winter & $\begin{array}{l}1.041 \\
\text { cents }\end{array}$ & 1.030 cents & -- & -- & -- \\
\hline
\end{tabular}

*Power Factor - a clause in a rate schedule providing for an adjustment in the billing in case the power factor varies from a specified figure or range (e.g. $85 \%)$. Power factor $=$ ratio of the real power $(\mathrm{KW})$ to the total apparent power (KVA).

IV. A meter is required.

\section{Sempra San Diego Gas \& Electric variations}

General Service - Small Time Metered

Schedule A-TOU

General Service - Time Metered - Optional

Schedule AY-TOU

General Service - Time Metered - Optional

Schedule A6-TOU

General Service - Variable Time-of-Use 1

Schedule A-V1

General Service - Variable Time-of-Use 2

Schedule A-V2 


\section{Sempra San Diego Gas \& Electric (commercial/industrial)}

\section{Scheduled Load Reduction Program \\ Commercial/Industrial Schedule SLRP (information taken from rate schedule)}

I. This program allows the customer to schedule the amount of load they are willing to reduce during periods the customer selects (up to three periods can be selected Mondy through Friday) between June 1 and September 30. The customer must have an average monthly demand of at least $100 \mathrm{~kW}$ and be able to reduce total load by $15 \%$ or $100 \mathrm{~kW}--$ whichever is greater.

II. 1 participant

III. A monthly credit of 10 cents/kWh will be paid for the amount of load reduced during the selected periods. There is no penalty for not reducing load, however, customers can be removed from the program for three failures to curtail within 12 months. Additionally, monthly incentives will be lost if load shifting to the on-peak period occurs.

The benefit of this program is that the customer will receive upgraded metering equipment at no cost to help monitor energy use.

IV. A meter is required. The utility provides a meter and installs it at no cost to the customer.

\section{Pacific Gas \& Electric (commercial/industrial) \\ Scheduled Load Reduction Program \\ Commercial/Industrial Schedule E-SLRP (information taken from rate schedule)}

I. This program is for customers with a minimum $100 \mathrm{~kW}$ demand and above who agree to reduce 15 percent of their average monthly load demand during pre-scheduled weekdays and time periods throughout the summer season (Jun 1-Sept 30). There are three four-hour time periods targeted:

Option A occurs from 8 am - noon M-F;

Option B occurs from noon -4 pm M-F;

Option C occurs from 4 pm - 8 pm M-F.

Customers are expected to curtail their load once each week for each time period, which they specify in advance. Loads cannot be shifted to an on-peak period of day. This program is also for customers who can shift their operations to the off-peak period while curtailing load during one or all of the four-hour time periods of the program between the hours of 8 am $-8 \mathrm{pm}$.

II. Number of participants is not available.

III. Pricing rate is determined by tracking a baseline average of the previous 10-day usage during a selected time period before participation in the program can begin and excluding days when the customer is paid to reduce load.

The benefit is that customers will receive credit on their bill in the amount of 10 cents per/kWh.

IV. A meter is required. The utility pays for and installs the meter at no cost. 


\section{Pacific Gas \& Electric (agricultural)}

Agricultural Power Schedule AG-4 (information taken from rate schedule)

I. This program is for customers who run 24 hours per day or who can minimize electric use summer weekdays between noon and $6 \mathrm{pm}$. A customer must use 70 percent of energy for agricultural end-uses and be served under rate schedules A, B, C, D, E, or F. Hours vary by rate schedule chosen and three time periods affect price: on-peak, partial-peak, and off-peak hours -- depending on the season. There are two seasons: Summer (May 1 - Oct 31) and Winter (Nov 1 - April 30).

II. Number of participants is not available.

III.

\begin{tabular}{|c|c|c|c|c|c|c|}
\hline & \multicolumn{2}{|c|}{ Rate A/D } & \multicolumn{2}{|c|}{ Rate B/E } & \multicolumn{2}{|c|}{ Rate $\mathrm{C} / \mathrm{F}$} \\
\hline & Summer & Winter & Summer & Winter & Summer & Winter \\
\hline \multicolumn{7}{|l|}{$\begin{array}{l}\text { Energy charge } \\
\$ / \mathbf{k W h} / \text { month }\end{array}$} \\
\hline Peak & 32 cents & -- & 20 cents & -- & 8 cents & -- \\
\hline Partial & -- & 7 cents & -- & 7 cents & 6 cents & 8 cents \\
\hline Off & 6 cents & 5 cents & 6 cents & 5 cents & 5 cents & 7 cents \\
\hline \multicolumn{7}{|l|}{ Demand charges: } \\
\hline $\begin{array}{l}\text { /horsepower of } \\
\text { connected load }\end{array}$ & $\$ 2.40$ & $\$ 2.20$ & -- & - & -- & - \\
\hline $\begin{array}{l}\text { /kW seasonal } \\
\text { demand }\end{array}$ & -- & -- & $\$ 2.90$ & $\$ 1.75$ & -- & -- \\
\hline $\begin{array}{l}\text { /kW maximum } \\
\text { peak-period }\end{array}$ & -- & -- & $\$ 2.75$ & $\mathrm{~N} / \mathrm{A}$ & $\$ 6.25$ & $\mathrm{~N} / \mathrm{A}$ \\
\hline $\begin{array}{l}\text { /kW maximum } \\
\text { partial-peak }\end{array}$ & -- & -- & -- & -- & $\$ 4.50$ & 40 cents \\
\hline $\begin{array}{l}\text { /kW } \\
\text { off-peak seasonal }\end{array}$ & -- & -- & -- & -- & $\$ 1.50$ & 20 cents \\
\hline *Voltage discount & 40 cents & 30 cents & 40 cents & 30 cents & 40 cents & 30 cents \\
\hline
\end{tabular}

*Voltage discount - the discount applied to energy charges is calculated by taking the base rate energy charge multiplied by the percentage for service delivered and metered at a variety of voltages (for example $2 \mathrm{kV}$ through $50 \mathrm{kV}$ and greater than $50 \mathrm{kV}$.)

The benefit to the customer is shifting energy use to lower price time periods.

IV. A meter is required. The utility will provide a meter if one does not already exist, but the customer must pay an installation charge. Customers with meters must pay a processing charge each time they establish service on this schedule or change any option on this schedule.

\begin{tabular}{|l|l|l|l|}
\hline Charges for meters: & Rate A & Rate D & Rate B,C,E,F \\
\hline $\begin{array}{l}\text { Customer charge } \\
\text { /meter/month }\end{array}$ & $\$ 12.00$ & $\$ 12.00$ & $\$ 16.00$ \\
\hline $\begin{array}{l}\text { Meter charge } \\
\text { /meter/month }\end{array}$ & $\$ 6.80$ & $\$ 2.00$ & $\$ 7.20$ \\
\hline $\begin{array}{l}\text { Installation charge } \\
\text { (one-time charge/meter) }\end{array}$ & $\$ 441.00$ & $\$ 441.00$ & $\$ 441.00$ \\
\hline $\begin{array}{l}\text { Processing charge } \\
\text { (one-time charge/meter) }\end{array}$ & $\$ 85.00$ & $\$ 85.00$ & $\$ 85.00$ \\
\hline
\end{tabular}




\section{$\underline{\text { Pacific Gas \& Electric Agricultural variations }}$}

\section{Agricultural Power Schedule R - Split-Week TOU}

This service is for customers who, during summer, need up to four consecutive days (including two weekdays plus Saturday and Sunday) when they can use electricity at any time of day, who can eliminate use from noon to $6 \mathrm{pm}$ on the three remaining weekdays, and who use 70 percent or more for agricultural purposes. Hours vary by rate schedule chosen and three time periods affect price: on-peak, partial-peak, and off-peak hours -- depending on the season. There are two seasons: Summer (May 1 - Oct 31) and Winter (Nov 1 - April 30).

\section{Agricultural Power Schedule V - Short-Peak TOU}

This service is for customers who can eliminate electric use summer weekdays during any one of these times: noon to $4 \mathrm{pm}, 1 \mathrm{pm}$ to $5 \mathrm{pm}$, or $2 \mathrm{pm}$ to $6 \mathrm{pm}$, and who use 70 percent or more for agricultural purposes. Hours vary by rate schedule chosen and three time periods affect price: on-peak, partial-peak, and off-peak hours -- depending on the season. There are two seasons: Summer (May 1 - Oct 31) and Winter (Nov 1 - April 30).

\section{Agricultural Power Schedule 5 - Large TOU}

This service is for customers with high annual operating hours (generally over 1,200) who run 24 hours per day or can minimize electric use summer weekdays between noon and $6 \mathrm{pm}$, and who use 70 percent or more for agricultural purposes. Hours vary by rate schedule chosen and three time periods affect price: on-peak, partial-peak, and off-peak hours -depending on the season. There are two seasons: Summer (May 1 - Oct 31) and Winter (Nov 1 - April 30).

\section{Agricultural Power Schedule 7 - Experimental Tiered TOU}

This service is for customers whose electric use varies widely from month to month or year to year and who use 70 percent or more for agricultural purposes. Hours vary by rate schedule chosen and three time periods affect price: on-peak, partial-peak, and off-peak hours -- depending on the season. There are two seasons: Summer (May 1 - Oct 31) and Winter (Nov 1 - April 30). This is a two-tiered rate schedule that automatically bills customers at Tier 1 for low (less than) 200 monthly operating hours and Tier 2 for high (greater than) 200 monthly operating hours.

\section{Pacific Gas \& Electric (commercial/industrial)}

Commercial/Industrial Schedule E-19 (information taken from rate schedule)

I. Customers on this voluntary schedule must have a demand that exceeds $500 \mathrm{~kW}$ for at least three consecutive months during the most recent 12-month period. This service includes a higher customer charge than Schedule A-6, lower energy charges than Schedule A-6, and an additional charge for demand $(\mathrm{kW})$. Summer service is May 1 - Oct 31. Winter service is Nov $1-$ Apr 30. Summer peak hours are noon -6 pm M-F. Summer partial-peak hours are 8:30 am to noon and $6 \mathrm{pm}$ to 9:30 pm M-F (except holidays). Summer off-peak hours are 9:30 pm to 8:30 am M-F and all other weekend and holiday hours. Winter partial-peak hours are 8:30 am to 9:30 pm M-F (except holidays). Winter off-peak hours are 9:30 pm to 8:30 am M-F (except holidays) and all day Saturday and Sunday.

II. Number of participants is not available. 
III.

\begin{tabular}{|l|l|l|l|l|}
\hline $\begin{array}{l}\text { Service } \\
\text { voltages }\end{array}$ & \multicolumn{2}{|c|}{ Secondary } & \multicolumn{2}{c|}{ Primary } \\
\hline & summer & winter & summer & winter \\
\hline $\begin{array}{l}\text { Energy } \\
\$ / \text { kWh }\end{array}$ & & & & \\
\hline Peak & 8 cents & N/A & 6 cents & N/A \\
\hline Partial-peak & 5 cents & 6 cents & 4 cents & 5 cents \\
\hline Off-peak & 5 cents & 5 cents & 4 cents & 4 cents \\
\hline $\begin{array}{l}\text { Demand } \\
\text { kW }\end{array}$ & & & & \\
\hline Max Peak & $\$ 13.35$ & N/A & $\$ 11.80$ & N/A \\
\hline $\begin{array}{l}\text { Max Partial- } \\
\text { peak }\end{array}$ & $\$ 3.70$ & $\$ 3.65$ & $\$ 2.65$ & $\$ 2.65$ \\
\hline Off-peak & -- & -- & -- & -- \\
\hline Maximum & $\$ 2.55$ & $\$ 2.55$ & $\$ 2.55$ & $\$ 2.55$ \\
\hline
\end{tabular}

The benefit for customers is in shifting energy usage to lower price hours.

IV. A meter is required. The utility pays for and installs the meter. There are associated costs to the customer.

\begin{tabular}{|l|l|l|l|l|l|l|}
\hline $\begin{array}{l}\text { Meter } \\
\text { Charges }\end{array}$ & \multicolumn{3}{|c|}{ Current meter in place } & \multicolumn{3}{c|}{ No-Meter previously } \\
\hline $\begin{array}{l}\text { Service } \\
\text { voltages }\end{array}$ & Primary & Secondary & Transmission & Primary & Secondary & Transmission \\
\hline $\begin{array}{l}\text { Process } \\
\text { charge }\end{array}$ & $\begin{array}{l}\$ 87- \\
1 \text { time }\end{array}$ & $\begin{array}{l}\$ 87- \\
1 \text { time }\end{array}$ & $\begin{array}{l}\$ 87- \\
1 \text { time }\end{array}$ & -- & -- & -- \\
\hline $\begin{array}{l}\text { Install } \\
\text { charge }\end{array}$ & -- & -- & -- & $\begin{array}{l}\$ 443- \\
1 \text { time }\end{array}$ & $\begin{array}{l}\$ 443- \\
1 \text { time }\end{array}$ & $\begin{array}{l}\$ 443- \\
1 \text { time }\end{array}$ \\
\hline $\begin{array}{l}\text { Customer } \\
\text { charge } \\
\text { /meter } \\
\text { /month }\end{array}$ & $\$ 140$ & $\$ 175$ & $\$ 610$ & $\$ 76.20$ & $\$ 76.20$ & $\$ 76.20$ \\
\hline $\begin{array}{l}* \text { Summer } \\
\text { peak rate } \\
\text { limiter } \\
\$ / k W h\end{array}$ & -- & -- & -- & 84.937 & 97.773 cents & 58.676 cents \\
\hline $\begin{array}{l}\text { *Summer } \\
\text { average } \\
\text { rate } \\
\text { limiter } \\
\$ \text { \$kWh }\end{array}$ & -- & -- & -- & 14 cents & 14 cents & N/A \\
\hline
\end{tabular}

*Peak-period Rate Limiter - for customers at any voltage service level, summer bills will be reduced, if necessary, so that the average rate paid for all on-peak demand and energy charges during a summer peak period does not exceed the peak-period rate limiter shown on this schedule.

**Average Rate Limiter - for customers taking service in the secondary or primary voltage class, summer bills will be reduced, if necessary, so that the average rate paid for all demand and energy charges does not exceed the average rate limiter shown on this schedule.

\section{Pacific Gas \& Electric (commercial/industrial)}

Commercial/Industrial Schedule A-6 (information taken from rate schedule)

I. The voluntary program applies to customers who use service for only part of the year. It is not available to customers whose billing demand exceeds $499 \mathrm{~kW}$ for three consecutive months. The summer rate is May 1 - Oct 31. The winter rate is Nov $1-$ April 30. Summer peak hours are noon to $6 \mathrm{pm}$ M-F. Summer partial-peak hours are 8:30 am to noon and $6 \mathrm{pm}$ to 9:30 pm M-F (except holidays). Summer off-peak 
hours are 9:30 pm to 8:30 am M-F and all day Saturday, Sunday, and holidays.

Winter partial-peak hours are 8:30 am to 9:30 pm M-F. Winter off-peak hours are 9:30 pm

to 8:30 am M-F and all day Saturday, Sunday, and holidays.

II. Number of participants is not available.

III.

\begin{tabular}{|l|l|l|}
\hline & Summer & Winter \\
\hline Energy charge \$/kWh & & \\
\hline On-Peak & 23 cents & -- \\
\hline Partial-Peak & 10 cents & 11.562 cents \\
\hline Off-Peak & 5 cents & 7.169 cents \\
\hline
\end{tabular}

The benefit is lower rates for customers who are able to shift their energy usage to off-peak periods.

IV. A meter is required. The utility pays for and installs the meter. There are associated costs to the customer.

\begin{tabular}{|l|l|l|l|l|}
\hline $\begin{array}{l}\text { Charges for } \\
\text { meters }\end{array}$ & $\begin{array}{l}\text { Current } \\
\text { meter }\end{array}$ & $\begin{array}{l}\text { Single-phase } \\
\text { meter }\end{array}$ & $\begin{array}{l}\text { Multi-phase } \\
\text { meter }\end{array}$ & $\begin{array}{l}\text { No-meter } \\
\text { previously }\end{array}$ \\
\hline Processing charge & $\$ 87-1$ time & -- & -- & -- \\
\hline Installation charge & -- & -- & -- & $\$ 443-1$ time \\
\hline $\begin{array}{l}\text { Monthly use } \\
\text { charge }\end{array}$ & $\$ 6.80$ & -- & -- & $\$ 2.00$ \\
\hline $\begin{array}{l}\text { Customer } \\
\text { charge/month }\end{array}$ & -- & $\$ 8.10$ & $\$ 12.00$ & -- \\
\hline
\end{tabular}

\section{Pacific Gas \& Electric (residential)}

Residential Schedule E-7 (information taken from rate schedule)

I. This program is good for customers who use electricity during evenings, nights, and weekends. For example, for customers who use much of their electricity at times other than noon to 6 pm weekdays (peak usage). Customers receive a baseline monetary credit if they reach a minimum level of kWh energy usage per day. Rates vary by season and according to the time of day the electricity is used. Rates are lowest in the off-peak hours between 9:30 pm and 8:30 am weekdays and all day on weekends and holidays. There are two seasons: Summer (May 1 - Oct 31) and Winter (Nov 1 - April 30).

II. Number of participants is not available.

III.

\begin{tabular}{|l|l|l|}
\hline & summer & winter \\
\hline On-Peak $\mathbf{\$} \mathbf{k W h} / \mathbf{m o n t h}$ & 31.524 cents & 11.636 cents \\
\hline Off-Peak $\mathbf{k W h} / \mathbf{m o n t h}$ & 8.515 cents & 8.851 cents \\
\hline $\begin{array}{l}\text { Baseline credit } \mathbf{\$} \mathbf{k W h} \text { of baseline } \\
\text { use }\end{array}$ & 1.732 cents & 1.732 cents \\
\hline
\end{tabular}

The benefit is lower rates for customers who use most of their electricity during off-peak periods.

IV. A meter is required. The utility pays for and installs the meter. There are associated costs to the customer.

\begin{tabular}{|l|l|l|}
\hline Meter Charges & Current meter & No meter previously \\
\hline $\begin{array}{l}\text { Customer charge } \\
\text { /meter/day }\end{array}$ & 12.813 cents & 4.270 cents \\
\hline $\begin{array}{l}\text { Installation } \\
\text { charge/meter }\end{array}$ & -- & $\$ 277.00-1$ time \\
\hline
\end{tabular}


\begin{tabular}{|l|l} 
Minimum energy charge & 16.427 cents
\end{tabular}

16.427 cents /meter/day 


\section{Tucson Electric (commercial/industrial)}

Commercial/Industrial Schedule GS-76 (information taken from rate schedule)

I. This service is limited to either an aggregate customer total of $30 \mathrm{MW}$ or an aggregate customer total of 130,000,000 $\mathrm{kWh}$ annually, whichever total is reached first. Various plans are available with this program that apply to energy pricing during different times of the day and different seasons. Summer on-peak hours are (1-6 pm M-F). Summer shoulder hours are (6-8 pm M-F). Winter on-peak hours are (7- 11 am and

6-9 pm M-F). All holidays and other hours are considered off-peak. There are two seasons: Summer (May-Oct) and Winter (Nov-Apr). Three pricing periods apply on-peak, shoulder-peak, and off-peak.

II. $20 \%$ participation out of 400 customers--all commercial programs

III.

\begin{tabular}{|c|c|c|c|c|c|c|}
\hline & \multicolumn{3}{|l|}{ Summer } & \multicolumn{3}{|l|}{ Winter } \\
\hline & On & Shoulder & Off & On & Shoulder & Off \\
\hline $\begin{array}{l}\text { Large Comm. } \\
\text { Energy charge } \\
\$ / \mathbf{k W h}\end{array}$ & $\begin{array}{l}5.8805 \\
\text { cents }\end{array}$ & $\begin{array}{l}4.9005 \\
\text { cents }\end{array}$ & $\begin{array}{l}4.1654 \\
\text { cents }\end{array}$ & $\begin{array}{l}5.8806 \\
\text { cents }\end{array}$ & -- & $\begin{array}{l}4.1654 \\
\text { cents }\end{array}$ \\
\hline $\begin{array}{l}\text { Large Comm. } \\
\text { Demand } \\
\text { charge } \\
\$ / \mathbf{k W}\end{array}$ & $\$ 10.95$ & $\$ 7.23$ & $\$ 5.40$ & $\$ 8.99$ & -- & $\$ 4.42$ \\
\hline $\begin{array}{l}\text { Large GS } \\
\text { month charge }\end{array}$ & $\$ 98.01$ & $\$ 98.01$ & $\$ 98.01$ & $\$ 98.01$ & $\$ 98.01$ & $\$ 98.01$ \\
\hline $\begin{array}{l}\text { Large GS } \\
\text { energy charge } \\
\$ / \mathbf{k W h}\end{array}$ & $\begin{array}{l}6.9587 \\
\text { cents }\end{array}$ & $\begin{array}{l}6.5667 \\
\text { cents }\end{array}$ & $\begin{array}{l}6.1746 \\
\text { cents }\end{array}$ & $\begin{array}{l}6.5667 \\
\text { cents }\end{array}$ & -- & $\begin{array}{l}5.7826 \\
\text { cents }\end{array}$ \\
\hline $\begin{array}{l}\text { Large GS } \\
\text { demand } \\
\text { charge } \$ / \mathrm{kW}\end{array}$ & $\$ 7.50$ & $\$ 4.96$ & $\$ 3.75$ & $\$ 4.96$ & -- & $\$ 2.48$ \\
\hline $\begin{array}{l}\text { General } \\
\text { Commercial } \\
\text { Service/month- } \\
\text { single phase } \\
\text { meter service }\end{array}$ & $\$ 6.78$ & $\$ 6.78$ & $\$ 6.78$ & $\$ 6.78$ & $\$ 6.78$ & $\$ 6.78$ \\
\hline$\$ / \mathbf{k W h}$ & $\begin{array}{l}22.2943 \\
\text { cents }\end{array}$ & $\begin{array}{l}14.0551 \\
\text { cents }\end{array}$ & $\begin{array}{l}6.7853 \\
\text { cents }\end{array}$ & $\begin{array}{l}15.0244 \\
\text { cents }\end{array}$ & -- & $\begin{array}{l}5.3312 \\
\text { cents }\end{array}$ \\
\hline
\end{tabular}

The benefit for customers is lower prices in off-peak hours.

IV. A meter is required. The utility pays for equipment and installation. A minimum term of one year participation is required. An additional charge of \$7.36 per month shall apply to customers receiving service using a three-phase meter.

\section{Tucson Electric (residential)}

Residential Schedule R-70 (information taken from rate schedule)

I. This service is applicable to customers with a single-phase meter only. The plan charges different prices for energy during different times of the day and different seasons. Three time periods apply - on-peak, shoulder-peak, and off-peak. There are two seasons: Summer (May-Oct) and Winter (Nov-Apr). All holidays and weekends are considered off-peak. Summer on-peak hours are (1 pm-6 pm). Summer shoulderpeak hours are $(6 \mathrm{pm}-8 \mathrm{pm})$. Summer off-peak hours are $(8 \mathrm{pm}-1 \mathrm{pm})$. Winter on- 
peak hours are (7-11 am and 6-9 pm). Winter shoulder-peak hours do not apply.

Winter off-peak hours are (9 pm -7 am and $11 \mathrm{am}-6 \mathrm{pm})$.

II. 941 participants

III.

\begin{tabular}{|l|l|l|}
\hline & Summer & Winter \\
\hline Customer charge/month & $\$ 6.78$ & $\$ 6.78$ \\
\hline On-Peak \$/kWh & 18.4171 cents & 12.6011 cents \\
\hline Shoulder-Peak \$/kWh & 11.6318 cents & N/A \\
\hline Off -Peak \$/kWh & 5.8160 cents & 4.3619 cents \\
\hline
\end{tabular}

The benefit is for customers who shift energy consumption to off-peak hours.

IV. A meter is required. Customers are required to participate for no less than 1 year. The utility pays for equipment and installation.

\section{$\underline{\text { Tucson Electric Time of Use variations }}$}

Residential Schedule No. 21 (Frozen)

Large General Service Schedule No. 85A

Large General Service Schedule No. 85 (Frozen)

Large Light and Power Schedule No. 90A

Large Light and Power Schedule No. 90 (Frozen)

\section{Portland General Electric (commercial/industrial)}

Commercial/Industrial Schedule 83 (information taken from rate schedule)

I. This schedule will work best for businesses that use electricity late at night or on weekends. There are two seasonal periods: Summer (May 1- Oct 31) and Winter (Nov 1 - April 30). Commercial schedule 83 peak hours are between 6 am and 10 pm Monday-Saturday. Off-peak hours are between 10 pm and 6 am MondaySaturday and all day Sunday.

II. There are 237 participants representing 3 commercial schedules.

III. There are four commercial tariff rates associated with this schedule. Pricing is divided into three different categories as it applies to delivery voltage: secondary, primary, and sub-transmission.

\begin{tabular}{|l|l|l|l|}
\hline Delivery Voltage & Primary & Secondary & Sub-transmission \\
\hline Charges: & & & \\
\hline $\begin{array}{l}\text { single-phase } \\
\text { service/month }\end{array}$ & $\$ 150$ & $\$ 20$ & $\$ 500$ \\
\hline $\begin{array}{l}\text { three-phase } \\
\text { service/month }\end{array}$ & -- & $\$ 25$ & -- \\
\hline $\begin{array}{l}\text { Transmission service } \\
\text { charge/month/kW }\end{array}$ & 78 cents & 78 cents & 78 cents \\
\hline $\begin{array}{l}\text { Distribution charge } \\
\text { /kW facility capacity }\end{array}$ & $\$ 1.65$ & $\$ 2.27$ & 32 cents \\
\hline $\begin{array}{l}\text { Monthly demand } \\
\text { charge /kW }\end{array}$ & -- & -- & -- \\
\hline \multicolumn{1}{|c|}{$1^{\text {st } 30 \mathrm{~kW}}$} & $\$ 1.89$ & $\$ 0.56$ & $\$ 1.05$ \\
\hline Over 30 kW & $\$ 1.89$ & $\$ 1.89$ & $\$ 1.05$ \\
\hline Energy charge & -- & -- & -- \\
\hline
\end{tabular}




\begin{tabular}{|l|l|l|l|}
\hline \$/kWh & & & \\
\hline $\begin{array}{l}\text { Less than or equal to } \\
1000 \mathrm{~kW} \text { facility } \\
\text { capacity }\end{array}$ & $\begin{array}{l}3.869 \\
\text { cents }\end{array}$ & 4.072 cents & -- \\
\hline $\begin{array}{l}\text { Greater than or equal } \\
\text { to } 1000 \mathrm{~kW} \text { facility } \\
\text { capacity }\end{array}$ & -- & -- & -- \\
\hline On-peak $(\$ / \mathrm{kWh})$ & $\begin{array}{l}4.255 \\
\text { cents }\end{array}$ & 4.419 cents & 4.186 cents \\
\hline Off-peak $(\$ / \mathrm{kWh})$ & $\begin{array}{l}3.279 \\
\text { cents }\end{array}$ & 3.410 cents & 3.219 cents \\
\hline $\begin{array}{l}\text { System Usage charge } \\
\mathbf{\$ / k W h}\end{array}$ & .354 cents & .485 cents & .257 cents \\
\hline
\end{tabular}

The benefit is to large commercial customers who can significantly shift their energy use to get a lower price in the off-peak period.

IV. A meter is required. Customers are required to participate for one year in order to receive credit. The utility pays for the meters and the cost of installation. The customer pays a monthly use fee.

\section{Portland General Electric (residential)}

Residential Schedule 7 and Small Non-Residential Schedule 32 ((information provided by Jack Breen, OR PUC)

I. In this schedule, pricing is divided into three different price categories for three different parts of the day (on-peak, mid-peak, and off-peak). This program applies to two seasonal periods: Summer (May 1- Oct 31) and Winter (Nov 1 - April 30). Summer peak hours are between $3 \mathrm{pm}-8 \mathrm{pm}$ Monday-Friday. Winter peak hours are between $6 \mathrm{am}-10$ am and 5-8 pm Monday-Friday. Summer mid-peak hours are between 6 am -3 pm and 8 pm -10 pm Mon-Fri, and 6 am -10 pm Saturdays.

Winter mid-peak hours are $10 \mathrm{am}-5 \mathrm{pm}$ and 8-10 pm Monday-Friday and $6 \mathrm{am}-$ $10 \mathrm{pm}$ Saturdays. Summer off-peak hours are between $10 \mathrm{pm}-6$ am everyday and $6 \mathrm{am}-10 \mathrm{pm}$ Sundays and holidays. Winter off-peak hours are $10 \mathrm{pm}-6 \mathrm{am}$ everyday and $6 \mathrm{am}-10 \mathrm{pm}$ Sundays and holidays.

II. Number of participants as of April 1, 2002 is 1,785. Service began March 1, 2002.

III.

\begin{tabular}{|l|l|}
\hline Basic charge & $\$ 10 /$ month \\
\hline Service charge $\mathbf{\$} / \mathbf{k W h}$ & .324 cents \\
\hline Distribution charge \$/kWh & 2.272 cents \\
\hline Energy \$/kWh & \\
\hline On-peak & 7.751 cents \\
\hline Mid-peak & 4.651 cents \\
\hline Off-peak & 2.843 cents \\
\hline
\end{tabular}

\section{Small non-residential Schedule 32}

\begin{tabular}{|l|l|}
\hline Basic charge & $\$ 10 /$ month \\
\hline Service charge \$/kWh & .248 cents \\
\hline Distribution charge \$/kWh & First $5,000 \mathrm{kWh}=2.35$ cents All Add'l=.264 cents \\
\hline Energy \$/kWh & \\
\hline On-peak & 7.419 cents \\
\hline Mid-peak & 4.454 cents \\
\hline Off-peak & 2.733 cents \\
\hline
\end{tabular}


The benefit is for customers who can shift their energy use away from on-peak periods.

IV. A meter is required. Customers are required to participate for one year. Meters are provided by the utility, but the cost of installation is an additional $\$ 2$ (for single-phase meters) or $\$ 4.25$ (for three-phase meters) on the customer's monthly bill.

\section{Puget Sound Energy (residential)}

Residential Schedule 307 (information taken from rate schedule)

I. This program is for customers that pay an energy rate based on the time of day they use energy, instead of paying by a flat rate. The charge on this schedule is equal to the sum of the morning, mid-day, evening, and economy charges per customer per season. There are two seasons: (April-September) and (October-March). Four time periods apply: morning (6 am - 10 am Monday-Saturday); mid-day (10 am - 5 pm Monday-Saturday); evening ( $5 \mathrm{pm}-9 \mathrm{pm}$ Monday-Saturday); economy (9 pm - 6 am Monday-Saturday) + all hours on Sundays and holidays.

II. 270,042 participants

III. Customers on this plan receive a seasonal monetary credit on their monthly bill.

\begin{tabular}{|l|l|l|}
\hline Energy Charges \$/kWh & April-September & October-March \\
\hline Morning & 6.8258 cents & 7.5199 cents \\
\hline Mid-day & 5.9312 cents & 6.5347 cents \\
\hline Evening & 6.8258 cents & 7.5199 cents \\
\hline Economy & 5.2735 cents & 5.7793 cents \\
\hline Credit (first 600 $\mathbf{k W h})$ & $(0.8786)$ cents & $(1.4821)$ cents \\
\hline
\end{tabular}

The benefit for the customer is taking advantage of lower prices by shifting energy usage to a lower demand time period.

IV. A meter is required. The utility provides equipment and installation at no cost, but the customer pays a monthly fee.

Single phase meter charge: $\$ 5.44 /$ month

Three phase meter charge: $\$ 13.44 /$ month

\section{Puget Sound Energy (commercial/industrial)}

\section{General service}

Commercial/Industrial Schedule 324 (information taken from rate schedule)

I. This schedule is for customers with an energy demand of $50 \mathrm{~kW}$ or less, and who pay an energy rate based on the time of day they use it, instead of paying by a flat rate. The charge is equal to the sum of the morning, mid-day, evening, and economy charges per customer per season. There are two seasons: (April-September) and (October-March). There are four time periods: morning (6 am - 10 am MondaySaturday); mid-day (10 am - 5 pm Monday-Saturday); evening (5 pm - 9 pm Monday-Saturday); economy (9 pm - 6 am Monday-Saturday) + all hours on Sundays and holidays.

II. $\quad 19,589$ participants

III. Pricing is based on season and time of day, plus a monthly basic charge.

\begin{tabular}{|l|l|l|}
\hline Energy Charges \$/kWh & April-September & October-March \\
\hline Morning & 7.3288 cents & 7.5866 cents \\
\hline Mid-day & 6.4967 cents & 6.7545 cents \\
\hline
\end{tabular}




\begin{tabular}{|l|l|l|}
\hline Evening & 7.3288 cents & 7.5866 cents \\
\hline Economy & 5.8288 cents & 6.0866 cents \\
\hline Basic charge & $\$ 6.50$ single phase meter & $\$ 6.50$ single phase meter \\
/month/meter & $\$ 14.60$ three phase meter & $\$ 14.60$ three phase meter \\
\hline
\end{tabular}

The benefit for the customer is lower prices by shifting energy usage to a lower demand time period.

IV. A meter is required. The utility installs and pays for the meter at no cost, but the customer pays a monthly use fee.

\section{Puget Sound Energy Commercial/Industrial variations}

\section{Primary General Service}

Single phase or three phase metered service at the available primary distribution voltage.

\section{Large Demand General Service}

For customers with demand greater than $350 \mathrm{~kW}$.

\section{Idaho Power (irrigation)}

Irrigation Schedule 25 (Optional) (Idaho only) (information taken from rate schedule)

I. This is a 3-year pilot program for irrigation customers currently in its second year. Energy use is either in-season (June 1 - September 30) or out-of-season (October 1 May 31). Three rate periods apply in-season: on-peak, mid-peak, and off-peak. One rate period applies out-of-season. In-season on-peak hours are (1pm-9 pm) everyday. In-season mid-peak hours are (9 am-1pm) everyday. In-season off-peak hours are (9 pm-9 am) everyday.

II. The first year there were 180 participants. A total of 300 participants are expected by the end of the program - October 1, 2007.

III. The monthly charge is the sum of the Customer, TOU meter, Demand, and Energy charges.

\begin{tabular}{|c|c|c|c|c|}
\hline Delivery voltages: & \multicolumn{2}{|c|}{ Secondary service } & \multicolumn{2}{|c|}{ Transmission service } \\
\hline & In-Season & Out-of-Season & In-Season & Out-of-Season \\
\hline $\begin{array}{l}\text { Customer charge } \\
\text { /meter/month }\end{array}$ & $\$ 10.07$ & $\$ 2.50$ & $\$ 85.61$ & $\$ 2.50$ \\
\hline $\begin{array}{l}\text { TOU meter } \\
\text { charge/meter/month }\end{array}$ & $\$ 3.00$ & -- & -- & -- \\
\hline $\begin{array}{l}\text { Demand charge } \\
/ \mathbf{k W}\end{array}$ & $\$ 3.58$ & -- & $\$ 3.37$ & - \\
\hline $\begin{array}{l}\text { Energy charge } \\
\text { \$/kWh } \\
\text { all kWh }\end{array}$ & & & & \\
\hline On-Peak & 6.6969 cents & \multirow[t]{3}{*}{5.3413 cents } & 6.4528 cents & \multirow[t]{3}{*}{5.1637 cents } \\
\hline Mid-Peak & 4.5657 cents & & 4.4262 cents & \\
\hline Off-Peak & 3.1449 cents & & 3.0752 cents & \\
\hline
\end{tabular}

The benefit for the customer is shifting irrigation energy use to a time-period with lower prices.

IV. A meter is required. The utility pays for and installs the meter at no charge, but the customer pays a monthly use fee. 


\section{Sacramento Municipal Utility District (commercial/industrial)}

\section{Large General Service}

Commercial/Industrial Schedule GS-TOU1 (information taken from rate schedule)

I. This schedule is mandatory for all commercial and industrial customers whose monthly demand is $1,000 \mathrm{~kW}$ or over for three consecutive months during the preceding 12 months. Service under this schedule is subject to meter availability.

There are two seasons on this schedule: Summer (June 1 - September 30) and Winter (October 1 - May 31). Three rate periods apply to this program: super-peak, on-peak, and off-peak hours. Super-peak hours are: $2 \mathrm{pm}-8 \mathrm{pm}$ weekdays only in the summer. On-peak hours are: noon -10 pm weekdays in the winter, and noon $-2 \mathrm{pm}$ and $8 \mathrm{pm}-10 \mathrm{pm}$ weekdays in the summer. Off-peak hours are year round on Saturdays, Sundays, and holidays.

II. Number of participants is not available.

III. Three rates are associated with this schedule. Pricing is divided into three different categories as it applies to delivery voltage -- secondary, primary, and $69 \mathrm{KV}$.

\begin{tabular}{|c|c|c|c|}
\hline Delivery voltages: & Primary & Secondary & 69KV \\
\hline \multicolumn{4}{|l|}{ Winter } \\
\hline $\begin{array}{l}\text { Customer charge } \\
\text { /month/meter }\end{array}$ & $\$ 85$ & $\$ 85$ & $\$ 225.00$ \\
\hline $\begin{array}{l}\text { Facility charge } \\
\text { /kW /12 months }\end{array}$ & $\$ 3.00$ & $\$ 3.15$ & $\$ 2.40$ \\
\hline \multicolumn{4}{|l|}{ Energy charge $\$ / \mathbf{k W h}$} \\
\hline On-peak & 7.169 cents & 7.580 cents & 6.864 cents \\
\hline Off-peak & 5.385 cents & 5.815 cents & 5.243 cents \\
\hline $\begin{array}{l}\text { Surcharge /all kWh } \\
\dot{\mathrm{c}} / \mathrm{kWh}\end{array}$ & 5 cents & 5 cents & 5 cents \\
\hline \multicolumn{4}{|l|}{ Summer } \\
\hline $\begin{array}{l}\text { Customer charge } \\
\text { /month/meter }\end{array}$ & $\$ 85.00$ & $\$ 85.00$ & $\$ 225.00$ \\
\hline $\begin{array}{l}\text { Facility charge } \\
\text { /kW /12 months }\end{array}$ & $\$ 3.00$ & $\$ 3.15$ & $\$ 2.40$ \\
\hline \multicolumn{4}{|l|}{ Energy charge $\$ / \mathrm{kWh}$} \\
\hline Super-peak & 9.995 cents & 12.304 cents & 9.688 cents \\
\hline On-peak & 9.021 cents & 9.671 cents & 8.393 cents \\
\hline Off-peak & 6.812 cents & 7.552 cents & 6.687 cents \\
\hline $\begin{array}{l}\text { Surcharge /all kWh } \\
\dot{\mathrm{c}} / \mathrm{kWh}\end{array}$ & 5 cents & 5 cents & 5 cents \\
\hline
\end{tabular}

The benefit to the customer is switching to a time period with lower prices.

IV. A meter is required. The utility installs the meters, but the meter costs are recovered as part of a monthly customer charge.

\section{Sacramento Municipal Utility District Commercial/Industrial variations}

\section{Medium General Service Schedule GS-TOU2}

This schedule is mandatory for all commercial and industrial customers whose monthly demand is 500 to $999 \mathrm{~kW}$ for three consecutive months. Service is subject to meter availability. 


\section{Small General Service Schedule GS-TOU3}

This schedule is mandatory for all commercial and industrial customers whose monthly demand is $300-499 \mathrm{~kW}$ for three consecutive months. Meters will be installed as they become available for those customers who meet the criteria for this rate schedule but currently have only a demand meter. 


\section{Texas-New Mexico Power Company (commercial/industrial)}

\section{Large General Service}

Commercial/Industrial PUCT Sheet No. 4 (information taken from rate schedule)

I. This voluntary program is for customers who contract annually for service. This service is also available only to customers for which no rate other than the large general service rate is applicable. Two rate periods apply: on-peak and off-peak. On-peak hours are (Noon -8 pm weekdays). Off-peak hours are (all other hours not defined as on-peak).

II. 1 participant in 2001

III.

\begin{tabular}{|l|l|l|l|}
\hline & Monthly minimum & Distribution voltage & $\begin{array}{l}\text { Transmission } \\
\text { voltage 69kV or } \\
\text { more }\end{array}$ \\
\hline On-peak (first 100 kW) & $\$ 7.7295 / \mathrm{kW}$ & $\$ 1992.70$ & $\$ 1947.70$ \\
\hline Additional on-peak $/ \mathbf{k W}$ & $\$ 7.7295 / \mathrm{kW}$ & $\$ 17.177$ & $\$ 16.727$ \\
\hline All off-peak $\mathbf{k W} / \mathbf{k W}$ & $\$ 7.7295 / \mathrm{kW}$ & $\$ 10.117$ & -- \\
\hline All off-peak $\mathbf{k W} / \mathbf{k W h}$ & & & 9.667 cents \\
\hline All kWh $/ \mathbf{k W h}$ & -- & -- & -- \\
\hline
\end{tabular}

The benefit for the customer is to take advantage of lower rates in off-peak periods.

IV. An hourly meter is required. The utility provides a meter, but the customer must pay for installation of equipment if no meter is already present.

\section{Xcel Energy (residential)}

Residential Schedule RT (information taken from rate schedule)

I. There are two time periods on this schedule: on-peak hours are $(8 \mathrm{am}-10 \mathrm{pm}$ weekdays) and off-peak hours are (10 pm -8 am weekdays, plus all hours on weekends and holidays).

II. 0 participants

III.

\begin{tabular}{|c|c|c|}
\hline & \begin{tabular}{|l|} 
On-peak \\
\end{tabular} & Off-peak \\
\hline $\begin{array}{l}\text { Service \& facility } \\
\text { charge /meter/month } \\
\text { minimum }\end{array}$ & $\$ 23.90$ & $\$ 23.90$ \\
\hline Demand charge $/ \mathbf{k W}$ & $\$ 6.58$ & $\$ 4.57$ \\
\hline $\begin{array}{l}\text { Energy charge /month } \\
\text { all } \$ / \mathbf{k W h}\end{array}$ & 1.645 cents & 1.645 cents \\
\hline
\end{tabular}

The benefit for the customer is taking advantage of a lower demand charge by using energy during off-peak periods.

IV. A meter is required. The utility pays for and installs the meter for no charge, but the customer pays a monthly use fee.

\section{Xcel Energy (commercial)}

\section{Primary Time of Day}

Commercial/Industrial Schedule PT (information taken from rate schedule)

I. This schedule applies to electric power service supplied at primary distribution voltage. 
II. 178 participants 
III.

\begin{tabular}{|l|l|l|}
\hline & On-peak & Off-peak \\
\hline $\begin{array}{l}\text { Minimum service \& facility } \\
\text { charge /meter/month }\end{array}$ & $\$ 125.00$ & $\$ 125.00$ \\
\hline Demand charge /kW & $\$ 7.71$ & $\$ 5.36$ \\
\hline $\begin{array}{l}\text { Energy charge } \\
\text { /month \$/all kWh }\end{array}$ & 1.612 cents & 1.612 cents \\
\hline
\end{tabular}

The benefit for the customer is a lower demand charge when using energy in off-peak hours.

IV. Utility pays for and installs meter for no charge, but the customer pays a monthly use fee.

\section{$\underline{\text { Xcel Energy Commercial/Industrial variations }}$}

Transmission Time of Day

Commercial/Industrial Schedule TT

Secondary Time of Day

Commercial/Industrial Schedule ST

\section{Montana Power (commercial/industrial)}

\section{General Service -Transmission/Substation Level}

Commercial/Industrial Schedule GS-2 (information taken from rate schedule)

I. This service is for customers who get service directly from a transmission line of $50 \mathrm{kV}$ or higher. Service from November 1 to February 28/29 is billed at the winter season rate. Service from March 1 to October 31 is billed at the summer season rate. Winter on-peak hours are 6 am to 8 pm Monday through Friday. Summer on-peak hours are 10 am to $6 \mathrm{pm}$ Monday through Friday. Off-peak hours are all other hours including holidays and weekends.

II. Number of participants is not available.

III.

\begin{tabular}{|l|l|l|}
\hline Monthly Charges & \multicolumn{1}{|c|}{ Substation voltage } & \multicolumn{1}{c|}{ Transmission voltage } \\
\hline Customer charge & $\$ 194.29$ & $\$ 1,257.15$ \\
\hline Energy charge $\mathbf{( \$ \mathbf { k W h } )}$ & 1.7926 cents & 1.7816 cents \\
\hline Maximum Demand $\mathbf{( \$ \mathbf { k W } )}$ & $\$ 7.531458$ & $\$ 7.373885$ \\
\hline Peak Demand $\mathbf{( \$ \mathbf { k W } )}$ & & \\
\hline \multicolumn{1}{|c|}{ summer } & $\$ 2.576188$ & $\$ 1.776945$ \\
\hline \multicolumn{1}{|c|}{ winter } & $\$ 6.484642$ & $\$ 5.685398$ \\
\hline $\begin{array}{l}\text { Reactive Power Cost } \\
\text { Adjustment }\end{array}$ & -- & $\$ 1.14$ per Kvar per year \\
\hline
\end{tabular}

*Reactive Power Cost Adjustment - - the maximum 15-minute integrated reactive demand in kVars occurring during the month, in excess of $40 \%$ of the maximum measured 15 -minute integrated demand in kilowatts occurring during the month.

IV. A meter is required. Customers are assessed an additional peak demand rate during peak hour usage. 


\section{PacifiCorp (commercial/industrial) (California)}

\section{Large General Service}

Commercial/Industrial Schedule AT-48 (information taken from rate schedule)

I. This schedule applies to electric service loads of $500 \mathrm{~kW}$ or more, more than once in a consecutive 18-month period. It will remain in effect until the customer fails to equal or exceed $500 \mathrm{~kW}$ for a period of 36 consecutive months. There are two demand periods: summer and winter. November 1 through April 30 is the winter period. May 1 through October 31 is the summer period. The on-peak period is 6 am to $10 \mathrm{pm}$ Monday through Friday.

II. Number of participants is not available.

III.

\begin{tabular}{|l|l|}
\hline Monthly charges & Totals \\
\hline Basic Charge & $\$ 360.00$ \\
\hline Distribution demand charge/kW & $\$ 2.90$ \\
\hline Demand charge $/ \mathrm{kW}$ - summer & $\$ 2.15$ \\
\hline Demand charge $/ \mathrm{kW}$ - winter & $\$ 3.20$ \\
\hline *Reactive Power charge $/ \mathrm{kVar}$ & 60 cents \\
\hline $\begin{array}{l}\text { Energy charge } \\
\text { /kWh for all } \mathrm{kWh}\end{array}$ & 4.296 cents \\
\hline
\end{tabular}

*Reactive Power charge - the maximum 15-minute integrated reactive demand in kVars occurring during the month in excess of $40 \%$ of the maximum measured 15 -minute integrated demand in kilowatts occurring during the month.

IV. A meter is required.

\section{PacifiCorp Large General Service commercial variations}

Large General Service - 1,000kW and over

Commercial Schedules 47T, 48T, 46, 48T, 748 (Washington, Wyoming, Oregon)

\section{PacifiCorp (Utah Power \& Light) (commercial/industrial)(Idaho) \\ General Service - Distribution Voltage \\ Commercial/Industrial Schedule 36 (information taken from rate schedule)}

I. Service for customers under this optional schedule is limited to a maximum power requirement of $15,000 \mathrm{~kW}$. If a customer's load reaches a level in excess of 15,000 $\mathrm{kW}$, continued service will require special contract arrangements. The two time periods associated with this program are peak and off-peak. On-peak hours are 7 am to $10 \mathrm{pm}$, Monday through Friday. Off-peak hours are all other times, including weekends and holidays. The customer may contract for seasonal service under this schedule. A contract service period of one year is required.

II. Number of customers is not available. 


III.
\begin{tabular}{|l|l|l|}
\hline Monthly Charges & Total & Seasonal \\
\hline Customer service charge & & \\
\hline Secondary voltage (less than 2300 volts) & $\$ 51.44$ per customer & $\begin{array}{l}\$ 617.28+\text { power and } \\
\text { energy charges }\end{array}$ \\
\hline Primary voltage (2300 volts of higher) & $\$ 126.72$ per customer & $\begin{array}{l}\$ 1,520.64+\text { power } \\
\text { and energy charges }\end{array}$ \\
\hline Power Charge & & \\
\hline On-peak kW & $\$ 12.67$ per kW & \\
\hline Off-peak kW & -- & \\
\hline Energy Charge & & 3.5717 cents \\
\hline Per kWh for all kWh & & \\
\hline
\end{tabular}

IV. A meter is required.

\section{PacifiCorp - Utah Power \& Light (Idaho) (residential)}

Residential Schedule 36 ( information provided by Bill Eastlake, ID)

I. This is an optional program based on the time of day and season the energy is used.

There are two seasons: Summer (May-October) and Winter (November-April). Two rate periods apply: Summer on-peak hours are ( $8 \mathrm{am}-11 \mathrm{pm}$ Monday-Friday) and Winter on-peak hours are ( $7 \mathrm{am}-10$ pm Monday-Friday). All other hours are offpeak, including holidays.

II. $\quad 16,018$ Participants

III.

\begin{tabular}{|l|l|l|}
\hline & May-Oct & Nov-Apr \\
\hline Energy charge \$/kWh & & \\
\hline On-peak & 10.4948 cents & 8.9667 cents \\
\hline Off-peak & 3.6168 cents & 3.2991 cents \\
\hline $\begin{array}{l}\text { Minimum customer } \\
\text { service charge /month }\end{array}$ & $\$ 12.56$ & $\$ 12.56$ \\
\hline
\end{tabular}

The benefit for the customer is lower prices by shifting energy usage to a lower demand time period.

IV. A meter is required. The utility pays for and installs the meter at no cost to the customer. One year of participation is required.

\section{PacifiCorp - Utah Power \& Light (Utah) (residential)}

Residential Schedule 1 ( information provided by Jeff Burks, UT)

\section{Inverted Rate in Summer}

I. This is the default rate schedule for residential customers. A flat rate is charged October through April. A two-tiered rate is charged from May to September.

II. $\quad 564,000$ participants

III.

\begin{tabular}{|l|l|}
\hline Service charge/month & 98 cents \\
\hline $\begin{array}{l}\text { Winter all } \mathbf{k W h} \text {, Summer } \\
\text { first } \mathbf{4 0 0} \mathbf{k W h}\end{array}$ & 6.2039 cents \\
\hline Summer $>\mathbf{4 0 0 k W h}$ & 7.0866 cents \\
\hline
\end{tabular}

The benefit for the customer is a better price signal regarding the cost of electricity and, therefore, lower costs in the long run.

IV. No additional metering required. 


\section{PacifiCorp - Utah Power \& Light (Utah) (residential)}

Residential Schedule 2 (information provided by Jeff Burks, UT)

I. This is an optional program schedule.

II. 6 participants on a monthly average

III.

\begin{tabular}{|l|l|}
\hline Service charge/month & $\$ 3.74$ \\
\hline $\begin{array}{l}\text { On-peak (8 am to 10 pm M-F, } \\
\text { except holidays) }\end{array}$ & 13.4546 cents \\
\hline Off-peak (all other hours) & 4.0225 cents \\
\hline
\end{tabular}

The benefit for the customer is to shift demand to lower cost time periods and therefore reduce customer bill and long run costs.

IV. A meter is required.

\section{PacifiCorp (Utah Power \& Light) commercial variations (State of Utah)}

Demand Time of Day Schedule 6B

Energy Time of Day Schedule 6A

Demand Time of Day Small Customer Schedule 23B

Industrial High Voltage Energy Time of Day Schedule 9A

Industrial High Voltage Demand Time of Day Schedule 9B1

\section{PacifiCorp (residential) (Oregon)}

Portfolio Market-Based and Limited Rollout Supply Service

Residential Schedules 210 and 214

Service began March 1, 2002 (information provided by Jack Breen, OR PUC)

\section{New Mexico Public Service Company (residential)}

Residential Schedule 1B (information taken from rate schedule)

I. This schedule is for customers taking $120 / 240$ volt or $120 / 208$ volt single-phase service. Three-phase service is furnished under this rate schedule only from existing lines on a 12-month continuous and non-seasonal basis. The on-peak period is 8 am to

$8 \mathrm{pm}$ Monday through Friday. The off-peak period is all other times.

II. Number of participants is not available.

III. The monthly minimum charge under this schedule is the sum of the customer charge and meter charge. 


\begin{tabular}{|c|c|}
\hline Monthly Charges & Total \\
\hline Customer charge /metered account & $\$ 12.00 /$ month minimum \\
\hline Customer charge /meter & $\$ 3.45$ \\
\hline \multicolumn{2}{|l|}{ Energy charge } \\
\hline On-peak period (cents/kWh) & 11.3979 cents \\
\hline Off-peak period (cents/kWh) & 5.0151 cents \\
\hline
\end{tabular}

The benefit to the customer is shifting energy usage to off-peak periods to get a lower energy charge.

IV. A meter is required.

\section{New Mexico Public Service Company (commercial/industrial)}

\section{General Power}

Commercial/Industrial Schedule 3B (information taken from rate schedule)

I. This schedule is for customers with a capacity of no less than $50 \mathrm{~kW}$ for any three months during a continuous 12 month period, or to customers whose consumption has exceeded 15,000 kWh per month, or whose on-peak demand exceeds $50 \mathrm{~kW}$ per month for any three months in any 12-month continuous period. Participation under this schedule is required for one year. Two rate periods apply to this schedule. On-peak hours are from 8 am to 8 pm Monday through Friday (60 hours per week). Off-peak hours are all other times including Saturdays, Sundays, and holidays.

II. Number of participants is not available.

III. The monthly minimum charge under this schedule is the sum of the customer charge, the minimum demand charge, the transformer ownership credit, and any taxes or assessments. The total demand shall not be less than the highest of the following: (a) the actual metered on-peak $\mathrm{kW}$ demand, or (b) 50 percent of the highest metered on-peak kW demand during the preceding 11 months, (c) the minimum demand defined on this schedule, or (d) the contracted minimum $\mathrm{kW}$ demand should it exceed the minimum demand provided for on this schedule.

\begin{tabular}{|l|l|}
\hline Monthly Charges & Total \\
\hline $\begin{array}{l}\text { (A) Customer charge: } \\
\text { per metered account (includes first } 50 \mathrm{~kW} \text { of demand) }\end{array}$ & $\$ 200.00$ \\
\hline $\begin{array}{l}\text { (B) On-peak demand charge: } / \mathbf{k W} \\
\text { For billing demand above } 50 \mathrm{~kW} \text { during an on-peak period }\end{array}$ & $\$ 4.00$ \\
\hline $\begin{array}{l}\text { (C) Energy charge: for first } 80 \text { on-peak kWh per } \mathrm{kW} \\
\text { demand per month }\end{array}$ & 11.8712 cents \\
\hline \multicolumn{1}{|c|}{ Next 120 kWh - on-peak } & 8.9608 cents \\
\hline All Additional on-peak and all off-peak kWh per month & 3.9097 cents \\
\hline (D) Transformer Ownership Credit & $\begin{array}{l}\text { Subtract 30 cents per } \mathrm{kW} / \mathrm{month} \\
\text { from the demand charge for } \\
\text { customers receiving service at } \\
\text { distribution voltage and who supply } \\
\text { their own transformers }\end{array}$ \\
\hline (E) Power Factor Adjustment & $\begin{array}{l}\text { add 25 cents for each } \mathrm{kVar} \text { in excess } \\
\text { of the allowed } 0.48 \text { per kW of } \\
\text { demand }\end{array}$ \\
\hline (F) Special Tax Assessment Adjustment & As assessed \\
\hline
\end{tabular}

The customer benefits by getting a lower price as a greater number of kWh hours are used. 
IV. A meter is required. The utility reserves the right to install more than one meter, if deemed necessary. They also reserve the right to meter at either secondary or primary voltage. In the latter case, the metered $\mathrm{kWh}, \mathrm{kW}$ demand, and kvar shall be multiplied by 0.98 to allow for transformer losses.

\section{$\underline{\text { New Mexico Public Service Company Commercial/Industrial variations }}$}

\section{Small Power Service Schedule 2B}

For customers with consumption of either $15,000 \mathrm{kWh}$ or more per month for any three months during a continuous 12 month period or an estimated on-peak demand of $50 \mathrm{~kW}$ or more for any three months during a 12-month period.

\section{Large Power Service Schedule 4B}

For customers who contract for no less than $500 \mathrm{~kW}$ capacity.

Irrigation Service Schedule 10B

This schedule is only for irrigation pumping installations of not less than 5 HP and where service is used to irrigate three or more acres of land used principally for agricultural purposes. Service is normally at 240 or 480 volts, three-phase service at a single location. Industrial Power Service (Large Mining Customers) Schedule 5B

The service under this schedule is available to retail mining customers and shall be threephase and delivered at a transmission voltage of $115 \mathrm{kV}$, and a primary distribution voltage of $69 \mathrm{kV}$. Customers should have a capacity of no less than $10,000 \mathrm{~kW}$.

\section{New Mexico Public Service Company (government)}

\section{United States Government Schedule 4000B}

Special Contract (information taken from rate schedule)

I. This program is available only to US Government installations covered by special contract. Service is for US Government customers who contract for a minimum monthly billing demand of $10,000 \mathrm{~kW}$ or more, for a period of either one year or seven years. The remainder of the terms of service for this program are currently under dispute between the utility and the customer. There are two rate periods in this schedule: on-peak and off-peak. On-peak hours are 8 am to $8 \mathrm{pm}$ Monday through Friday (60 hours per week). Off-peak hours are all other hours, including Saturday and Sunday.

II. 1 participant

III. The monthly minimum charge under this schedule is the sum of the customer charge and the demand charge applicable to any monthly $\mathrm{kW}$ demand above $10,000 \mathrm{~kW}$. The demand for any month shall be less than the higher of the following: (a) the actual metered $\mathrm{kW}$ demand, or (b) 75 percent of the highest 
$\mathrm{kW}$ demand for that delivery point established during the preceding 11 months, or (c) the contracted minimum $\mathrm{kW}$ demand.

\begin{tabular}{|l|l|}
\hline Monthly Charges & Total \\
\hline $\begin{array}{l}\text { (A) Customer charge: } \\
\text { per metered account (includes first } 10,000 \mathrm{~kW} \\
\text { of demand) }\end{array}$ & $\$ 70,600.00$ \\
\hline $\begin{array}{l}\text { (B) On-peak demand charge: } \\
\text { For billing demand above 10,000 kW during } \\
\text { on-peak period }\end{array}$ & $\$ 7.06 / \mathrm{kW}$ \\
\hline (C) Energy charge: /kWh & \\
\hline \multicolumn{1}{|c|}{ On-peak } & 4.9915 cents \\
\hline Off-peak & 3.3037 cents \\
\hline (D) Power Factor Adjustment & add 25 cents for each kVar in excess of the allowed \\
\hline (E) Special Tax Assessment Adjustment & As assessed \\
\hline
\end{tabular}

The benefit to the customer is getting a break on the energy bill by shifting usage to time periods of lower demand.

IV. A meter is required. The utility provides the meter and installs it at no charge.

\section{Arizona Public Service (residential)}

Residential Schedule ECT1-R (information taken from rate schedule)

\section{TOU with Demand Charge}

I. This schedule is for customers taking service at single phase, 60 Hertz and one standard voltage. The on-peak period is 9 am to $9 \mathrm{pm}$ Monday through Friday. The off-peak period is all other hours.

II. $\quad 42,000$ participants.

III. The monthly minimum charge under this schedule is the basic monthly service charge.

\begin{tabular}{|l|l|l|}
\hline Monthly Charges (total) & May-October (summer) & November-April (winter) \\
\hline Basic Service Charge / month & $\$ 15.00$ & $\$ 15.00$ \\
\hline $\begin{array}{l}\text { Capacity charge /kW On-Peak } \\
\text { (but not more than “....." per kWh for } \\
\text { all kWh use) }\end{array}$ & $\begin{array}{l}\$ 11.72 \\
\text { "9.376 cents" }\end{array}$ & $\begin{array}{l}\$ 8.39 \\
\text { “6.712 cents" }\end{array}$ \\
\hline per kWh on-peak & 4.729 cents & 3.743 cents \\
\hline per kWh off-peak & 2.630 cents & 2.630 cents \\
\hline
\end{tabular}

The benefit to the customer is shifting energy usage to off-peak periods to get a lower energy charge.

IV. A meter is required. The utility provides and installs the meter. Maintenance is incorporated into the rate. It is not a separate charge.

\section{Arizona Public Service (commercial/industrial)}

\section{Medium General Service}

Commercial/Industrial Schedule E-23 (information taken from rate schedule)

I. This schedule is for customers taking service at single or three phase, 60 Hertz and one standard voltage. The on-peak period is 11 am to $9 \mathrm{pm}$ Monday through Friday. The off-peak period is all other hours. 
II. $\quad 130$ participants.

III. The monthly minimum charge under this schedule is $\$ 20.00$ plus $\$ 1.65$ for each $\mathrm{kW}$ in excess of five of either the highest $\mathrm{kW}$ established during either the On- or OffPeak period during the 12 months ending with the current month or the minimum $\mathrm{kW}$ specified, whichever is the greater.

\begin{tabular}{|l|l|l|}
\hline Monthly Charges (total) & June-October (summer) & November-May (winter) \\
\hline Basic Service Charge / month & $\$ 58.00$ & $\$ 58.00$ \\
\hline $\begin{array}{l}\text { Billing Cycles /kW Demand Charge } \\
\text { On-Peak }\end{array}$ & $\$ 6.35$ & $\$ 5.76$ \\
\hline \multicolumn{1}{|c|}{ per kWh on-peak } & 8.077 cents & 7.250 cents \\
\hline \multicolumn{1}{|c|}{ per kWh off-peak } & 5.780 cents & 5.181 cents \\
\hline
\end{tabular}

IV. A meter is required. The utility provides and installs the meter. Maintenance is incorporated into the rate. It is not a separate charge. A contract period of one year is required.

\section{Arizona Public Service Time of Use Commercial/Residential variations}

Residential Service Schedule ET-1

Large General Service Schedule E-24

Extra Large General Service Schedule E-35

Small General Service Schedule E-22

Small General Service (less than 100 KW) Schedule E-21

General Service (Religious Houses of Worship) Schedule E-20

\section{Nevada Power Company (residential)}

\section{Optional Residential Service}

Schedule ORS-TOU (information provided by Carl Linvill)

I. This schedule is limited to the addition of 1,000 new customers per month on all TOU schedules. There are two seasons: Summer (June-September) and Winter (October-May). On-peak summer hours are $1 \mathrm{pm}$ to $7 \mathrm{pm}$ daily. Off-peak summer hours are $7 \mathrm{pm}-1 \mathrm{pm}$ daily. Winter hours are all other hours. Customers must participate for a minimum of one year.

II. Number of customers is not available.

III. The minimum charge for service is the sum of the customer charge, consumption charge, deferred energy accounting adjustment, and the universal energy charge.

\begin{tabular}{|c|l|}
\hline Monthly Charges & Rates \\
\hline Customer charge per meter & $\$ 6.68$ \\
\hline $\begin{array}{c}\text { Consumption Charge } \\
\text { (includes base tariff energy rate) }\end{array}$ & 5.051 cents \\
\hline Summer On-Peak period, per kWh & 14.303 cents \\
\hline Summer Off-Peak period, per kWh & 6.149 cents \\
\hline Winter All Other Periods, per kWh & 6.646 cents \\
\hline $\begin{array}{c}\text { Deferred Energy Accounting } \\
\text { Adjustment }\end{array}$ & $\$ 0.00843$ \\
\hline Universal Energy Charge (UEC) & \\
\hline All kWh per kWh & $\$ 0.00039$ \\
\hline
\end{tabular}


IV. A meter is required.

\section{Nevada Power Company (commercial)}

\section{Optional General Service}

Schedule OGS-TOU (information provided by Carl Linvill)

I. This schedule is applicable to customers where consumption of energy does not exceed 3,500 kWh. There are two seasons: Summer (June-September) and Winter (October-May). On-peak summer hours are $1 \mathrm{pm}$ to $7 \mathrm{pm}$ daily. Off-peak summer hours are $7 \mathrm{pm}-1 \mathrm{pm}$ daily. Winter hours are all other hours. Customers must participate for a minimum of one year.

II. Number of customers is not available.

III. The minimum charge for service is the sum of the customer charge, consumption charge, deferred energy accounting adjustment, and the universal energy charge.

\begin{tabular}{|c|l|}
\hline Monthly Charges & Rates \\
\hline $\begin{array}{c}\text { Customer charge per meter } \\
\text { (includes base tariff energy rate) }\end{array}$ & $\$ 11.17$ \\
\hline Summer On-Peak period, per kWh & 5.153 cents \\
\hline Summer Off-Peak period, per kWh & 14.587 cents \\
\hline Winter All Other Periods, per kWh & 5.620 cents \\
\hline $\begin{array}{c}\text { Deferred Energy Accounting } \\
\text { Adjustment }\end{array}$ & 6.814 cents \\
\hline Universal Energy Charge (UEC) & \\
\hline All kWh per kWh & $\$ 0.00972$ \\
\hline
\end{tabular}

IV. A meter is required.

\section{$\underline{\text { Nevada Power Company Time of Use variations }}$}

Large General Service Schedule OLGS-1

Optional Residential Multi-Family Schedule ORM

\section{Sierra Pacific Power Company (commercial)}

\section{Medium General Service}

Schedule No. GS-2-TOU (information taken from rate schedule)

I. This schedule is applicable for customers whose monthly metered maximum demand during any period is equal to or greater than five hundred (500) $\mathrm{kW}$ and less than one 
thousand kW. There are two seasons: Summer (June-September) and Winter (October-May). On-peak summer hours are 10:01 am to 10:00 pm daily. Off-peak summer hours are all other hours. On-peak winter hours are 5:01 pm to $10 \mathrm{pm}$ daily. Mid-peak winter hours are 7 am to 5 pm daily. Off-peak winter hours are all other hours. Customers must participate for a minimum of one year.

II. Number of customers is not available.

III. The minimum charge for service is the sum of the customer charge, demand charges, energy charges, power factor adjustment, voltage and transformer adjustment, and the universal energy charge.

\begin{tabular}{|c|l|l|}
\hline Monthly Charges & Rates & Total Energy Charge \\
\hline Customer charge per meter per month & $\$ 350.00$ & \\
\hline Demand Charge & & \\
\hline Winter On-Peak demand, per kW & $\$ 5.85$ & \\
\hline Winter Mid-Peak demand, per kW & $\$ 2.09$ & \\
\hline Summer On-Peak demand, per kW & $\$ 7.94$ & \\
\hline Energy Charges & & \\
\hline Winter & & 6.672 cents \\
\hline All On-Peak kWh, per kWh & & 6.440 cents \\
\hline + all Mid-Peak kWh, per kWh & & 5.731 cents \\
\hline + all Off-Peak kWh, per kWh & & 6.580 cents \\
\hline Summer & & 6.085 cents \\
\hline All On-Peak kWh, per kWh & & \\
\hline Plus all Off-Peak kWh, per kWh & & \\
\hline Power Factor Adjustment* & & \\
\hline $\begin{array}{c}\text { Credit (or charge) per kvarh - all } \\
\text { Kvarh less than or greater than } \\
\text { equivalent kvarh at 90 percent power } \\
\text { factor level }\end{array}$ & $\$ .0014$ & \\
\hline $\begin{array}{l}\text { Voltage and Transformer Adjustment } \\
\text { credit }\end{array}$ & & Transmission 5 percent \\
\hline Point of delivery -- Utility owned & Primary 0.00 percent & \\
\hline Point of delivery -- Customer owned & Primary 2.50 percent & Transmission 10 percent \\
\hline Opposite side - Utility owned & Primary 1.25 percent & Transmission 7.50 percent \\
\hline Opposite side - Customer owned & Primary 1.25 percent & Transmission 7.50 percent \\
\hline Universal Energy Charge (UEC) & & \\
\hline$\quad$ All kWh per kWh & $\$ 0.00039$ & \\
\hline
\end{tabular}

*Power Factor Adjustment -- a clause in a rate schedule providing for an adjustment in the billing in case the power factor varies from a specified figure or range (e.g. $90 \%)$. Power factor $=$ ratio of the real power $(\mathrm{KW})$ to the total apparent power (KVA).

IV. A meter is required. 


\section{Sierra Pacific Power Company Time of Use Commercial variations}

Optional Domestic Service Experimental Schedule OD-1-TOU

Optional General Service Experimental Schedule OGS-1-TOU

Optional Domestic Service Multi-Family Experimental Schedule ODM-1-TOU

\section{British Columbia Hydro \& Power Authority (CANADA) (commercial/industrial) General Service Time of Use Pilot Program (expired) \\ Commercial/Industrial Schedule 1267 (information provided by Denise Mullen-Dalmer)}

I. Customers on this schedule pay energy charges for each $\mathrm{kWh}$ consumed, a fixed monthly delivery charge and a $\$ 10 /$ month program charge. Participating customers select one of four energy charge options. Each of the energy charge options has a high rate for winter on-peak hours and a lower rate for all other hours. Once the customer has selected an energy charge option, the fixed monthly delivery charge is estimated such that the total annual bill will be the same under the selected TOU option as it would have been under RS 1211 if the Customer Load Profile (CLP) doesn't change. B.C. Hydro agreed to refund RS 1267 customers the difference between the electricity bill calculated under RS 1267 and the electricity bill under RS 1211 (based on actual consumption) if this difference is positive. The pilot program expired October 31, 2001.

II. This schedule was fully subscribed with 505 customers. For the 12-month period from March 31, 2000 to the end of February 2001, and the 361 customers at that time, actual electricity consumption in the winter peak hours fell by $840,679 \mathrm{kWh}$ and actual electricity consumption in other hours increased by $14,305,076 \mathrm{kWh}$. B.C. Hydro estimated customer benefits for the 12-month period at $\$ 252,108$ - $\$ 357,000$ before consideration of the revenue guarantee. Including the revenue guarantee, B.C. Hydro estimated customer benefits at \$1,595,941 (Cdn \$) for the entire 19-month period.

B.C. Hydro estimated its own loss from TOU pricing at $\$ 91,384$ for the 12 -month period. Including program costs and the revenue guarantee (for the entire period) resulted in a loss of $\$ 1,355,095$. B.C. Hydro's program evaluation indicates that it had not targeted the right customer segments and did not get the required load response. BC Hydro has not applied to make the program a permanent program.

III. Program Charge: $\$ 10.00 /$ month.

Delivery Charge: customer-specific, designed so that if the customer's load profile remains unchanged, the annual bill would remain the same under either its standard rate or the TOU rate.

Energy Charge: The energy charge options are based on the choice of either a four or an eight-hour peak period, combined with a standard or high peak price, as shown in the following table.

\begin{tabular}{|l|l|l|}
\hline Peak Period & Standard Peak Price & High Peak price \\
\hline$\underline{4 \text { hour peak }}$ & $\frac{\text { Option A }}{7 \phi \text { on-peak; } 3.5 \phi \text { off-peak }}$ & $\frac{\text { Option B }}{10 \phi \text { on-peak; } 3.3 \phi \text { off-peak }}$ \\
\hline$\underline{\text { ( hour peak }}$ & $\frac{\text { Option D }}{10 \phi \text { on-peak; 3.1 } \phi \text { off-peak }}$ \\
\hline
\end{tabular}


Peak prices only apply during non-statutory holiday weekdays from November to February.

IV. TOU meters required.

\section{British Columbia Hydro \& Power Authority (CANADA) (commercial/industrial)}

Transmission Service Time of Use Pilot Program (expired)

Commercial/Industrial Rate Schedule 1850 (information provided by Denise Mullen-Dalmer)

I. This pilot program was available to transmission service customers from January 1, 1999 through March 31, 2001, and offered power based on a two-part rate consisting of a fixed charge and an energy charge. The fixed charge is the customer's baseline load (CBL) times the RS 1821 rate and is designed to capture a customer's contribution to embedded cost. There is no demand charge for incremental energy. The monthly energy charge is the sum of the differences between the hourly actual loads and the hourly CBL priced at the TOU energy rates over the billing period. These rates were fixed by the customer's TOU contract for the term of the contract.

II. Four industrial customers participated in the Pilot program and all customers selected the three-tiered option for the winter period and the two-tiered option for the spring period.

III. A customer could choose from a menu of energy rate options for the winter period (November to February inclusive) and for the spring period (May to June inclusive). All other months are priced at Cdn 3.3 cents $/ \mathrm{kWh}$. The three winter options were based on a choice of a flat hourly profile, a two-tier peak/off-peak hourly profile or a three-tier premium peak, peak and off-peak hourly profile.

Option A for the spring rate was based on a peak rate of 3.3 cents $/ \mathrm{kWh}$ between the hours of six a.m. and ten p.m. on weekdays and Saturdays (except statutory holidays). The Off-peak rate for option A was based on an weighted average of the MidColumbia Low Load Hours (Mid-C LLH) and the Mid-C High Load Hours (HLH), plus an administrative charge and risk premiums. Option B for the spring rate was an average flat spring rate for all hours. The rate was calculated by adding the product of 3.3 cents $/ \mathrm{kWh}$ times the HLH to the product of the Option A Off-peak rate times the LLH, and dividing the sum by the total number of hours.

IV. A meter is required.

\section{Aquila Networks Canada (British Columbia) Ltd. (time-of-use-pricing)}

(information provided by Denise Mullen-Dalmer)

All of the customers taking service under this utility's time of use rates must pay the incremental meter costs and a one time $\$ 50.00(\mathrm{Cdn})$ installation fee. The incremental meter cost is refundable if the customer leaves the TOU option within three years of taking service.

Customers may also choose a load analysis service to compare charges under standard rates and TOU rates. A one-time set-up fee and $\$ 10.00$ per statement are charged for the service in addition to the TOU meter costs. Customers may also obtain specialized load analyses from the utility at a rate of $\$ 70.00$ per hour. 
The utility also offers a TOU rate - Green Power for the purchase of electricity from environmentally desirable technologies at an additional charge of $1.5 \phi / \mathrm{kWh}$ or a predetermined monthly charge that varies by rate schedule. Few, if any, customers have signed up for green power TOU rates.

All of this utility's TOU rates, On-Peak and Off-Peak Hours are as follows:

\begin{tabular}{|l|l|l|}
\hline $\begin{array}{l}\text { Winter } \\
\text { (Nov. - Feb) }\end{array}$ & On-Peak Hours: & $\begin{array}{l}7: 00 \mathrm{am}-12: 00 \mathrm{pm} \text { business days } \\
4: 00 \mathrm{pm}-10: 00 \mathrm{pm} \text { business days }\end{array}$ \\
& Off-Peak Hours & $\begin{array}{l}10: 00 \mathrm{pm}-7: 00 \text { am business days } \\
12: 00 \mathrm{pm}-4: 00 \mathrm{pm} \text { business days } \\
\text { All hours on weekends and statutory } \\
\text { holidays }\end{array}$ \\
\hline $\begin{array}{l}\text { Summer } \\
\text { (July, August) }\end{array}$ & On-Peak Hours: & $\begin{array}{l}10: 00 \mathrm{am}-9: 00 \text { pm business days } \\
9: 00 \mathrm{pm}-10: 00 \text { am } \\
\text { All hours on weekends and statutory } \\
\text { holidays }\end{array}$ \\
\hline $\begin{array}{l}\text { Shoulder } \\
\text { (all others) }\end{array}$ & Off-Peak Hours & $\begin{array}{l}6: 00 \text { am-10:00 pm Monday to Saturday } \\
10: 00 \mathrm{pm}-6: 00 \text { am }- \text { Monday to Saturday, } \\
\text { All day Sunday }\end{array}$ \\
\hline
\end{tabular}

\section{Aquila Networks Canada (British Columbia) Ltd. (residential tou)}

\section{Time-of-Use}

Residential Schedule 2 (information provided by Denise Mullen-Dalmer)

I. This program is available to residential customers including incidental motors of 5 HP or less.

II. Number of participants is not available.

III. The rates are as follows:

\section{Cdn $\mathbf{c} / \mathbf{k W} . \mathbf{h}$}

\begin{tabular}{|l|l|l|}
\hline $\begin{array}{l}\text { Winter } \\
\text { (Nov. - Feb) }\end{array}$ & On-Peak Hours: & 12.372 \\
& Off-Peak Hours & 3.101 \\
\hline $\begin{array}{l}\text { Summer } \\
\text { (July, August) }\end{array}$ & On-Peak Hours: & 11.908 \\
& Off-Peak Hours & 2.592 \\
\hline $\begin{array}{l}\text { Shoulder } \\
\text { (all others) }\end{array}$ & On-Peak Hours & 3.409 \\
& Off-Peak Hours & 2.138 \\
\hline
\end{tabular}

IV. TOU metering is required.

\section{Aquila Networks Canada (British Columbia) Ltd. (commercial/industrial)} General Service - Secondary - Time of Use 
Commercial/Industrial Schedule 22 (information provided by Denise Mullen-Dalmer)

I. Available to non-residential secondary distribution voltage customers with electrical demand of less than $500 \mathrm{~kW}$. Service is available for a minimum of 12 consecutive months.

II. Number of participants is not available.

III. The rates are as follows:

Cdn. $\mathbf{c} / \mathbf{k W} . \mathbf{h}$

\begin{tabular}{|l|l|l|}
\hline $\begin{array}{l}\text { Winter } \\
\text { (Nov. - Feb) }\end{array}$ & On-Peak Hours: & 14.813 \\
& Off-Peak Hours & 3.712 \\
\hline $\begin{array}{l}\text { Summer } \\
\text { (July, August) }\end{array}$ & On-Peak Hours: & 14.256 \\
& Off-Peak Hours & 3.079 \\
\hline $\begin{array}{l}\text { Shoulder } \\
\text { (all others) }\end{array}$ & On-Peak Hours & 4.081 \\
& Off-Peak Hours & 2.561 \\
\hline
\end{tabular}

IV. TOU metering is required.

Aquila Networks Canada (British Columbia) Ltd. (commercial/industrial)

General Service - Primary - Time of Use

Commercial/Industrial Schedule 23 (information provided by Denise Mullen-Dalmer)

I. Available to non-residential primary distribution voltage customers with electrical demand of less than $500 \mathrm{~kW}$. Service is available for a minimum of 12 consecutive months.

II. Number of participants is not available.

III. The rates are as follows:

Cdn $\mathbf{c} / \mathbf{k W} . \mathbf{h}$

\begin{tabular}{|l|l|l|}
\hline $\begin{array}{l}\text { Winter } \\
\text { (Nov. - Feb) }\end{array}$ & On-Peak Hours: & 14.185 \\
& Off-Peak Hours & 3.555 \\
\hline $\begin{array}{l}\text { Summer } \\
\text { (July, August) }\end{array}$ & On-Peak Hours: & 13.651 \\
& Off-Peak Hours & 2.950 \\
\hline $\begin{array}{l}\text { Shoulder } \\
\text { (all others) }\end{array}$ & On-Peak Hours & 3.907 \\
& Off-Peak Hours & 2.453 \\
\hline
\end{tabular}

IV. TOU metering is required.

Aquila Networks Canada (British Columbia) Ltd. (commercial/industrial)

Large General Service - Primary - Time of Use

Commercial/Industrial Schedule 32 (information provided by Denise Mullen-Dalmer)

I. Available to non-residential distribution voltage customers with electrical demand of less than $500 \mathrm{~kW}$. Service is available for a minimum of 12 consecutive months.

II. Number of participants is not available.

III. The rates are as follows: 


\begin{tabular}{|c|c|c|}
\hline \multirow[b]{2}{*}{ (Nov. - Feb) } & & \\
\hline & $\begin{array}{l}\text { On-Peak Hours: } \\
\text { Off-Peak Hours }\end{array}$ & $\begin{array}{l}13.165 \\
2.685\end{array}$ \\
\hline $\begin{array}{l}\text { Summer } \\
\text { (July, August) }\end{array}$ & $\begin{array}{l}\text { On-Peak Hours: } \\
\text { Off-Peak Hours }\end{array}$ & $\begin{array}{l}12.638 \\
2.087\end{array}$ \\
\hline $\begin{array}{l}\text { Shoulder } \\
\text { (all others) }\end{array}$ & $\begin{array}{l}\text { On-Peak Hours } \\
\text { Off-Peak Hours }\end{array}$ & $\begin{array}{l}3.033 \\
1.597\end{array}$ \\
\hline
\end{tabular}

IV. TOU metering is required.

\section{Aquila Networks Canada (British Columbia) Ltd. (commercial/industrial)}

Large General Service - Transmission - Time of Use

Commercial/Industrial Schedule 33 (information provided by Denise Mullen-Dalmer)

I. Available to industrial customers with electrical demand of 5,000 kV.A or more, served at transmission voltage Service is available for a minimum of 12 consecutive months.

II. Number of participants is not available.

III. The rates are as follows:

\section{Cdn $\mathbf{c} / \mathbf{k W} . \mathbf{h}$}

\begin{tabular}{|l|l|l|}
\hline $\begin{array}{l}\text { Winter } \\
\text { (Nov. - Feb) }\end{array}$ & On-Peak Hours: & 9.282 \\
& Off-Peak Hours & 2.630 \\
\hline $\begin{array}{l}\text { Summer } \\
\text { (July, August) }\end{array}$ & On-Peak Hours: & 12.382 \\
& Off-Peak Hours & 2.045 \\
\hline $\begin{array}{l}\text { Shoulder } \\
\text { (all others) }\end{array}$ & On-Peak Hours & 2.971 \\
& Off-Peak Hours & 1.564 \\
\hline
\end{tabular}

IV. TOU metering is required.

\section{Aquila Networks Canada (British Columbia) Ltd. (commercial/industrial)}

Wholesale Service - Primary - Time of Use

Commercial/Industrial Schedule 42 (information provided by Denise Mullen-Dalmer)

I. This service is available to non-residential distribution voltage customers with electrical demand of less than $500 \mathrm{~kW}$, for a minimum of 12 consecutive months.

II. Number of participants is not available.

III. The rates are as follows:

Cdn $\mathbf{c} / \mathbf{k W} . \mathbf{h}$

\begin{tabular}{|l|l|l|}
\hline $\begin{array}{l}\text { Winter } \\
\text { (Nov. - Feb) }\end{array}$ & On-Peak Hours: & 11.700 \\
\hline $\begin{array}{l}\text { Summer } \\
\text { (July, August) }\end{array}$ & Off-Peak Hours & 2.387 \\
\hline $\begin{array}{l}\text { Shoulder } \\
\text { (all others) }\end{array}$ & Off-Peak Hours & 11.233 \\
\hline
\end{tabular}

IV. TOU metering is required. 


\section{Aquila Networks Canada (British Columbia) Ltd. (agricultural)}

\section{Agricultural Irrigation and Drainage - Time of Use}

Irrigation Schedule 61 (information provided by Denise Mullen-Dalmer)

I. Service is available for a minimum of 12 consecutive months.

II. Number of participants is not available.

III. The rates are as follows:

\section{Cdn $\mathbf{~} / \mathbf{k W} . \mathbf{h}$}

\begin{tabular}{|l|l|l|}
\hline $\begin{array}{l}\text { Winter } \\
\text { (Nov. - Feb) }\end{array}$ & On-Peak Hours: & 9.834 \\
& Off-Peak Hours & 2.465 \\
\hline $\begin{array}{l}\text { Summer } \\
\text { (July, August) }\end{array}$ & On-Peak Hours: & 9.465 \\
& Off-Peak Hours & 2.044 \\
\hline $\begin{array}{l}\text { Shoulder } \\
\text { (all others) }\end{array}$ & On-Peak Hours & 2.709 \\
& Off-Peak Hours & 1.699 \\
\hline
\end{tabular}

IV. TOU metering is required.

\section{SaskPower (Saskatchewan, CANADA) (commercial)}

\section{General Service - Standard}

Commercial Rate Schedules E05 and E06 (information provided by Trevor Dark)

I. $\quad$ For metered non-residential and non-farm loads greater than $75 \mathrm{kV}$.A served through the utility supplied transformation and to which no other rates apply.

The recorded demand shall be the maximum $\mathrm{kV}$.A demand registered during the current month or for those services with approved time-of-day metering, the greater of the maximum $\mathrm{kV}$.A demand registered between the hours of 7 am to $10 \mathrm{pm}$ Monday through Friday excluding statutory holidays or 50 percent of the maximum $\mathrm{kV}$.A demand registered at any other time during the current month.

II. Number of participants is not available.

III.

\begin{tabular}{|l|l|l|}
\hline & URBAN & RURAL \\
\hline RATE CODE & E05 & E06 \\
\hline Basic Monthly Charge: & $\$ 22.62$ & $\$ 33.65$ \\
\hline Demand Charge: & & \\
\hline First $50 \mathrm{kV} . \mathrm{A} / \mathrm{mo}$ & 0 & 0 \\
Balance $/ \mathrm{kV} . \mathrm{A}$ & $\$ 10.92$ & $\$ 13.52$ \\
\hline Energy Charge & & \\
\hline First $16750 \mathrm{kWh} / \mathrm{mo}($ cents $/ \mathrm{kWh})$ & 7.27 cents & 7.63 cents \\
Balance $($ cents/kWh) & 4.014 cents & 3.640 cents \\
\hline
\end{tabular}

The minimum bill is the basic monthly charge plus $\$ 1.10 / \mathrm{kV}$.A of the maximum recorded demand over $50 \mathrm{kV}$.A registered over the past eleven months.

IV. A meter is required. 


\section{SaskPower (Saskatchewan, CANADA) (commercial)}

\section{General Service - Small Commercial}

Commercial Rate Schedules E75 and E76 (information provided by Trevor Dark)

I. For metered commercial and municipal loads up to $75 \mathrm{kV}$.A served through the utility supplied transformation and to which no other rates apply. For services to all Provincial and Federal Government Departments, Agencies, Boards, Commissions and Crown Corporations the General Service - Standard rates apply.

The recorded demand shall be the maximum $\mathrm{kV}$.A demand registered during the current month or for those services with approved time-of-day metering, the greater of the maximum $\mathrm{kV}$.A demand registered between the hours of 7 am to $10 \mathrm{pm}$ Monday through Friday excluding statutory holidays or 50 percent of the maximum $\mathrm{kV}$.A demand registered at any other time during the current month.

II. Number of participants is not available.

III.

\begin{tabular}{|l|l|l|}
\hline & URBAN & RURAL \\
\hline RATE CODE & E75 & E76 \\
\hline Basic Monthly Charge: & $\$ 18.34$ & $\$ 23.95$ \\
\hline Demand Charge: & & \\
\hline First $50 \mathrm{kV} . \mathrm{A} / \mathrm{mo}$ & 0 & 0 \\
Balance $/ \mathrm{kV} . \mathrm{A}$ & $\$ 10.26$ & $\$ 12.35$ \\
\hline Energy Charge & & \\
\hline First block kWh/mo. & $12,500 \mathrm{kWh}$ & $11,500 \mathrm{kWh}$ \\
First block $($ cents/kWh) & 7.77 cents & 8.58 cents \\
Balance $($ cents/kWh) & 4.020 cents & 3.678 cents \\
\hline
\end{tabular}

The minimum bill is the basic monthly charge plus $\$ 1.00 / \mathrm{kV}$.A of the maximum recorded demand over $50 \mathrm{kV}$.A registered over the past eleven months.

IV. A meter is required.

\section{SaskPower (Saskatchewan, CANADA) (industrial)}

\section{General Service - Manufacturing \& Food Processing}

Commercial Rate Schedules E65 and E66 (information provided by Trevor Dark)

I. For manufacturing facility loads served through the utility supplied transformation.

The recorded demand shall be the maximum $\mathrm{kV}$.A demand registered during the current month or for those services with approved time-of-day metering, the greater of the maximum $\mathrm{kV}$.A demand registered between the hours of $7 \mathrm{am}$ to $10 \mathrm{pm}$ Monday through Friday excluding statutory holidays or 50 percent of the maximum $\mathrm{kV}$.A demand registered at any other time during the current month.

II. Number of participants is not available. 
III.

\begin{tabular}{|l|l|l|}
\hline & URBAN & RURAL \\
\hline RATE CODE & E65 & E66 \\
\hline Basic Monthly Charge: & $\$ 20.78$ & $\$ 31.50$ \\
\hline Demand Charge: & & \\
\hline \multicolumn{1}{|l|}{ First 50 kV.A/mo } & 0 & 0 \\
Balance \$/kV.A & $\$ 11.17$ & $\$ 10.87$ \\
\hline Energy Charge & & \\
\hline First $11,500 \mathrm{kWh} / \mathrm{mo} .($ cents $/ \mathrm{kWh})$ & 7.54 cents & 7.54 cents \\
Balance $($ cents $/ \mathrm{kWh})$ & 2.646 cents & 2.704 cents \\
\hline
\end{tabular}

The minimum bill is the basic monthly charge plus $\$ 0.75 / \mathrm{kV}$.A of the maximum recorded demand over $50 \mathrm{kV}$.A registered over the past eleven months.

IV. A meter is required.

\section{SaskPower (Saskatchewan, CANADA) (commercial)}

\section{General Service - Standard}

Commercial Rate Schedules E07, E08 and E10, E12 (information provided by Trevor Dark)

I. For metered non-residential and non-farm loads greater than $75 \mathrm{kV}$.A and up to $2000 \mathrm{kV}$.A served through customer owned transformation and to which no other rates apply. The recorded demand shall be the maximum $\mathrm{kV}$.A demand registered during the current month or for those services with approved time-of-day metering, the greater of the maximum $\mathrm{kV}$.A demand registered between the hours of 7 am to $10 \mathrm{pm}$ Monday through Friday excluding statutory holidays or 50 percent of the maximum $\mathrm{kV}$.A demand registered at any other time during the current month.

II. Number of participants is not available.

III.

\begin{tabular}{|c|c|c|c|c|}
\hline & URBAN & RURAL & & \\
\hline RATE CODE & E75 & E76 & E10 & E12 \\
\hline Supply Voltage & $\begin{array}{l}25 \mathrm{kV} \text { and } \\
\text { less }\end{array}$ & $25 \mathrm{kV}$ and less & $72 \mathrm{kV}$ & $138 \mathrm{kV}$ \\
\hline $\begin{array}{l}\text { Basic Monthly } \\
\text { Charge: }\end{array}$ & $\$ 58.10$ & $\$ 86.50$ & $\$ 86.50$ & $\$ 62.50$ \\
\hline \multicolumn{5}{|l|}{ Demand Charge: } \\
\hline $\begin{array}{l}\text { First } 50 \mathrm{kV} . \mathrm{A} / \mathrm{mo} \\
\text { Balance } \$ / \mathrm{kV} . \mathrm{A}\end{array}$ & $\begin{array}{l}0 \\
\$ 10.29\end{array}$ & $\begin{array}{l}0 \\
\$ 12.54\end{array}$ & $\begin{array}{l}0 \\
\$ 4.95\end{array}$ & $\begin{array}{l}0 \\
\$ 4.75\end{array}$ \\
\hline \multicolumn{5}{|l|}{ Energy Charge } \\
\hline $\begin{array}{l}\text { First block kWh } / \mathrm{mo} \text {. } \\
\text { First block (cents } / \mathrm{kWh} \text { ) } \\
\text { Balance (cents } / \mathrm{kWh} \text { ) }\end{array}$ & $\begin{array}{l}17,750 \mathrm{kWh} \\
6.89 \text { cents } \\
4.067 \text { cents }\end{array}$ & $\begin{array}{l}11,500 \mathrm{kWh} \\
7.00 \text { cents } \\
3.550 \text { cents }\end{array}$ & $\begin{array}{l}15,750 \mathrm{kWh} \\
5.16 \text { cents } \\
3.620 \text { cents }\end{array}$ & $\begin{array}{l}18,250 \mathrm{kWh} \\
4.76 \text { cents } \\
3.470 \text { cents }\end{array}$ \\
\hline
\end{tabular}

The minimum bill is the basic monthly charge plus $\$ 0.80 / \mathrm{kV}$.A of the maximum recorded demand over $50 \mathrm{kV}$.A registered over the past eleven months.

IV. A meter is required. 
SaskPower (Saskatchewan, CANADA) (commercial)

\section{General Service - Small Commercial}

Commercial Rate Schedules E75 and E76 (information provided by Trevor Dark)

I. For metered commercial and municipal loads up to $75 \mathrm{kV}$.A served through customer owned transformation and to which no other rates apply. For services to all Provincial and Federal Government Departments, Agencies, Boards, Commissions and Crown Corporations the General Service - Standard rates apply.

The recorded demand shall be the maximum $\mathrm{kV}$.A demand registered during the current month or for those services with approved time-of-day metering, the greater of the maximum $\mathrm{kV}$.A demand registered between the hours of $7 \mathrm{am}$ to $10 \mathrm{pm}$ Monday through Friday excluding statutory holidays or 50 percent of the maximum $\mathrm{kV}$.A demand registered at any other time during the current month.

II. Number of participants is not available.

III.

\begin{tabular}{|l|l|l|}
\hline & URBAN & RURAL \\
\hline RATE CODE & E77 & E78 \\
\hline Supply Voltage & $25 \mathrm{kV} \&$ less & $25 \mathrm{kV} \&$ less \\
\hline Basic Monthly Charge: & $\$ 18.34$ & $\$ 23.95$ \\
\hline Demand Charge: & & \\
\hline \multicolumn{1}{|c|}{ First $50 \mathrm{kV} . \mathrm{A} / \mathrm{mo}$} & 0 & 0 \\
Balance $\$ \mathrm{kV} . \mathrm{A}$ & $\$ 9.89$ & $\$ 11.90$ \\
\hline Energy Charge & & \\
\hline First block $\mathrm{kWh} / \mathrm{mo}$. & $12,500 \mathrm{kWh}$ & $11,500 \mathrm{kWh}$ \\
First block $($ cents $/ \mathrm{kWh})$ & 7.77 cents & 8.58 cents \\
Balance $($ cents $/ \mathrm{kWh})$ & 4.020 cents & 3.678 cents \\
\hline
\end{tabular}

The minimum bill is the basic monthly charge plus $\$ 1.00 / \mathrm{kV}$.A of the maximum recorded demand over $50 \mathrm{kV}$.A registered over the past eleven months.

IV. A meter is required.

SaskPower (Saskatchewan, CANADA) (industrial)

General Service - Manufacturing \& Food Processing

Commercial Rate Schedules E67, E68, and E60, E69 (information provided by Trevor Dark)

I. For manufacturing facility loads up to $2000 \mathrm{kV}$.A served through customerowned transformation. The recorded demand shall be the maximum kV.A demand registered during the current month or for those services with approved time-of-day metering, the greater of the maximum $\mathrm{kV}$.A demand registered between the hours of $7 \mathrm{am}$ to $10 \mathrm{pm}$ Monday through Friday excluding statutory holidays or 50 percent of the maximum $\mathrm{kV}$.A demand registered at any other time during the current month.

II. Number of participants is not available.

III. 


\begin{tabular}{|l|l|l|l|l|}
\hline RATE CODE & E67 & E68 & E60 & E69 \\
\hline Supply Voltage & $25 \mathrm{kV}$ & $25 \mathrm{kV}$ & $72 \mathrm{kV}$ & $138 \mathrm{kV}$ \\
\hline Basic Monthly Charge: & $\$ 31.35$ & $\$ 201.90$ & $\$ 422.84$ & $\$ 757.05$ \\
\hline Demand Charge: & & & & \\
\hline First 50 kV.A/mo & 0 & 0 & 0 & 0 \\
Balance \$/kV.A & $\$ 7.45$ & $\$ 9.01$ & $\$ 3.97$ & $\$ 3.92$ \\
\hline Energy Charge & & & & \\
\hline First Block $-\mathrm{kWh} / \mathrm{mo}$ & $18,750 \mathrm{kWh}$ & $14,000 \mathrm{kWh}$ & $15,750 \mathrm{kWh}$ & $16,500 \mathrm{kWh}$ \\
First Block $($ cents/kWh) & 5.40 cents & 6.22 cents & 4.47 cents & 4.23 cents \\
Balance $($ cents $/ \mathrm{kWh})$ & 3.420 cents & 3.019 cents & 3.233 cents & 3.163 cents \\
\hline
\end{tabular}

The minimum bill is the basic monthly charge plus $\$ 0.60 / \mathrm{kV}$.A of the maximum recorded demand over $50 \mathrm{kV}$.A registered over the past eleven months.

IV. A meter is required.

\section{SaskPower (Saskatchewan, CANADA) (industrial)}

Power - Manufacturing \& Food Processing

Commercial Rate Schedules E62, E63, and E64 (information provided by Trevor Dark)

I. For manufacturing facility loads greater than $2000 \mathrm{kV}$.A and up to $15000 \mathrm{kV}$.A served through customer-owned transformation. The monthly recorded demand shall be the greater of the maximum $\mathrm{kV}$.A demand registered between the hours of 7 am to $10 \mathrm{pm}$ Monday through Friday excluding statutory holidays or 50 percent of the maximum $\mathrm{kV}$.A demand registered at any other time during the current month.

II. Number of participants is not available.

III.

\begin{tabular}{|l|l|l|l|}
\hline RATE CODE & E62 & E63 & E64 \\
\hline Supply Voltage & $25 \mathrm{kV}$ & $72 \mathrm{kV}$ & $138 \mathrm{kV}$ \\
\hline Basic Monthly Charge: & $\$ 2816.00$ & $\$ 3035.00$ & $\$ 3365.00$ \\
\hline Demand Charge: & & & \\
\hline $\begin{array}{c}\text { Per kV.A of billing demand } \\
\text { each month }\end{array}$ & $\$ 4.46$ & $\$ 2.31$ & $\$ 2.22$ \\
\hline Energy Charge & & & \\
\hline \multicolumn{1}{c}{ cents/kWh } & 3.371 cents & 3.625 cents & 3.263 cents \\
\hline
\end{tabular}

The minimum bill is the demand charge plus the basic monthly charge.

IV. A meter is required. 


\section{Demand Buyback}

Demand buyback programs are available when the customer is willing to forego using electricity at a certain predetermined price. Typically these are voluntary programs since the customer has a choice about whether and how much to participate on any particular day in response to utility requests.

\section{Sacramento Municipal Utility District (commercial/industrial)}

\section{PowerNet Program}

Commercial/Industrial (information taken from rate schedule)

I. Via an internet bidding system, the utility sets the price it will pay for load reduction. Customers then decide whether to participate. Businesses reduce energy use by raising thermostats, dimming lights, etc. There is a potential savings

of

$26 \mathrm{MW}$ (determined by number of customers).

II. There are currently 30 customers participating in this program.

III. The price the utility pays for load reduction is determined using a Trend Analysis, based on variables such as weather, prices of the past few days, pricing forecasts, etc. Revenue from the sale of diverted power is split 50/50 with the customer and is received in the form of a credit to the customers' bill.

IV. Customers need a DSL line, and must enroll in an Internet account with email or purchase a text capable pager at their expense to receive communications from the utility.

\section{Portland General Electric (commercial/industrial)}

\section{Demand Buy Back Program \\ Commercial/Industrial}

Schedule 86 (information provided by Jack Breen, OR PUC)

I. Through an interactive website, and based on estimated hourly electric savings, (this is an estimate of how much energy a certain machine(s) use based on existing and historical maintenance schedules), customers voluntarily turn off large power equipment during high price peak times. The utility aggregates the load reduction with other customers, and shares the value of that energy in the wholesale market. Reduction must be no less than $250 \mathrm{kWh}$ per meter, and load reduction is calculated based on historic baseline electricity usage.

II. 8 customers have previously taken part in load reduction and 26 are currently signed up to participate (lack of events have prohibited them from participating thus far).

III. After the Demand Buy Back event has occurred, verification of load reduction is computed using actual interval data from hourly-metered loads. An hourly credit rate 
(rate determined by subtracting the amount a customer's machine(s) drops from an average baseline figure extracted from historical usage for normal operations) is determined by the utility, and the customer is credited based on the sum of the hourly credits during an event. Each customer will receive a check within 60 days of the event. Should the customer fail to reduce a pledged amount, they are liable to the utility for the cost of electricity used rather than reduced. The program started in July 2000 , and saw a high price paid to customers of $\$ 300 \mathrm{MW} / \mathrm{hr}$ and an average price of $\$ 225 \mathrm{MW} / \mathrm{hr}$. Because of the FERC price cap at $\$ 92 \mathrm{MW} / \mathrm{hr}$ this program is no longer economically feasible.

IV. Customers must have Internet access. The utility pays to install interval metering, however, most customers already have meters in place.

\title{
Bonneville Power Administration (commercial/industrial)
}

\section{Demand Exchange Program}

Commercial/Industrial (Idaho, Montana, Oregon) (information taken from rate schedule)

I. This is a voluntary program where participants are notified, via the Internet, of hourly, one-day, and two-day-ahead price signals associated with peak load events. The utility makes the curtailment bid. Customers indicate, via the computer, their willingness to participate at the given price. The utility confirms and monitors participants' curtailment pledges.

II. $\quad 12-15$ participants, with more than $400 \mathrm{MW}$ of load, have signed up for the program.

III. The utility curtailment bids are based solely on conditions in the wholesale market, including analysis on what the value of curtailment will be. Participant compensation is received either in cash or credits to a customer's future electric bill, based on the amount of curtailment achieved and the bid price.

The benefit to the customer is cash or a credit to their future bill.

IV. Customers must have Internet access and requisite metering. Typically, participants already have the necessary metering in place, but Bonneville is willing to look into cost-sharing with customers without metering already in place.

\section{Bonneville Power Administration (commercial/industrial)}

\author{
Aluminum Smelter Buyback (Washington) \\ Commercial/Industrial (information provided per Ken Corum - Northwest Power Planning Council) \\ I. $\quad 1000 \mathrm{MW}$ of buyback \\ II. Number of participants is not available. \\ III. No other information is available. \\ IV. No other information is available.
}

\section{Eugene Water and Electric Board (commercial/industrial) \\ Commercial/Industrial (information provided per Ken Corum - Northwest Power Planning Council)}


I. In this program, the utility paid customers to reduce load compared to corresponding days in the year 2000. Customers were metered daily for on-peak and off-peak periods.

II. 29 participants

III. Reductions of more than 5 percent, compared to corresponding days and periods in 2000, were compensated at half the difference between the mid-Columbia on-peak and off-peak quotes and the customer's conventional rate.

IV. A meter was required.

\section{Springfield Utility Board (commercial/industrial)}

Commercial/Industrial Contract (information provided per Ken Corum - Northwest Power Planning Council)

I. In this program, the utility contracted with its largest industrial customer to shut down from January 1, 2001 to September 30, 2003.

II. 1 participant

III. Load reduction was for approximately $20 \mathrm{MW}$.

IV. No meter is required.

\section{Grant County PUD (irrigation)}

Irrigation (information provided per Ken Corum - Northwest Power Planning Council)

I. In this program, the utility bought out about $9 \mathrm{MW}$ of irrigation load from June through September of 2001.

II. Number of participants is not available.

III. No other information is available.

IV. No other information is available.

\section{Puget Sound Energy (commercial/industrial)}

\section{Voluntary Load Curtailment Service}

Commercial/Industrial Schedule 93 (information provided by Nick Garcia, WA)

I. This voluntary program is for customers with demand greater than 3,000 kva. Participants are notified of a curtailment opportunity, and the corresponding monetary credit that will be received for the next day's curtailment by pager or e-mail by 9:00 a.m. Participants must respond by 12 noon if they can reduce energy consumption and by how much they can reduce. If a customer accepts the offer, usage is monitored by the utility. Participants must curtail usage by a minimum of $500 \mathrm{~kW}$ over a one-hour period.

II. 19 of 547 eligible customers signed on. Best month, 4 participants, $29 \mathrm{MWhs}$ saved. 
III. Curtailment periods are determined based on market factors. The utility offers a buyback price ( 50 percent of the spot market) on a next-day basis. The customer nominates their curtailment level a day ahead on an hourly basis. If a customer reaches the agreed upon reduction, a cash credit (based on current wholesale spot market rates) for half the power cost saving, adjusted for transmission loss and current energy price, is credited on the next month's bill. Credit is determined by the following formula: ([ (Offer Price $x$ Loss Factor (transmission loss predetermined based on type of rate scheduled customer) - Base Schedule Energy Charge x Curtailed Energy] $\div 2$

The benefit to the customer for participating is the cash credit on their monthly bill.

IV. Customers must have utility metering equipment and Internet access or pager and internet-based software to allow for communication with the utility. 


\section{Puget Sound Energy (commercial/residential)}

\section{Conservation Incentive Credit Program}

Small Commercial/Residential Schedule 125 (information provided by Nick Garcia, WA)

This program is available to residential and small commercial customers. The utility offers 5 cents per $\mathrm{kWh}$ credit for load reductions over 10 percent. Twenty-seven percent of customers $(225,000$ out of 915,000$)$ met the 10 percent threshold. Best month, 98,000 MWhs saved.

\section{PacifiCorp (commercial/industrial)}

\section{Energy Exchange Program Rider}

Commercial/Industrial Schedule 71 (Idaho, Oregon, *Utah, *Washington, Wyoming)

I. This is an optional service plan for customers whose monthly demand exceeds 1,000

$\mathrm{kW}$ at least once during the last 12-month period. Customers on this schedule voluntarily reduce their electricity usage in exchange for a payment at times and at prices determined by the utility. Customers participating in an exchange event must maintain their electricity usage at a level that is below the customer's average service level for each hour during fourteen typical operational days prior to the pledged event. The utility notifies customers of the opportunity of the event via a phone connection. The customer responds using a secure Internet web site. An event may be for one or more consecutive hours and more than one event may occur in the course of one day. Prior to an event period, a customer must advise the utility as to how many hours notification the customer requires. There are three notification options: 2 hours, 3 hours, and 4 hours. Each notification option has a corresponding minimum hourly credit rate. The amount of energy exchanged shall be the difference between the customer's average service level for each hour during fourteen typical operational days prior to a pledged event, and the customer's measured load for each hour during the term of the event.

II. Number of participants is not available.

III. Customers receive an hourly credit for each hour they agree to curtail during an event. The hourly credit*** is calculated by multiplying the exchange amount $(\mathrm{kWh})$ by the hourly credit rate. The hourly credit rate** (cents/kWh) is arrived at by subtracting the customer's rate schedule energy price from the market price signal*. The exchange credit is the amount paid to the customer for the exchange event and is the sum of each hourly credit during the event. The customer will receive cash or a monetary credit on their monthly billing statement within 45 days of the exchange event. The market price signal (determined by the utility) minus the customer's rate schedule energy price is the customers nominated curtailment level.

\begin{tabular}{|c|l|}
\hline Notification Required & Minimum Hourly Credit Rate \\
\hline Option 1@, 2 hours & 7 cents per kWh \\
\hline Option 2@3 hours & 5 cents per kWh \\
\hline Option3@4 hours & 3.5 cents per kWh \\
\hline
\end{tabular}

*Market Price Signal -- is a price or prices quoted for an exchange amount by the utility for a specified duration.

**Hourly Credit Rate - market price signal minus the customer's rate schedule energy price = hourly credit rate (cents/kWh).

***Hourly Credit - exchange amount $(\mathrm{kWh}) \mathrm{x}$ hourly credit rate $=$ hourly credit.

The benefit to the customer is cash or a credit to their future bill. 
IV. A meter is required. The utility pays for and installs the interval meter. The customer is required to provide telephone line access to the meter if requested by the utility. The customer is also required to pay for costs associated with any other load monitoring and communications equipment necessary to participate in the program, including internet access, except if the customer has participated prior to October 1, 2001.

*Washington - 55 eligible customers. Best month, 1 participant, $3800 \mathrm{MWhs}$ saved. (information provided by Nick Garcia, WA)

*Utah -30 customers participated in the program with an approximate reduction of 25.5 thousand MWH (based on paid curtailment). (information provided by Jeff Burks, UT)

\section{PacifiCorp (20/20) (residential/commercial)}

\section{0/20 Customer Challenge Program Rider 2001 (Idaho, Oregon, *Utah, *Washington) Residential/Small Commercial}

I. Customers participating in this program are required to have had continuous service at the same location under their normal rate schedules since September 2000.

II. Number of participants is not available for all states.

III. For the months of July, August, and September, 2001, customers with an average daily $\mathrm{kWh}$ usage between $80-90 \%$ or less of the average daily $\mathrm{kWh}$ billed to the customer at the same location in the same months in 2000, will have their total bill reduced by $10 \%$ for the current month. The customer's summer bill is reduced by $20 \%$ if the month of June is included in the average daily $\mathrm{kWh}$ usage calculation as stated above.

The benefit to the customer is a reduction in their electric bill during high demand summer months.

IV. No special meters are required.

*Washington - (Schedule 16 or 17) Twenty-four percent $(23,000$ out of 93,000) of customers reduced use 10 percent. Sixteen percent $(15,000$ out of 93,000) of customers reduced use 20 percent. Best Month: 29,000 MWhs saved. (information provided by Nick Garcia, WA)

*Utah - (applies to customers taking service under schedules 1, 2, 3, 23, or 23b) On average 127,076 residential customers in Utah participated each month. The average participant saved $165 \mathrm{kWh}$ per month. The average credit per participant was $\$ 7.49$ per billing cycle or 4.539 cents per $\mathrm{kWh}$. Schedule 23 participants received, on average, a credit of $\$ 13.40$ per month and saved $269 \mathrm{kWh}$ or 4.981 cents per $\mathrm{kWh}$. The combined reduction in usage from the residential and small commercial classes resulted in an approximate net-on-peak savings of $36 \mathrm{MW}$ or about $98,000 \mathrm{MWh}$. The weighted average cost per kWh of net savings is 4.76 cents per kWh. (information provided by Jeff Burks, UT)

\section{Avista Corporation (commercial/industrial)}

\section{Energy Buy-Back Program}


Commercial/Industrial (Washington) (information provided by Nick Garcia, WA)

I. To be eligible for this program, customers had to have a demand greater than 3,000 kva. Customers commit to a minimum one-day curtailment of a minimum of one MWh.

II. 23 eligible customers. Best Month: 5 participants, 4271 MWhs saved.

III. Utility specified buy-back price.

IV. A meter is required.

\section{Avista Corporation (agricultural)}

Irrigation Curtailment Program (Washington)

Agricultural Schedules 31 and 32 (information provided by Nick Garcia, WA)

I. This program is offered to customers served under Schedules 31 and 32 the option to sell power back to the utility by reducing their historical energy use.

II. 254 eligible customers, 24 participated. Average monthly savings 1,000 MWhs.

III. Utility specified buy-back price.

IV. No meter is required.

\section{Avista Corporation (residential/commercial/industrial)}

Customer Curtailment Program (information provided by Nick Garcia, WA)

Commercial/Industrial Schedule 92 (Washington)

\section{Residential Schedule 70R (Washington)}

I. This program is for customers who have lived at the same address or have had the same place of business for the past twelve consecutive months and were not under the utility's irrigation or large customer buy-back programs. The program began May 15, 2001 and ended October 12, 2001.

II. 49 percent of customers $(93,000$ out of 188,000$)$ met the 5 percent threshold. Best Month: 66,000 MWhs saved.

III. Customers received a monetary credit on their monthly statement of 5 cents $/ \mathrm{kWh}$ for each $\mathrm{kWh}$ of reduced energy usage in excess of 5 percent as compared to the same billing month last year. The incentive energy amount is determined by subtracting the customer's energy usage for the current billing period from 95 percent of the customer's adjusted energy usage for the prior year. The incentive energy amount shall then be multiplied by 5 cents $/ \mathrm{kWh}$ to result in a bill credit that will be applied to the customer's current bill.

IV. A meter is required.

\section{Avista Corporation (residential/commercial/industrial)}

All Energy Buyback (information provided by Bill Eastlake, ID) Commercial/Industrial/Residential Schedule 92 (Idaho) 
I. This program is for customers who have lived at the same address or have had the same place of business for the past twelve consecutive months and were not under the utility's irrigation or large customer buy-back programs. The program began May 15, 2001 and ended October 12, 2001.

II. Number of participants is not available.

III. Customers received a monetary credit on their monthly statement of 5 cents $/ \mathrm{kWh}$ for each $\mathrm{kWh}$ of reduced energy usage in excess of 5 percent as compared to the same billing month last year. The incentive energy amount is determined by subtracting the customer's energy usage for the current billing period from 95 percent of the customer's adjusted energy usage for the prior year. The incentive energy amount shall then be multiplied by 5 cents/kWh to result in a bill credit that will be applied to the customer's current bill.

IV. A meter is required.

\section{Idaho Power (commercial/industrial/irrigation)}

\section{Energy Buy-Back Temporary Program (optional) Commercial/Industrial Schedule 22 (Idaho and Oregon)}

I. This is a voluntary load reduction program available to customers who are able to reduce their electric load by at least $1,000 \mathrm{~kW}$ at one metering point, during specific hours, and at a specific price determined by the utility. An exchange event can be for the same-day, a day-ahead, or two-days ahead. The minimum time for an event will be two consecutive hours. There may be more than one event in a day. The utility notifies the customer of an event, the hours that load reduction is needed, and the bid price for each hour of the event, via email in conjunction with an interactive Internet site. Pagers, telephones, or faxes are also acceptable if the customer does not respond by email/website notification.

Customers wanting to participate reply to the utility with the hours they choose to participate and what their committed load will be. The utility will notify the customer within four business days after the exchange event of the customer's base load, actual load, exchange load, and committed load output information.

II. Number of participants is not available.

III. The customer will receive a monetary credit on their account within 45 days of the end of an event. The credit is calculated in the table below.

\begin{tabular}{|c|c|c|c|c|}
\hline & First event & $\begin{array}{l}\text { Hourly exchange } \\
\text { load (85 percent - } \\
115 \text { percent) of } \\
\text { committed load }\end{array}$ & $\begin{array}{l}\text { Hourly exchange } \\
\text { load (less than } 85 \\
\text { percent of } \\
\text { committed load) }\end{array}$ & $\begin{array}{l}\text { Hourly exchange } \\
\text { load (greater than } \\
115 \text { percent of } \\
\text { committed load) }\end{array}$ \\
\hline $\begin{array}{l}\text { Exchange } \\
\text { credit }\end{array}$ & $\begin{array}{l}\text { bid price } \mathrm{x} \\
\text { exchange load* }\end{array}$ & $\begin{array}{l}\text { bid price } \mathrm{x} \\
\text { exchange load }\end{array}$ & $\begin{array}{l}\text { exchange load } \mathrm{x} \text { bid } \\
\text { price }-(\text { committed } \\
\text { load }- \text { exchange } \\
\text { load }) \mathrm{x} \text { bid price }\end{array}$ & $\begin{array}{l}\text { (committed load } x \\
115 \text { percent } x \text { bid } \\
\text { price })+((\text { exchange } \\
\text { load }-(\text { committed } \\
\text { load } x 115 \text { percent })) \\
x \quad 1 / 2 \text { bid price })\end{array}$ \\
\hline
\end{tabular}

*Exchange load - is the hourly difference between the base load and the actual load measured in $\mathrm{kW}$. 
The only penalty associated with the program is if the customer terminates participation prior to the end of the required one-year enrollment period. In that case, the customer must reimburse the utility for all setup costs associated with enrolling in the program.

IV. A meter is required. The utility provides and installs an interval meter at no charge to the customer. The customer is required to provide a dedicated phone line to the meter if one is not already in place. Service is required for one year or until March 14, 2002 -- when the program expires. The program may be extended in one-year intervals.

\section{Idaho Power (irrigation)(Oregon)}

\section{Irrigation Schedule 23}

I. This program is available to customers who voluntarily reduce energy consumption during the 2001 growing season (March 1, 2001 through November 30, 2001). Customers must remain connected for the full term of the program.

II. Number of participants is not available.

III. The price paid to the customer was 15 cents per $\mathrm{kWh} /$ month. This payment equaled 75 percent of the actual energy reduction times the purchase price. The remaining 25 percent was retained by the utility and was paid to the customer after confirmation that the customer provided the agreed upon energy reduction. The minimum energy reduction required of the customer was $100,000 \mathrm{kWh}$. It was measured by comparing a customer's base energy consumption amount (total of the average $\mathrm{kWh}$ consumption at each metered service point during the immediately preceding five years) with the amount of annual electric energy consumption that the customer actually consumes at the metered service point. The penalty for noncompliance was that the customer paid twice the purchase price for the amount of energy reduction, which was less than 95 percent of the offered energy amount.

The benefit to the irrigators was being paid per kWh not to use energy in high price periods.

IV. A meter is required.

\section{British Columbia Hydro \& Power Authority (CANADA) (commercial/industrial buy- back)}

\section{Price Dispatched Curtailment (PDC) Program}

Commercial/Industrial Schedule 1849 (information provided by Denise Mullen-Dalmer)

I. Participation in this program is available to transmission voltage customers and was designed to capture the opportunities that exist when market prices for electricity are high and the utility has spare export transmission capacity. Under such conditions, subscribers were to be given a minimum two hours' notice from the utility requesting that they consider curtailing a portion of their load in one or more "curtailment windows". Curtailment windows could be set by the utility between 6:00 a.m. and 10:00 p.m. each day. Any single window would be a minimum of one hour, and a 
maximum of four hours, although there could be more than one window per day. A customer that chose a given window had to curtail for the duration of that window.

The minimum curtailment of load for each event was 4MWh per hour for the duration of the curtailment window. Estimates of the market price for load to be sold within the customer's chosen window were available at that time, to help with the customer's decision.

II. The most recent evaluation report, for the six-month period ending September 30, 2001 stated that there were no curtailment events during the period. In the prior sixmonth period, 12 Transmission customers subscribed to the program and 11 PDC events were called. An average of $85 \mathrm{MW}$ was curtailed per event.

III. Within 48 hours of the event, the utility was obliged to tell the subscriber what the Market Price was during the curtailment. In determining the credit earned by the curtailing customer, B.C. Hydro multiplied the amount of curtailed load by the Market Price and subtracted the value of the energy at the customer's normal rate and level of consumption. The remaining value (difference) was divided equally between the utility and the curtailing customer. Any energy taken by the customer above the level it had agreed to curtail to would be charged at three times the market price.

IV. Participating customers required a personal computer, plus load monitoring equipment valued at about $\$ 3,000 \mathrm{Cdn}$. 


\section{Demand Bidding}

Demand bidding programs are for the customer to propose a bid to purchase energy instead of responding to a utility request for participating in bids at a pre-determined price. This is also a voluntary program.

\section{Southern California Edison (commercial/industrial)}

\section{Demand Bidding Program}

Commercial/Industrial (information taken from rate schedule)

I. This is a voluntary program where customers with a demand of $100 \mathrm{~kW}$ and above, log onto the utility website to place a curtailment bid for the following day (dayahead program). Bid commitments are submitted in four-hour blocks, and customers may choose from one of four price options determined by the California Independent Systems Operator and the California Department of Water Resources. The program began in the summer of 2001 and is scheduled to run through October 2002.

II. 96 customers are currently signed up for the program. As of February 2002, the program has never actually run. The California Department of Water Resources determines, based on the price of energy, when and at what price they need customers to drop load. Thus far, they haven't needed the load reduction that the program provides.

III. Customers submit bids. The amount of credit received is determined by applying the accepted bid price to the qualified $\mathrm{kWh}$ reduction (at least $10 \%$ of average annual demand in the previous 12 months, but not less than $100 \mathrm{~kW}$ ).

IV. A meter is required. The utility installs and provides meters at no cost to the customer. A customer must have Internet access and interval metering (usage is recorded in one hour intervals), and must participate for one year to quality for the credit. However, purchasing and installing interactive website software was the most expensive portion of the setup cost for SCE.

\section{Sempra San Diego Gas \& Electric (commercial/industrial) \\ Demand Bidding Program \\ Commercial/Industrial Schedule DBP (information taken from rate schedule)}

I. This is a voluntary program where, on a day-ahead basis, customers will bid the amount of electric load they can reduce and at a price at which they are willing to reduce their load based on market prices for the following day. Bids will be accepted for three four-hour time blocks: 8 am to noon, noon to $4 \mathrm{pm}$, and $4 \mathrm{pm}$ to $8 \mathrm{pm}$. The load reduction amount bid must be the same for every hour within the specific fourhour time block. Customers must reduce load by at least $10 \%$ or a minimum reduction of $100 \mathrm{~kW} /$ meter, whichever is greater, in comparison to their average use for the same hours during the 10 previous days.

II. 3 participants

III. This is a pay-for-performance program. Customers receive credits on their account based on the amount of load reduced during a specific four-hour time block, as detailed in an accepted bid. Credits are calculated per $\mathrm{kWh}$, based on the price bid by 
the participant. There are no financial penalties for failure to comply. However, incentives will not be provided for load reductions achieved which do not meet the minimum criteria, and which are not within at least $50 \%$ of the accepted bid amount. The benefit to the customer is a credit on their account, upgraded metering equipment, and a telephone communication link between the meter and an Internet service to help monitor their energy usage.

IV. A meter is required. The utility installs and provides a meter at no cost as well as the telephone link and Internet service.

\section{Pacific Gas \& Electric (commercial/industrial) Demand Bidding Program Commercial/Industrial Schedule DBP (information taken from rate schedule)}

I. This is a voluntary program where, on a day-ahead basis, customers will bid the amount of electric load they can reduce for a given bid price during specific time periods. Bids will be accepted for three four-hour time blocks: 8 am to noon, noon to $4 \mathrm{pm}$, and $4 \mathrm{pm}$ to $8 \mathrm{pm}$. The load reduction amount bid must be the same for every hour within the specific four-hour time block. There is no limit to the number of events. Customers must reduce load by at least $10 \%$ of their average annual demand, which shall not be less than 100 kilowatt $(\mathrm{kW})$ each hour during an event. Average annual demand is defined as the sum of the previous twelve 12 months' energy usage in kilowatt-hours $(\mathrm{kWh})$, divided by the number of hours per year.

II. Number of participants is not available.

III. The California ISO and the California Department of Water Resources will state which set of prices (Option 1 or Option 2 ) will be in effect during each event.

\begin{tabular}{|c|c|}
\hline Option 1 & Option $\mathbf{2}$ \\
Bid Prices (per kWh) & Bid Prices (per $\mathbf{k W h})$ \\
\hline 15 cents & 10 cents \\
\hline 35 cents & 30 cents \\
\hline 55 cents & 50 cents \\
\hline 75 cents & 70 cents \\
\hline
\end{tabular}

The customer chooses one of the four bid prices above and the CAISO/CDWR determines if it will be accepted on an event-by-event basis. The customer's bid consists of: the event time block chosen; a bid price selected by the customer; and the amount of $\mathrm{kW}$ per hour the customer commits to reduce during the event. The utility will pay the customer's hourly load reduction within 90 days after each event as an adjustment to their regular monthly bill. Credits are calculated per kWh, based on the price bid by the participant. Credits will only apply to the portion of energy reduction in any hour that falls within a plus or minus fifty percent $(+/-50 \%)$ bandwidth of the customer's bid. There are no financial penalties for failure to comply. However, incentives will not be provided for load reductions achieved which do not meet the minimum energy reduction threshold of 10 percent of the customer's Average Annual Demand, but not less than $100 \mathrm{~kW}$ criteria, and which are not within at least $50 \%$ of the accepted bid amount.

IV. A meter is required. The utility installs and provides a meter at no cost. The customer is responsible for installation and monthly fees associated with telephone equipment, a dedicated line required for the remote reading or monitoring of the 
interval meter, Internet service, and an alphanumeric pager capable of receiving a text message sent via the Internet. 


\section{Direct Load Control}

Direct Load Control programs target customers with equipment that can be turned off or cycled for relatively short periods of time.

\section{Sacramento Municipal Utility District (commercial/industrial)}

\section{Energy Direct Program}

Commercial/Industrial (information taken from rate schedule)

I. A voluntary program where customers sign up and agree to curtail energy use, by a certain $\mathrm{kW}$ during Stage 3 alerts. A key component of this program is that energy devices are pre-determined by the participant, but then are controlled, via remote, by SMUD.

II. There are currently 2 customers in this program.

III. Number of participants is not available.

IV. A meter is required. Meters that are installed are part of an upgrade plan the customer pays for. This allows the utility to monitor the customer's energy usage over the phone lines. 
Dispatchable Standby Generation

Standby generation allows customers' standby generator(s) to be operated in synchronization with the electrical distributor whereby the units can be monitored and dispatched by the control area operator.

\section{Portland General Electric (commercial/industrial)}

\section{Dispatchable Generation Program}

Commercial/Industrial (information taken from rate schedule)

I. Voluntary program for customers with standby generators already in place, or wishing to construct standby generators. The utility offers a variety of incentives and compensation for the right to use the customer's generator for up to 400 hours/year to meet peak power demands. The customer's generator will operate in parallel with the utility's power, but will always be available to back up the facility for which it is designed. Qualifying commercial and industrial customers (those with standby generators of 1 megawatt and up) are networked with the utility's communications and power control system. The standby units can be monitored and dispatched from the utility's control center.

II. There are currently 6 customers signed up, for a total of $8 \mathrm{MW}$ online. There are 12 facilities under construction and more in the works.

III. The customer is not compensated directly for any power going back into the grid from the generator. The generators themselves are not funded by the utility, but the utility will help fund the installation cost for participants. However, the benefit to the customer for participation in this program, the utility will upgrade switchgear and install control and communications hardware, assume all maintenance and operation costs (including fuel), provide additional sound attenuation, provide additional fuel storage, and test the system at least once a month under full load.

IV. The utility pays for all communication including meters, software, and telephone lines. 
Interruptible

Interruptible programs are available to customers willing to have their operations interrupted by a utility for a few hours or a shift.

\section{Southern California Edison (commercial/industrial)}

\section{Base Interruptible Program}

Commercial/Industrial (information taken from rate schedule)

I. This is a voluntary program where customers with at least $100 \mathrm{~kW}$ demand, who can reduce usage by $15 \%$ (minimum of $100 \mathrm{~kW}$ for each event) will receive a monthly monetary credit for reduced energy use based on the difference between their maximum demand and the minimum amount of electricity customers need for basic operation. The program is effective from May 14, 2001 to December 31, 2002. Penalties are $\$ 6.00$ per kWh of energy use above their minimum amount of electricity they need for basic operation. Events may happen any day of the year, but cannot exceed 4 hours, 10 events per month, or 120 hours/year.

II. Number of participants is not available.

III. Customers receive two forms of compensation as the benefit for participating in the program. 1) An electric rate reduction, based on the demand the customer places on the utility's system, time of day and season, and the amount of electricity designated as "interruptible." 2) A monetary credit based on the difference between each month's maximum demand and the customer's selected minimum amount of electricity they need for basic operation. (Maximum demand is the sum of the monthly kWhs consumed in the peak period divided by the number of hours in that period).

IV. A meter is required. The utility provides and installs the appropriate metering device at no cost to the customer. A customer must pay for a dedicated phone line to provide direct communications with the utility.

\section{Southern California Edison (commercial/industrial) \\ Interruptible Service Program \\ Commercial/Industrial Schedule I-6 (information taken from rate schedule)}

I. This is a voluntary program where customers with $500 \mathrm{~kW}$ and above and/or new and expanding load customers, will receive a monthly credit for reduced energy use based on the difference between their maximum demand and the minimum amount of electricity the customer needs for basic operation - not more than $50 \%$ of maximum demand. An event may occur any day of the year but is limited to 25 events per year, and will not exceed 6 hours per day, 4 events per calendar week, and no more than 40 hours per month or 150 hours per year. Penalties are $\$ 7.20$ - $\$ 9.30$ per kWh of energy use consumed during the interruption event. The program and rate have been extended to December 31, 2002.

II. Number of participants is not available.

III. Customers receive two forms of compensation. 1) An electric rate reduction, based on the demand the customer places on the utility's system, time of day and season, 
and the amount of electricity designated as "interruptible." 2) A credit based on the difference between each month's maximum demand and the customers selected minimum amount of electricity they need for basic operation. (Maximum demand is the sum of the monthly $\mathrm{kWh}$ consumed in the peak period divided by the number of hours in that period).

IV. A meter is required. The utility pays for the meter and its installation. The customer pays for the communication cable from the meter to the utility. The customer is responsible for a dedicated phone line as a direct communication link to the utility.

\section{Pacific Gas and Electric (commercial/industrial)}

\section{Base Interruptible Program}

Commercial/Industrial Schedule E-BIP ( information taken from rate schedule)

I. This program is available to customers that have at least an average monthly demand of $100 \mathrm{~kW}$. The customer will be required to reduce their load down to the minimum amount of electricity the customer needs for basic operation - no more than $85 \%$ of the customer's highest monthly maximum demand over the past 12 months -- within thirty minutes of notification via the Internet or a text messaging pager. Interruptions are limited to a maximum of one event per day and four hours per event, and will not exceed ten events during a calendar month. The program and rate is available through December 31, 2002.

II. Number of participants is not available.

III. The customer will receive a monetary credit reflected as an adjustment on their regular monthly bill within 90 days after each curtailment event. Such credits are determined by the season. In summer, payments are based on the difference between the customer's average monthly on-peak period demand and its designated minimum operational needs. In winter it is based on the customer's average monthly partialpeak period demand and its designated minimum operational needs. Customers are penalized $\$ 6.00 / \mathrm{kWh}$ for energy usage over their minimum operational needs limit during a curtailment.

IV. A meter is required. When needed, the utility will provide and install metering equipment at no cost to the customer. The customer is responsible for the installation and monthly fees associated with telephone equipment and a dedicated line required for the remote reading or monitoring of the meter. Equipment must be in operation for at least 10 days prior to beginning of the program and a one-year participation period is required.

Xcel Energy (commercial/industrial)

Primary Interruptible Service

Commercial/Industrial Schedule PI ( information taken from rate schedule) 
I. This schedule is for customers who have demands of $500 \mathrm{~kW}$ or greater at least once during every consecutive twelve month period. Service shall be for a minimum period of twenty-four consecutive months. Customers will have interruption options as detailed below.

II. 64 participants 
III. Charges are as follows:

\begin{tabular}{|c|c|c|c|c|}
\hline $\begin{array}{l}\text { Service \& Facility } \\
\text { charge/month }\end{array}$ & & & & $\$ 210.00$ \\
\hline $\begin{array}{l}\text { Interruptible Demand } \\
\text { charge } / \mathrm{kW}\end{array}$ & $\frac{\text { Interruption }}{\text { Days/year }}$ & $\frac{\text { Limits }}{\text { Hours/Day }}$ & $\begin{array}{l}\text { Advanced } \\
\text { Notice }\end{array}$ & \\
\hline & Unlimited & Unlimited & No Notice & $\$ 8.92$ \\
\hline & Unlimited & Unlimited & 30 minutes & $\$ 9.58$ \\
\hline & 20 days & 12 hours & No-Notice & $\$ 10.28$ \\
\hline & 20 days & 12 hours & 30 minutes & $\$ 11.19$ \\
\hline & 10 days & 12 hours & No-Notice & $\$ 11.09$ \\
\hline & 10 days & 12 hours & 30 minutes & $\$ 12.07$ \\
\hline $\begin{array}{l}\text { Interruptible Energy } \\
\text { charge - all kWh }\end{array}$ & & & & \$ 1.61 \\
\hline $\begin{array}{l}\text { Interrupted capacity } \\
\text { credit -- all kWh of } \\
\text { interrupted capacity } \\
\text { demand }\end{array}$ & & & & $\$(1.61)$ \\
\hline
\end{tabular}

A penalty charge for failure to interrupt is calculated by multiplying the total amount of interruptible energy taken during the event period by the penalty charge per kilowatt hour. The penalty charge is $\$ 4.00 / \mathrm{kWh}$ for customers with an unlimited interruption option. The penalty charge is $\$ 2.00 / \mathrm{kWh}$ for customers with a 20 interruption-days/year option, and a $\$ 1.00 / \mathrm{kWh}$ penalty charge for customers who take the 10 interruption-days/year option. Some exceptions apply.

IV. A meter is required. The utility installs a metering device, but the customer pays monthly use charges.

\section{$\underline{\text { Xcel Energy Interruptible variations }}$}

Secondary Interruptible

Secondary Seasonal Interruptible

Primary Seasonal Interruptible

Transmission Interruptible

Transmission Seasonal Interruptible service

Agricultural Irrigation Interruptible service

\section{PacifiCorp - Utah Power \& Light (State of Idaho) (commercial/industrial) Interruptible Power Service \\ Commercial/Industrial Schedule 24}

I. For customers with power loads of $1000 \mathrm{~kW}$ or greater who contract with the utility for an annual guaranteed availability of energy supply of $60,70,80$, or 90 percent. The total annual interruption in kWh during any contract year shall not exceed the difference between the contract demand in $\mathrm{kW}$ multiplied by 8760 hours and the guaranteed availability in $\mathrm{kWh}$ contracted for by the customer.

II. Number of participants is not available. 
III.

\begin{tabular}{|l|l|l|l|l|l|l|l|l|}
\hline Delivery voltage & \multicolumn{4}{|c|}{$\mathbf{4 6} \mathbf{~ k V}$ or higher } & \multicolumn{3}{|c|}{$\mathbf{2 . 3} \mathbf{~ k V}$ to less than $\mathbf{4 6} \mathbf{~ k V}$} \\
\hline $\begin{array}{l}\text { Interruption } \\
\text { Availability }\end{array}$ & $\mathbf{6 0 \%}$ & $\mathbf{7 0 \%}$ & $\mathbf{8 0 \%}$ & $\mathbf{9 0 \%}$ & $\mathbf{6 0 \%}$ & $\mathbf{7 0 \%}$ & $\mathbf{8 0 \%}$ & $\mathbf{9 0 \%}$ \\
\hline $\begin{array}{l}\text { Power rate charge: } \\
\text { all kW/month }\end{array}$ & $\$ 4.78$ & $\$ 5.68$ & $\$ 6.60$ & $\$ 6.94$ & $\$ 7.06$ & $\$ 7.74$ & $\$ 8.42$ & $\$ 8.69$ \\
\hline $\begin{array}{l}\text { Energy rate charge: } \\
\text { all kWh/month }\end{array}$ & $\begin{array}{l}3.7163 \\
\text { cents }\end{array}$ & $\begin{array}{l}3.7163 \\
\text { cents }\end{array}$ & $\begin{array}{l}3.7163 \\
\text { cents }\end{array}$ & $\begin{array}{l}3.7163 \\
\text { cents }\end{array}$ & $\begin{array}{l}4.0536 \\
\text { cents }\end{array}$ & $\begin{array}{l}4.0536 \\
\text { cents }\end{array}$ & $\begin{array}{l}4.0536 \\
\text { cents }\end{array}$ & $\begin{array}{l}4.0536 \\
\text { cents }\end{array}$ \\
\hline $\begin{array}{l}\text { Customer } \\
\text { charge/month }\end{array}$ & $\$ 326.34$ & -- & -- & -- & $\$ 266.11$ & -- & -- & -- \\
\hline
\end{tabular}

The benefit to the customer is choosing the amount of power to be interrupted by the utility and at what price.

IV. A meter is required.

\section{PacifiCorp (State of Utah) (industrial)}

\section{Bilateral Contract Program}

Industrial (information provided by Jeff Burks, UT)

I. This contract is set up as a spinning reserve contract between the customer and

PacifiCorp. For a stated power price, the customer agrees to reduce load within 10 minutes of notification. The load reduction and number of hours of interruption is specified in the contract.

II. 1 participant, about $70 \mathrm{MW}$.

III. The benefit to the customer is reduced firm energy price. The benefit to other customers is relatively low cost peak power.

IV. Specific equipment required.

Salt River Project Interruptible Program (commercial)

Service Riders ( information taken from rate schedules)

\section{Use Fee Interruptible Rider}

Supplemental to General Service Price Plans E-32 and E-36, Pumping Price Plans E-47 and E-48, Large General Service Price Plans E-61, E-63, and E-65

This service is for customers who have a minimum annual load of $100 \mathrm{~kW}$.

Instantaneously Interruptible Rider

Supplemental to Large General Service Price Plan E-65

This service is for customers who have at least $2,500 \mathrm{~kW}$ of interruptible load.

Interruptible Rider with 10 minutes notice

Supplemental to Large General Service Price Plans E-61, E-63, and E-65

This service is for customers who have at least $2,500 \mathrm{~kW}$ of interruptible load.

Texas-New Mexico Power Company (commercial/industrial)

Interruptible Power Large General Service 
Commercial/Industrial Rate No. 10 (information taken from rate schedule)

I. Customers using this service have a minimum actual demand of $500 \mathrm{~kW}$. The contract with the customer shall be for no less than 24 months.

II. Number of customers is not available.

III. The monthly energy charge is $\$ 3.78$.

IV. A meter is required. 


\section{$\underline{\text { Texas-New Mexico Commercial/Industrial variations }}$}

Interruptible Industrial Power Service

Interruptible Irrigation Service

\section{Sempra San Diego Gas \& Electric (commercial/industrial)}

\section{Base Interruptible Program}

Commercial/Industrial Schedule BIP (information taken from rate schedule)

I. This service is applicable to all time-of-use metered customers who can commit to curtail at least 15 percent of load, with a minimum load drop of $100 \mathrm{~kW}$, and within 30 minutes of being notified of an event. Interruptions shall not exceed 4 hours for any calendar day, nor 10 periods per month, nor 120 hours per calendar year.

II. $\quad 0$ participants

III. Customers receive a monthly credit of $\$ 7.00$ per $\mathrm{kW}$ of curtailable load. This credit is applied to their monthly bill. Customers are penalized $\$ 6.00 / \mathrm{kWh}$ for excess energy usage. This excess usage is the amount used during any 15-minute interval when a customer is supposed to be curtailing.

IV. A meter is required. As needed, the utility will provide and install metering equipment at no cost to the customer. The customer is responsible for an Internet connection and email address or text capable pager to receive communications from the utility via the Internet. The customer is also responsible for the installation and monthly fees associated with telephone equipment and a dedicated line required for the remote reading or monitoring of the meter. Equipment must be in operation for at least 10 days prior to beginning the program and a one-year participation period is required.

\section{California Independent Systems Operator (CAISO) (commercial)}

Demand Relief Program (2001) (information taken from CAISO account manager)

This program operated in 2001 from June to September. The program was applied to customers with single or aggregated loads of greater than or equal to $1 \mathrm{MW}$. The length of interruption was 4 hours ( 2 equal blocks) between 11 am and 7 pm with a maximum monthly operation of 24 hours after which curtailment is optional. Customers received monetary payments for participating. No other information is available.

\section{Tucson Electric (agricultural)}

\section{Interruptible}

Agricultural Pumping Schedule No. 31 (information taken from rate schedule)

I. Applicable to separately metered interruptible agricultural water pumping service for irrigation purposes of the customer only. Summer billing months are May through October. Winter billing months are November through April.

II. Number of customers is not available. 
III. *Additional adjustments on this schedule apply, but have not been included.

\begin{tabular}{|l|l|}
\hline \multicolumn{2}{|l|}{ Rates* } \\
\hline Distribution - Primary Metering & \\
\hline Summer $\mathrm{kWh}$ & $\$ 0.005723$ per $\mathrm{kWh}$ \\
\hline Winter $\mathrm{kWh}$ & $\$ 0.005529$ per $\mathrm{kWh}$ \\
\hline Distribution - Secondary Metering & \\
\hline Summer $\mathrm{kWh}$ & $\$ 0.003186$ per $\mathrm{kWh}$ \\
\hline Winter $\mathrm{kWh}$ & $\$ 0.003106$ per $\mathrm{kWh}$ \\
\hline
\end{tabular}

The customer guarantees that load shall not be less than $\$ 30.00$ per hp connected per contract year (April 1 to March 31 of the following year) and no less than $\$ 1,800.00$ per contract year. Minimum payments shall be made at the rate of $\$ 2.50$ per hp of motors connected, but not less than $\$ 150.00$ shall be made monthly. If total payments exceed the above rates, then the customer shall be credited the difference between the amount actually paid during the contract year and the amount which would have been paid had the monthly minimum charge not been applied.

IV. A meter is required. Meter shall be purchased by customer at their expense. Customer also pays for installation and maintenance.

\begin{tabular}{|c|l|}
\hline \multicolumn{2}{|c|}{ Meter Services* } \\
\hline Installation & \\
\hline Summer & $\$ 0.000199$ per $k W h$ \\
\hline Winter & $\$ 0.000194$ per $k W h$ \\
\hline Maintenance & \\
\hline Summer & $\$ 0.000040$ per $k W h$ \\
\hline Winter & $\$ 0.000039$ per $k W h$ \\
\hline Equipment & \\
\hline Summer & $\$ 0.000159$ per $k W h$ \\
\hline Winter & $\$ 0.000155$ per $k W h$ \\
\hline
\end{tabular}

*Additional adjustments for seasonal meter reading services and billing and collection have not been included.

\section{Sierra Pacific Power Company (commercial)}

\section{Optional Interruptible}

Large General Service Schedule No. INT (information taken from rate schedule)

I. Service under this schedule is available to all or a portion of any service where the total demand exceeds one thousand $(1,000) \mathrm{kW}$ and where the demand designated as interruptible exceeds one thousand $(1,000) \mathrm{kW}$. Service is restricted to a cumulative interruptible load not to exceed 30 megawatts and is only available to customers who can reduce load when requested from the utility within ten minutes of notice, whose demand reduction is consistent with the utility's approved resource plan, and who has operating standby generation. The length of interruptions shall not exceed 100 cumulative hours in any calendar year.

II. Number of customers is not available.

III. Monthly service rates shall be reduced by the following credits.

\begin{tabular}{|c|l|}
\hline Demand Charge Credit & Rate \\
\hline For each kW of Contract Interruptible & $\$ 1.17$ \\
\hline
\end{tabular}




\begin{tabular}{|c|l|}
\hline Load, per kW per month & \\
\hline Energy Cost Credit for Self-Generation & $\begin{array}{l}\text { Contract amount shall not exceed 4 cents per kilowatt } \\
\text { hour }\end{array}$ \\
\hline *see explanation below
\end{tabular}

*The credit will be calculated as the difference between the customer's applicable electric service energy charge and the customer's estimated cost to operate his own generation, multiplied by the number of kilowatt hours the customer operates during the period or periods of requested interruption or parallel operation.

An additional energy cost credit will compensate the customer for providing the energy in excess of the customer's load during the period or periods of requested parallel operation. This additional energy cost credit will be calculated using the energy rates for purchases under utility Schedule No. CSPP multiplied by the kilowatt hours the customer's generation delivers to the utility during the requested parallel generation period.

IV. A meter is required.

\section{Sierra Pacific Power (agricultural)}

\section{Interruptible}

Irrigation Schedule No. IS-2 (information taken from rate schedule)

I. This schedule is applicable for the billing period March 1 through November 30. Service shall be supplied at one standard secondary voltage. Customers must participate for a minimum of one year.

II. Number of customers is not available.

III. MW used is a total of 4 .

\begin{tabular}{|l|l|}
\hline Monthly Charges & Rates \\
\hline Energy charge - all $\mathbf{k W h}$ per kWh & \\
\hline Base Tariff General Rate & 6.43 cents \\
\hline Base Tariff Energy Rate & 3.808 cents \\
\hline Total Energy Charge & $\mathbf{4 . 4 5 1}$ cents \\
\hline Late Charge & 1 percent of any amount in arrears from previous bills \\
\hline Tax Adjustment Charge & 2 percent of total bill \\
\hline Universal Energy Charge (UEC) & \\
\hline All kWh per kWh & $\$ 0.00039$ \\
\hline
\end{tabular}

IV. A meter is required.

\section{Nevada Power Company (agricultural)}

Interruptible (information provided by Carl Linvill)

The Colorado River Commission has an interruptible agreement with this utility. No other information is available. 


\section{British Columbia Hydro \& Power Authority (commercial/industrial)}

\section{Modified Demand Transmission Service}

Commercial/Industrial Schedule 1852 (information provided by Denise Mullen-Dalmer)

I. This service is available to all transmission voltage customers on standard billing (non-RTP). The program exchanges demand flexibility in LLH (i.e. no incremental demand charges above historic levels) for the right by the utility to require the customer to reduce demand at times when it is beneficial to the utility. It does so by calculating demand charges based on the higher of the HLH consumption or historic LLH consumption. The customer can, under some conditions, reject a call for demand reduction, including the option of buying-out a demand reduction request. The curtailments made by the customer are capacity reductions as opposed to energy reductions.

II. Only one customer has adopted this schedule. During its first year of operation (ending November 30, $2001 \mathrm{BC}$ Hydro initiated six demand reduction events and the customer responded in all cases. A total of $600 \mathrm{MWh}$ was curtailed by the customer during the year and the value to the utility was about $\$ 36,000 \mathrm{Cdn}$.)

III. If the customer opts to buy-out of a demand reduction event, the charge is $\$ 0.125 / \mathrm{kWh}$ times the maximum duration of the event times the minimum reductions. A customer that agrees to a demand reduction but then fails to reduce demand is required to pay the utility for each hour of the demand reduction period and each $\mathrm{kWh}$, an amount equal to $150 \%$ of the Mid-C price for that day.

IV. Demand meters are required. 


\section{Black Out Protection}

This is a load reduction program that exempts customers from rotating outages in exchange for partial load reduction of the entire circuit during every rotating outage.

\section{Southern California Edison (commercial/industrial)}

\section{Optional Binding Mandatory Curtailment Program}

Commercial/Industrial (information taken from rate schedule)

I. For very large customers who have the ability to reduce up to 15 percent of power from a single circuit or a participating circuit in 5 percent increments during every rotating outage when directed to do so by the utility.

II. 14 participants

III. No financial incentives. The benefit to the customer is the exemption from rotating outages.

IV. A meter is required. Customers in this program have existing metering equipment.

\section{Pacific Gas and Electric (commercial/industrial)}

\section{Optional Binding Mandatory Curtailment Program}

Commercial/Industrial Schedule OBMC (information taken from rate schedule)

I. This program is for customers who reduce up to 15 percent of their circuit load below the prior year's average monthly peak circuit demand, adjusted for any major changes in loads on the circuit. Load reductions are required in increments from 5 percent up to 15 percent of the circuit baseline load, and must correspond to California Independent Systems Operators requirements. The circuit baseline is determined by the average hourly electric usage on the circuit during the previous 10 similar days, excluding days a curtailment occurred. There is no limit on the frequency or duration of plan curtailments.

II. Number of participants is not available.

III. No financial incentives. The benefit to the customer is the exemption from rotating outages.

IV. Customers on a single circuit require a standard interval meter. Customers on a multiple customer circuit require substation level metering. Customers pay for metering equipment and installation.

\section{Sempra San Diego Gas \& Electric (commercial/industrial)}

\section{Optional Binding Mandatory Curtailment Program}

Commercial/Industrial Schedule OBMC (information taken from rate schedule)

I. This program is voluntary for customers who can reduce up to 15 percent of the total electric load on their circuit or shared circuits compared to the same month last year, or by $10 \%$ of the average usage for the immediate past ten similar days prior to the day a rolling blackout occurs. Customers must have a text capable pager and an Internet-based communications system to receive notifications and will have 15 minutes prior notice to reduce their load. 
II. 1 participant

III. No financial incentives. The benefit to the customer is the exemption from rotating outages. The penalty for non-compliance is $\$ 6 / \mathrm{kWh}$ for every hour of curtailment that load reduction does not occur.

IV. A meter is required. If the meter is not compatible with the utility system, the customer is required to pay for the installation of a new meter as well as the costs of appropriate telephone equipment and service to send data to the utility via telephone.

\section{California Independent Systems Operator (CAISO) (commercial)}

Voluntary Load Curtailment Program (information taken from account manager) This program is operated throughout the year after the Independent System Operator has declared a Stage 1 emergency. Curtailment requests are issued by the Independent System Operator to a pre-defined list of customers via e-mail. No compensation is made for curtailment. No other information is available.

\section{PacifiCorp (commercial/industrial)}

\section{Large Customer Curtailment Option}

Commercial/Industrial Schedule 73 (Oregon) (information provided by Jack Breen, OR PUC)

I. This is an optional program for customers with a monthly demand exceeding 4,000 $\mathrm{kW}$ at least once during the last 12-month period, and who are willing to curtail load up to a maximum of $15 \%$ in exchange for being excluded from scheduled rotating outages. The baseline for determining the customer's required load reduction is their average electricity usage, for each hour, for approximately 14 typical days during the period leading up to the event. Load reductions must begin within 30 minutes after the customer receives notification from the utility as to the estimated start and end times of the event. Service under this schedule is required for one year.

II. Number of participants is not available.

III. No compensation is made for curtailment. The benefit to the customer is the exclusion from rotating outages. Monetary penalties for failure to curtail to or beyond the required percentage load reduction within the specified amount of time, or who fail to maintain the load reduction for the entire duration of the event, will be penalized $\$ 10,000$ and may be removed from the program.

IV. A meter is required. Customers already have interval meters. Utility uses remote meter reading.

\section{Silicon Valley Power (commercial/industrial) \\ Mandatory Curtailment Program \\ Commercial/Industrial}

Agreement with customers per Ken Corum - Northwest Power Planning Council 
No other information is available. 


\section{Event Driven Demand Reduction}

Steps taken to reduce power demand at peak load times or to shift some of it to off-peak times. Utility installed and controlled equipment.

\section{Southern California Edison (commercial)}

Smart Thermostat Program (information taken from rate schedule)

I. This program is a six-month pilot (May 1, 2002 - October 31, 2002) for small business and/or nonprofit customers who have an average monthly billing demand of $200 \mathrm{~kW}$. A thermostat is connected to the utility via the Internet, which monitors and alters the customer's thermostat based on need during summer weekdays between noon and $6 \mathrm{pm}$ for up to a four-hour period.

II. The program begins this year with 700 thermostats - there can be more than 1 in each business. The plan calls for a total of 5,000.

III. The customer is eligible for a maximum annual cash incentive of up to $\$ 300$ for participating in the summer program. Incentives will be paid on an annual basis after the conclusion of the program. Incentive payments are reduced by $\$ 5.00$ for each override the customer initiates.

The benefit to the customer is a cash incentive for participating.

IV. Customers must have at least one air conditioning system between 5 and 20 tons nominal cooling rating with a single zone thermostat for each unit (more than one system may be included in the program). If a thermostat is not already available, the utility will pay for and install one valued at over $\$ 300$.

\section{Southern California Edison (residential)}

\section{Base Air Conditioner Cycling Program}

Residential Schedule D-APS (information taken from rate schedule)

I. The utility remotely activates an air conditioner cycling device by a radio signal and temporarily turns off, or cycles, the air conditioning unit. Interruptions are limited to 6 hours per event, 15 events per summer season (June-October). Multiple cycling occurrences can happen within one day. There are three different cycling options in each program: a) continuous - 100 percent - cycling; b) 20 minutes out of every 30 minutes - 67 percent; and c) 15 minutes out of every 30 minutes -50 percent. Air conditioner cycling occurs when a) electricity reserves drop below 5 percent; b) an emergency situation arises; and c) when testing the control device.

II.

\begin{tabular}{|l|l|l|l|}
\hline & Cycling & Participants & MW \\
\hline Continuous & 100 percent & 102,150 & 203.52 \\
\hline $\begin{array}{l}\text { 20 minutes out } \\
\text { of 30 minutes }\end{array}$ & 67 percent & 3,631 & 2.16 \\
\hline $\begin{array}{l}\text { 15 minutes out } \\
\text { of 30 minutes }\end{array}$ & 50 percent & 742 & .28 \\
\hline
\end{tabular}

III. Residential customers get the following monetary credits on their monthly summer bills: 


\begin{tabular}{|l|l|l|}
\hline & Cycling & Credits on summer bill /ton/day \\
\hline Continuous & 100 percent & 18 cents \\
\hline $\begin{array}{l}\mathbf{2 0} \text { minutes out } \\
\text { of } \mathbf{3 0} \text { minutes }\end{array}$ & 67 percent & 10 cents \\
\hline $\begin{array}{l}\mathbf{1 5} \text { minutes out } \\
\text { of } \mathbf{3 0} \text { minutes }\end{array}$ & 50 percent & 5 cents \\
\hline
\end{tabular}

Credits are based on the size of the air conditioning unit and the program in which the customer participates.

The benefit is a monetary credit on the customer's summery utility bill.

IV. Air conditioner cycling devices are provided and installed by the utility at no charge. Participation is required for one year by the customer from the date program service begins.

\section{Southern California Edison (residential) \\ Enhanced Air Conditioner Cycling Program \\ Residential Schedule D-APS-E (information taken from rate schedule)}

I. The utility remotely activates the air conditioner cycling device by a radio signal and temporarily turns off, or cycles, the air conditioning unit. Interruptions are unlimited occurrences with up to a maximum of 6 hours per event during the summer season (June-October). There are three different cycling options in each program:

a) continuous -100 percent - cycling; b) 20 min out of every 30 min - 67 percent; and

c) 15 min out of every 30 min -50 percent. Air conditioning cycling occurs when: electricity reserves drop below 5 percent; b) an emergency situation arises; and d) when testing the control device.

II. Continuous or 100 percent cycling has 3,655 participants for a total of $7.46 \mathrm{MW}$. No data is available for cycling options at 67 percent $\& 50$ percent due to a lack of bandwidth.

III. Residential customers get double monetary credits on their summer bills as follows:

\begin{tabular}{|l|l|l|}
\hline & Cycling & Credits on summer bill /ton/day \\
\hline Continuous & 100 percent & 36 cents \\
\hline $\begin{array}{l}\text { 20 minutes out } \\
\text { of } 30 \text { minutes }\end{array}$ & 67 percent & 20 cents \\
\hline $\begin{array}{l}\mathbf{1 5} \text { minutes out } \\
\text { of } \mathbf{3 0} \text { minutes }\end{array}$ & 50 percent & 10 cents \\
\hline
\end{tabular}

Credit is based on the size of the air conditioning unit and the program in which a customer participates.

The benefit is a double monetary credit on the customer's summer energy bills.

IV. A cycling device is provided and installed by the utility at no charge. One year of participation is required from the date program service begins.

\section{Southern California Edison (commercial)}

\section{Base Air Conditioner Cycling Program}

Commercial/Industrial Schedule GS-APS (information taken from rate schedule)

I. The utility remotely activates the air conditioning unit cycling device by a radio signal and temporarily shuts off, or cycles, the air conditioning unit. Interruptions are limited to 6 hours per event and a maximum 15 events per summer season (JuneOctober). Multiple cycling occurrences can occur within one day. There are four 
different cycling options in each program: a) continuous - 100 percent - cycling; b) 15 minutes out of every 30 minutes - 50 percent; c) 12 minutes out of every 30 minutes - 40percent; and d) 9 minutes out of every 30 minutes -30 percent. 
II.

\begin{tabular}{|l|l|l|l|}
\hline & Cycling & Participants & MW \\
\hline Continuous & 100 percent & 1843 & 32.5 \\
\hline $\begin{array}{l}\text { 15 minutes out } \\
\text { of 30 minutes }\end{array}$ & 50 percent & 462 & 4.52 \\
\hline $\begin{array}{l}\text { 12 minutes out } \\
\text { of 30 minutes }\end{array}$ & 40 percent & 48 & .36 \\
\hline $\begin{array}{l}\text { 9 minutes out } \\
\text { of 30 minutes }\end{array}$ & 30 percent & 71 & .47 \\
\hline
\end{tabular}

III. Customers get monetary credits on their summer bills according to different schedules. Credit is based on the size of the air conditioning unit and the program in which you participate.

\begin{tabular}{|l|l|l|}
\hline Schedule 1 & Cycling & Credits on summer bill /ton/day \\
\hline Continuous & 100 percent & 20 cents \\
\hline $\begin{array}{l}\mathbf{1 5} \text { minutes out } \\
\text { of } \mathbf{3 0} \text { minutes }\end{array}$ & 50 percent & 7 cents \\
\hline $\begin{array}{l}\mathbf{1 2} \text { minutes out } \\
\text { of } \mathbf{3 0} \text { minutes }\end{array}$ & 40 percent & 4.2 cents \\
\hline $\begin{array}{l}\mathbf{9} \text { minutes out } \\
\text { of } \mathbf{3 0} \text { minutes }\end{array}$ & 30 percent & 1.4 cents \\
\hline
\end{tabular}

\begin{tabular}{|l|l|l|}
\hline Schedule 2 & Cycling & Credits on summer bill /ton/month \\
\hline Continuous & $100 \%$ & $\$ 6.00$ \\
\hline $\begin{array}{l}\text { 15 minutes out } \\
\text { of 30 minutes }\end{array}$ & $50 \%$ & $\$ 2.10$ \\
\hline $\begin{array}{l}\text { 12 minutes out } \\
\text { of 30 minutes }\end{array}$ & $40 \%$ & $\$ 1.25$ \\
\hline $\begin{array}{l}\text { 9 minutes out } \\
\text { of 30 minutes }\end{array}$ & $30 \%$ & 42 cents \\
\hline
\end{tabular}

The benefit is a monetary credit on the customer's summer energy bills.

IV. A cycling device is provided and installed by the utility at no charge. One year of participation is required from the date program service begins.

\section{Southern California Edison (commercial/industrial)}

\section{Enhanced Air Conditioner Cycling Program}

Commercial/Industrial Schedule GS-APS-E (information taken from rate schedule)

I. The utility remotely activates the air conditioning unit cycling device by a radio signal and temporarily shuts off, or cycles, the air conditioning unit. Interruptions are unlimited occurrences with up to a maximum of 6 hours per event during the summer season (June-October). Multiple cycling occurrences can occur within one day. There are four different cycling options in each program: a) continuous - 100 percent - cycling; b) 15 minutes out of every 30 minutes - 50 percent; c) 12 minutes out of every 30 minutes - 40 percent; and d) 9 minutes out of every 30 minutes -30 percent.

II. The number of participants at 100 percent cycling is 60 for a total of $1.2 \mathrm{MW}$. No data is available for the number of participants at 50 percent, 40 percent, and 30 percent cycling due to a lack of bandwidth. 
III. Customers get double monetary credits on their summer bills according to different schedules. Credit is based on the size of the air conditioning unit and the program in which a customer participates.

\begin{tabular}{|l|l|l|}
\hline Schedule 1 & Cycling & Credits on summer bill /ton/day \\
\hline Continuous & 100 percent & 40 cents \\
\hline $\begin{array}{l}\mathbf{1 5} \text { minutes out } \\
\text { of } \mathbf{3 0} \text { minutes }\end{array}$ & 50 percent & 14 cents \\
\hline $\begin{array}{l}\mathbf{1 2} \text { minutes out } \\
\text { of } \mathbf{3 0} \text { minutes }\end{array}$ & 40 percent & 8.4 cents \\
\hline $\begin{array}{l}\mathbf{9} \text { minutes out } \\
\text { of } \mathbf{3 0} \text { minutes }\end{array}$ & 30 percent & 2.8 cents \\
\hline
\end{tabular}

\begin{tabular}{|l|l|l|}
\hline Schedule 2 & Cycling & Credits on summer bill /ton/month \\
\hline Continuous & 100 percent & $\$ 12.00$ \\
\hline $\begin{array}{l}\text { 15 minutes out } \\
\text { of 30 minutes }\end{array}$ & 50 percent & $\$ 4.20$ \\
\hline $\begin{array}{l}\text { 12 minutes out } \\
\text { of 30 minutes }\end{array}$ & 40 percent & $\$ 2.50$ \\
\hline $\begin{array}{l}\text { 9 minutes out } \\
\text { of } 30 \text { minutes }\end{array}$ & 30 percent & 84 cents \\
\hline
\end{tabular}

The benefit to the customer is a double monetary credit on the customer's summer energy bill.

IV. A cycling device is provided and installed by the utility at no charge. One year of participation is required from the date program service begins.

\section{Xcel Energy (residential)}

\section{Saver's Switch}

Residential Program (information taken from mailer)

I. This service is for residential customers with central air conditioning only. The utility remotely activates the air conditioning unit via a small device that is placed on the unit's outside condenser. The utility then cycles the unit's condenser on and off at 15 minute intervals during the late afternoon and early evening from June through August. The number of activations will be about $10-15$ days each summer when energy demand is highest. Minimum participation requirement is one year and customers must stay in the program throughout the summer.

II. New program beginning June 2002.

III. The customer receives the benefit of a $\$ 25$ credit on their October 2002 bill.

IV. A cycling device is provided and installed by the utility at no charge. 
Predetermined Demand Reduction

Voluntary financial incentive programs where customers are encouraged to reduce demand during predetermined peak demand periods.

\section{Platte River Power Authority (commercial/industrial)}

\section{Electric Efficiency Pilot Program}

Commercial/Industrial (information taken from program brochure)

I. Customers must use energy efficiency measures or load shifting measures to reduce summer peak electric demand ( 3 pm -7 pm Monday-Friday, June through August). Facilities must achieve $25 \mathrm{~kW}$ of demand reduction for 10 continuous years. The goal is savings for the long haul. Eligibility for this program is based on the equipment installed in either retrofitted facilities or to new construction applications. This program does not apply to previous installations.

II. Number of participants is not available. This is a first year pilot program.

III. Each customer receives financial incentives - check by installment - of $\$ 350$ per $\mathrm{kW}$ of summer demand savings. The maximum possible is $\$ 70,000$ for a project saving $200 \mathrm{~kW}$ or more.

The benefit to the customer is lowering the customer's energy costs with a resulting savings over a ten-year period. Half of estimated savings -- half after measurement.

IV. No equipment is specified. Monitoring is via on-site verification.

\section{Idaho Power (commercial/industrial)}

\section{*Astaris - Commercial/Industrial}

I. This program was implemented through an amendment to an existing flat rate take or pay contract with Astaris for 120MW. In the agreement, Astaris will not use more than 70MW of energy, allowing 50MW to be sold back to Idaho Power. The contract period is from April 1, 2001 - March 31, 2003.

II. 1 participant

III. The total buyback over two years is $876,000 \mathrm{MWh}$. That is $\$ 140$ million or 15.9 cents per kWh.

The benefit to the customer is getting paid to sell unused power back to Idaho Power at market rates minus a 14.5 percent discount.

IV. No meter is required.

*Note: The remainder of this contract is being terminated through a negotiated settlement whose terms are not final as of this date.

\section{Idaho Power (irrigation) (Idaho)}

\section{Irrigation Contract}

I. This 2001 program was designed to encourage irrigators to shift their irrigation usage pattern to a lower demand time period.

II. $\quad 446$ participants 
III. Irrigators were paid not to use energy during high price time periods. Potential savings for the program was 499,000 MWh. Total buyback for 2001 was equal to 15 cents per kWh. Load reduction was calculated based on historic electricity usage. The benefit to the irrigators was being paid per kWh not to use energy in high price periods from April - November 2001.

IV. No meter was required.

\section{British Columbia Hydro \& Power Authority (CANADA)(commercial/industrial)}

\section{Transmission Service - Power Smart Industrial Rate Program}

Commercial/Industrial Schedule 1854 (information provided by Denise Mullen-Dalmer)

I. This is a pilot program intended to reduce the utility's energy requirements by providing incentives for participating customers to conserve energy. Under the terms of this schedule, the utility is required to offer participating customers three pricing options: a non-firm, 3-month option; a non-firm, 6-month option; and a firm 6-month option. The rates for each option are derived from the Mid-C LLH price based on a procedure defined in this schedule.

II. The program is set to expire on July 31, 2002 and the utility is to provide an evaluation of the program by September 30, 2002.

III. The pricing of the program incorporates a 25 percent winter peak premium and a 35 percent firm premium relative to the Non-Firm LLH Base Price, which is set at 50 percent of the Mid-C LLH price. The pricing for the various periods would be as shown in the table below.

\begin{tabular}{|l|l|l|}
\hline 3 or 6 Month Non-Firm & HLH & LLH \\
\hline Winter (Nov-Feb) & $62.5 \%$ of Mid-C LLH's ${ }^{1}$ & $\begin{array}{l}50 \% \text { of Mid-C } \\
\text { LLH's }\end{array}$ \\
\hline Spring (May-June) & $50 \%$ of Mid-C LLH's & 33 \$/MWH \\
\hline All other Months & $50 \%$ of Mid-C LLH's & $\begin{array}{l}50 \% \text { of Mid-C } \\
\text { LLH's }\end{array}$ \\
\hline
\end{tabular}

\begin{tabular}{|l|l|l|}
\hline 6 Month Firm & HLH & LLH \\
\hline Winter (Nov-Feb) & $84.375 \%$ of Mid-C LLH's ${ }^{2}$ & $\begin{array}{l}50 \% \text { of Mid-C } \\
\text { LLH's }\end{array}$ \\
\hline Spring (May-June) & $50 \%$ of Mid-C LLH's & 33 \$/MWH \\
\hline All other Months & $50 \%$ of Mid-C LLH's & $\begin{array}{l}50 \% \text { of Mid-C } \\
\text { LLH's }\end{array}$ \\
\hline
\end{tabular}

Note: $\quad 1 . \quad$ Base Price ( $50 \%$ of Mid-C) times $1.25=62.5 \%$ of Mid-C.

IV. A meter is required. 
Curtailment

A curtailment program is for customers who volunteer to reduce their load or "power-down."

\section{Xcel Energy (commercial/industrial)}

\section{Committed Program}

Commercial/Industrial (information provided by product portfolio manager)

I. Customers receive monthly discounts on their demand charge in exchange for interrupting load when requested by the utility. The demand charge goes to pay for facilities, generation equipment, and transmission lines, substations, etc., and is the largest part of the rate. It is split by season. The committed program is available in Minnesota, Wisconsin, North Dakota, South Dakota, Colorado, Texas, and New Mexico. The programs differ by state, but generally participants must provide a minimum amount of controllable load and will receive a year round credit or discount in their demand charge for all the load they agree to control.

II. Over 2,850 customers are participating in the program, with over 2,250 of them in Minnesota.

III. Customers generally save between $\$ 2.80$ and $\$ 4.50$ per $\mathrm{kW}$ per month in demand charges. This comes in the form of a reduced credit in their demand charge, for example instead of charging them $\$ 9.26$, charge them $\$ 4.43$ for the load they agree to control. There is approximately $965 \mathrm{MW}$ available for control on a design day over the entire service territory. The rates paid in this program were determined by the state Public Utilities Commission.

IV. A meter is required in this program. The customer charge covers the cost of this meter.

\section{Xcel Energy (commercial/industrial)}

\section{Peak Day Partners}

Commercial/Industrial ( information provided by product portfolio manager)

I. This is a voluntary program where customers with a minimum amount of $500 \mathrm{~kW}$ of controllable load can participate. Customers receive a phone call to check their email for a curtailment offer (both time period and price), and decide whether or not to participate. This program is offered only after all other load control programs have been dispatched.

II. This program has 26 participants and offers approximately $50 \mathrm{MW}$ of potential and voluntary controllable load.

III. The customer receives a credit on their utility bill after participating. Customer payments are based upon the offer price, multiplied by an historical load profile calculated from 5 previous non-controlled periods for each hour of accepted control. Prices offered in the program are determined by market conditions.

IV. An interval data recorder is required. Most customers in this usage class already have an interval data recorder installed. The utility is currently in the process of implementing a new tool to require customers to have Internet access, a text capable pager, and/or a text addressable cell phone to notify them of a pending offer. They 
will also be required to have a dedicated phone line to receive historic load profile information used to calculate their credit. 


\section{Pasadena Water and Power (commercial/industrial)}

\section{Load Curtailment Program}

Commercial/Industrial (information taken from rate schedule)

I. This is a voluntary program where large commercial and industrial customers voluntarily reduce (curtail) load upon the utility's request during peak demand periods. Customers can reduce usage of the utility's power by selecting loads for curtailment, utilizing backup generators, or a combination of both. The California Independent Systems Operator contacts the utility to tell them if there is a shortage in the system. The utility then signals a third party, who then pages the customer to indicate that the customer's load curtailment is needed. The third party monitors the curtailment. The program is open to those customers who can reduce $100 \mathrm{~kW}$ or more per electric meter. There is no penalty for lack of curtailment, consequently, no guarantee that the utility will meet its curtailment goal during a given event.

II. This was the $2^{\text {nd }}$ most successful load curtailment program in California for the summer of 2001. The utility's total load is $300 \mathrm{MW}$ 's. Nineteen customers signed a contract for this program. More than 40 meters were involved. If all customers participated at the same time, this program had the potential to save $7 \mathrm{MW}$.

III. There are two costs to the utility: 1) a standby charge paid to the customer based on the amount they could potentially curtail. The price at which this was set followed the California Energy Commission's demand reduction program guidelines and its prices exactly. The total cost to the utility was $\$ 20 / \mathrm{MW}$ curtailed, $\$ 13 / \mathrm{MW}$ going to the customer just for signing the contract, and \$7/MW going to the third party for monitoring and implementing the program. This standby charge cost the utility an average of $\$ 150,000 /$ month; 2) The utility paid the customer for the actual usage curtailed through this program. The utility would pay the customer 15 cents $/ \mathrm{kWh}$ curtailed. Again, this charge of 15 cents is taken directly from the state's demand relief programs. This program never went into effect, therefore the utility never paid this second charge.

IV. Customers need a two-way pager, Internet access (negotiable), and a meter. The utility pays for the meter installation. However, most were being installed for customers prior to the implementation of this program for a separate time-of-use program. The utility meters cost approximately $\$ 1000$ per meter. The installation cost was also paid by the utility at a cost of between $\$ 300 /$ hour - $\$ 1000 /$ hour. This installation cost and time was a surprise to the utility, because some customers had more than one meter.

\section{Columbia River PUD (residential/commercial)}

\section{Share Our Savings Program}

Residential and Commercial (information taken from program brochure)

I. Each month the utility will read a customer's meter and compare it to the same billing period from last year. If electricity use is reduced by more than $10 \%$, then a customer will receive a monetary credit of 3 cents per $\mathrm{kWh}$ for all savings over $10 \%$. This program applies to all customers and does not need to be signed up for. This program became effective June of 2001 and is contracted with the utility's wholesale power provider to operate until September of 2003. 
II. Over the period July 2001 to December 2001, the program saved a total of 6.3 million residential kWh's and 1.9 million commercial kWh's. There were 29,135 residential participants and 2,908 commercial participants in this program.

III. The customer receives compensation in the form of a monetary credit to their electric bill.

IV. No special meters are required for this program.

\section{Pacific Gas \& Electric (20/20)}

California 20/20 Program (information taken from rate schedule)

\section{Retail electric service customers}

I. In this program if a customer reduces their electricity use by at least 20 percent, as compared to the same billing period a year ago, they will receive a monetary credit equal to 20 percent of their summer electric bills.

II. The utility kept track of August numbers and found that 38 percent of residential customers reached the 20 percent goal. That is equivalent to about 1.5 million customers. Program rebates totaled about $\$ 19$ million. Nearly 160,000 or 26 percent of commercial, industrial, and agricultural customers qualified for rebates worth approximately $\$ 18$ million.

III. The 20 percent compensation is in the form of a monetary credit to the customer's electric bill.

IV. No special meters are required.

\section{Sempra San Diego Gas \& Electric (20/20)}

California 20/20 Program (information taken from rate schedule)

Retail electric service customers

I. As in other California programs, if a customer reduces their electricity use by at least $20 \%$, as compared to the same billing period a year ago, they will receive a monetary credit equal to $20 \%$ of their summer electric bills.

II. Number of participants is not available.

III. The $20 \%$ compensation is in the form of a monetary credit to the customer's electric bill.

IV. No special meters are required.

\section{Sacramento Municipal Utility District (commercial/industrial)}

\section{Voluntary Emergency Curtailment Program}

Commercial/Industrial (information taken from rate schedule)

I. In this voluntary program, school districts, the city and county of Sacramento, other government offices, and a variety of business customers agree in advance to reduce non-essential energy use by a predetermined amount (typically about 10 percent) when called upon by the utility. Participants must have a capacity of between 100 and $500 \mathrm{~kW}$ to participate. 
II. There are 130 commercial, industrial, and institutional customers currently participating in this program. About half are public entities and half private. Approximately $88 \mathrm{~kW}$ 's have been identified as loads available in an emergency situation.

III. There is no compensation involved with participation in this program. It is strictly voluntary.

IV. There are no special meters required. Customers do need to have 2 to 3 phone lines

so that they can be contacted when an emergency event occurs. During an event, customers are identified through a computer system and then contacted.

\section{California Independent Systems Operator (CAISO) (commercial/industrial)}

Discretionary Load Curtailment Program (information provided by account manager) This voluntary program was designed to attract smaller customers, such as commercial lighting and air conditioner loads. It pays customers an incentive to curtail load when called upon by the California Independent System Operator. Curtailment is requested on a day-ahead or day-of basis, participants select the times that they will curtail, and there are three metering options (interval, statistical estimation, and sub-meter). Performance is calculated by the California Independent System Operator and payment begins at $\$ 350 / \mathrm{MWh}$. No other information is available.

\section{California Energy Commission (commercial)}

Cash for Kilowatts Program (information provided by Mike Messenger, CEC)

I. Customers and/or aggregators are provided cash incentives of up to $\$ 150 / \mathrm{kW}$ of capacity reduction pledge to install interval meters and the communications necessary to respond to requests for reductions from the California Independent Systems Operator or UDC's. Customer response is voluntary, and depends on whether the customers have signed up for any pay for capacity or energy demand response programs. The capacity reduction estimate pledged in the contract or grant is verified during a pilot test from $2 \mathrm{pm}$ to $6 \mathrm{pm}$ to measure the actual load reduction achieved before the critical summer period begins.

II. Over 300 customers installed systems and provided roughly $200 \mathrm{MW}$ of demand reduction capability for the summer of 2001. However, curtailments were only called once during the summer of 2001 on July $3^{\text {rd }}$ due to conservation response that limited the number of stage 2 emergencies to 1 event all summer.

III. Utility energy and capacity prices for curtailments are proposed, debated, and approved by the California Public Utilities Commission. The California Department of Water Resources also has a small bidding program that allows it to respond to price bids to curtail specific amounts of load during high price periods.

IV. A meter capable of recording electricity use every 15 minutes is required. 


\section{PacifiCorp PowerForward Program (Utah) (commercial/residential)}

Conservation Curtailment (information provided by Jeff Burks,UT)

I. PowerForward was a collaborative, statewide energy conservation information campaign sponsored by the State of Utah, the media and Utah's public and investor owned utilities. The campaign was designed to provide real-time information alerting consumers to those days during the summer (and times during the day) when conservation was necessary to maintain affordable and reliable supplies of electricity.

The foundation of the campaign is the PowerForward Alert Network. State energy conservation experts created an alert system to notify consumers of times when power demand and prices were high. The alert system is keyed to three familiar colors, green, yellow and red. Each color is indicative of the level of energy conservation needed on a given day or peak demand period during a day. Television, radio and cable companies agreed to broadcast the alerts, giving the public real-time updates when the need for conservation is high. The public was also encouraged to sign up to receive personal email alerts using the state's PowerForward website: www.PowerForward.utah.gov.

PowerForward Website. In addition to notifying consumers during key energy-usage times, the PowerForward initiative was designed to help educate Utahns about the need and value of conservation. Through the website consumers had access to information about practical, voluntary low-cost and no-cost actions individuals and businesses could take to reduce non-essential electricity use during peak hours of the summer. In this program customers were informed of high priced or low supply days and urged to reduce power consumption.

II. During the summer PowerForward campaign, four "yellow" alerts were issued. There were no declared "red" alerts. PacifiCorp estimates that on weekdays in which "Yellow" alerts were issued, Utah consumer's conservation efforts resulted in an average demand reduction of 88 megawatts of electric power. Municipal power estimated their demand was reduced by approximately 10 megawatts.

III. Not applicable. Program costs were $\$ 95,000$.

IV. No meters are required, though you need to receive a newspaper, listen to the radio, or watch TV.

\section{PacifiCorp (agricultural)}

\section{Irrigation Curtailment Program Rider}

Agricultural Schedule 72 (*Idaho, Oregon, Utah, *Washington)

I. This was an optional program for customers who curtailed load throughout the 2001 irrigation season in exchange for payment by the utility. The irrigation season for Idaho and Utah ran June 1 through September 15. The irrigation season for Oregon and Washington ran May 1 through November 30. Participating customers had to have a total pumping operation of no less than 16 horsepower.

II. Number of participants is not available. 
III. The program payment was based on the customer's average monthly energy $(\mathrm{kWh})$ usage during the immediate five years of previous seasonal metered irrigation service. For customers with less than five years historical usage, the average for the available years of historical usage, and a comparison to the average usage for similar agricultural pumping operations will be used. The program pays customers differently in different states (see table below) $/ \mathrm{kWh}$. In some states the rate is different for customers who completely disconnect their pumps from the utility's grid or if they do not. The penalty for non-compliance results in the forfeiture of payments to the customer. Furthermore, customers consuming energy above the program requirements will be billed an excess consumption rate as seen in the table below $/ \mathrm{kWh}$. The utility will periodically monitor and check participating customer farm operations to assure program compliance. The utility waives the fee for disconnecting and reconnecting customers to the grid.

\begin{tabular}{|l|l|l|l|c|}
\hline \multicolumn{1}{|c|}{ state } & \multicolumn{2}{c|}{ payment /kWh } & \multicolumn{1}{c|}{$\begin{array}{c}\text { excess consumption } \\
\text { penalty /kWh }\end{array}$} & season \\
\hline & $\begin{array}{l}\text { disconnected } \\
\text { from grid }\end{array}$ & $\begin{array}{l}\text { no } \\
\text { disconnection }\end{array}$ & & \\
\hline Idaho & 15 cents & 13.5 cents & 27 cents & June $1-$ Sept 15 \\
\hline Utah & 15 cents & 13.5 cents & 27 cents & June $1-$ Sept 15 \\
\hline Oregon & 12.5 cents & -- & 25 cents & May 1 - Nov 30 \\
\hline Washington & 12.5 cents & -- & 25 cents & May $1-$ Nov 30 \\
\hline
\end{tabular}

The benefit to the customer is paying a lower rate for energy consumed and avoiding a higher charge for over consumption.

IV. No meter required.

*Washington - 1800 eligible customers, 134 participated. Average Monthly Savings was 2,800 MWhs. (information provided by Nick Garcia, WA)

*Idaho - 15 cents per kWh saved. (information provided by Bill Eastlake, ID)

\section{PacifiCorp (Utah) (irrigation/industrial)}

Bilateral Contracts (information provided by Jeff Burks,UT)

\section{Irrigation/Industrial}

I. These were voluntary efforts where customers and the utility agreed upon terms and conditions of curtailment.

II. In Utah, several industrial customers negotiated curtailment agreements and a standard program was approved for irrigation customers. The industrial curtailment prices varied and the irrigation customers earned the Commission approved rate.

III. The utility curtailment prices were based on conditions in the unregulated wholesale market or indexed, including analysis on what the value of curtailment will be. The benefit to the customer is cash or a credit to their future bill.

IV. No additional meters required.

Sierra Pacific Power Company (commercial) Optional Conservation Service 
Curtailment Schedule OC (information provided by Carl Linvill)

I. Under this schedule, the total monthly metered demand must exceed $1 \mathrm{MW}$ and demand designated as curtailable must exceed five hundred (500) kW. A customer must also have a $500 \mathrm{~kW}$ generator or greater and the demand designated as curtailable must exceed five hundred (500) $\mathrm{kW}$. Service is restricted to a cumulative total curtailment load not to exceed $100 \mathrm{MW}$. The utility will contact the customer for voluntary curtailment by 10 am two days prior to the time of curtailment. In no case will this tariff be applicable during periods of mandatory curtailment or outage. The customer is under no obligation to curtail when contacted by the utility, but may confirm their intent to curtail at the time of the notification on a first-come-first-served basis up to the amount of curtailment requested by the utility by $2 \mathrm{pm}$ on the date of notification. Curtailed demand by dedicated metering or by review of existing interval metering data shall determine the amount of verifiable curtailed demand. Verification will include a review of previous similar 10 day load profiles. Customer participation is required for one year.

II. Number of participants is not available.

III. The billing credit to the customer shall be equal to the Market Credit* less the Displaced Revenues**. The verified curtailed demand/hour shall be multiplied by 50 percent of market price as determined by the California-Oregon Border on peak index for two business days prior to the curtailment notice. Under certain circumstances the utility may contact the customer with less than two days notice to request curtailment at a negotiated market price. The customer must maintain a minimum of 80 percent of the Contract Curtailable Load reduction for the entire time period to receive the billing credit. The penalty for failing to interrupt includes a forfeiture of the billing credit for the curtailment period. It may also result in the immediate termination of the curtailment service.

IV. A meter is required as are communication related devices needed to transmit and receive information regarding the status of curtailable loads and/or providing the customer with notification via telephonic messages or other methods.

*Market Credit - the verifiable curtailed demand in each hour which is multiplied by 50 percent of market price as determined by the California-Oregon Border on peak index for two business days prior to the day the utility issues a notice to curtail.

**Displaced Revenues - are calculated as the difference, if positive, in demand revenue based on the actual metered demand plus the verified curtailed demand, and the demand revenue based on the actual metered demand for the billing month.

\section{Nevada Power Company (commercial)}

\section{Optional Conservation Service}

\section{Curtailment Schedule OC (information provided by Carl Linvill)}

I. Under this schedule, the total monthly metered demand must exceed $1 \mathrm{MW}$ and demand designated as curtailable must exceed five hundred (500) kW. A customer must also have a $500 \mathrm{~kW}$ generator or greater and the demand designated as curtailable must exceed five hundred (500) $\mathrm{kW}$. Service is restricted to a cumulative total curtailment load not to exceed $100 \mathrm{MW}$. The 
utility will contact the customer for voluntary curtailment by 10 am two days prior to the time of curtailment. In no case will this tariff be applicable during periods of mandatory curtailment or outage. The customer is under no obligation to curtail when contacted by the utility, but may confirm their intent to curtail at the time of the notification on a first-come-first-served basis up to the amount of curtailment requested by the utility by $2 \mathrm{pm}$ on the date of notification. Curtailed demand by dedicated metering or by review of existing interval metering data shall determine the amount of verifiable curtailed demand. Verification will include a review of previous similar 10 day load profiles. Customer participation is required for one year.

II. Number of participants is not available.

III. The billing credit to the customer shall be equal to the Market Credit* less the Displaced Revenues**. The verified curtailed demand/hour shall be multiplied by 50 percent of market price as determined by the California-Oregon Border on peak index for two business days prior to the curtailment notice. Under certain circumstances the utility may contact the customer with less than two days notice to request curtailment at a negotiated market price. The customer must maintain a minimum of 80 percent of the Contract Curtailable Load reduction for the entire time period to receive the billing credit. The penalty for failing to interrupt includes a forfeiture of the billing credit for the curtailment period. It may also result in the immediate termination of the curtailment service.

IV. A meter is required as are communication related devices needed to transmit and receive information regarding the status of curtailable loads and/or providing the customer with notification via telephonic messages or other methods.

\footnotetext{
*Market Credit - the verifiable curtailed demand in each hour which is multiplied by 50 percent of market price as determined by the California-Oregon Border on peak index for two business days prior to the day the utility issues a notice to curtail.

**Displaced Revenues - are calculated as the difference, if positive, in demand revenue based on the actual metered demand, plus the verified curtailed demand, and the demand revenue based on the actual metered demand for the billing month.
} 


\title{
Appendix B - State Responses to DR Survey
}

After the release of the WIEB report, Summary of Western States/Provinces

Demand Response Programs, states were surveyed in an effort to assess the success of implementing demand response programs. Questions included:

1. Is there or has there been an order or decision that sets forth rules that says the commission must use a policy that directs utilities to use specific criteria by which to evaluate an IRP?

2. What rationale is your puc, psc using for not moving ahead with demand response initiatives?

3. In your opinion, what broader lessons have been learned from encouraging the demand response process.

4. What programs have been successful? Why?

5. What programs failed? Why? What could have been done differently?

6. What can states do to help ensure the effectiveness of state or utility DR programs?

Below is a summary of state responses. Opinions expressed herein are not necessarily reflective of a state commission, commissioners, or other agency.

\begin{abstract}
Alberta $^{38}$
The wholesale market is completely restructured in Alberta. Most demand response is industrial. The restructuring of the retail market should be complete by 2005 . If small commercial customers don't enter into a demand response contract with retailers, they will receive service under the default supply option based on the pool price flow-through rate. The reaction in Alberta is mixed and guardedly optimistic. The ISO operates the market and part of their duties is to plan the system capacity, transmission planning etc. Close to $3000 \mathrm{MW}$ will be coming on line. Because Alberta only has a gas market for residential customers, there is limited opportunity for demand response for residential communities. Lessons learned include: if you expose consumers to price signals, they will respond.
\end{abstract}

\section{Arizona}

Arizona does not have a need for demand response programs due to a robust wholesale market.

\footnotetext{
${ }^{38}$ State/provincial feedback was received via phone conversations with state/provincial and LSE officials: Bevan Laing (Alberta Department of Resource Development) 09/03; Jerry Smith (Arizona Corporation Commission) 09/03; Paul Wieringa (British Columbia Ministry of Energy \& Mines) 09/03; Bruce Kaneshiro and Moises Chavez (California PUC) 09/03; Wendell Winger (Colorado PUC) 09/03, 05/04; Bill Eastlake and Lynn Anderson (Idaho PUC) 09/03, 05/04; Will Rosquist (Montana PSC) 09/03; Deb Young (Northwestern Energy) 05/04; Dick Burdette (Nevada Energy Office) 09/03; Kirby Lampley (Nevada PUC) 09/03; Prasad Potturi (New Mexico PUC) 09/03; Lisa Schwartz (Oregon PUC) 09/03, 05/04; Rebecca Wilson and Mary Cleveland (Public Service Commission of Utah) 09/03; Nicholas Garcia (Washington Utilities and Transportation Commission) 09/03, 05/04; Bryce Freeman (Wyoming PSC) $09 / 03$.
} 


\section{British Columbia}

Currently load curtailment is done through DSM, however, BC will implement TOU and stepped rates by 2005 for industrial and commercial customers who qualify as high voltage. The new rates involve getting $90 \%$ of electricity at low cost and the last $10 \%$ at the cost of new supply. The desire is to have a market response, plus a difference in cost between old and new supply. So, rather than having industrial customers see the average cost at the margin, they will see the cost of new supply, which gives them incentive to conserve or buy new supply directly from independent power producers (IPPs) and not from the utility. The goal is to have access to more buyers and more wires. The stumbling block to implementing demand response is the difficulty in designing rates and satisfying customers' desire for simplicity. The greater lesson learned from this exercise is that consumers don't understand the electricity marketplace. They want cost based rates and simplicity.

\section{California}

The CEC opened a rulemaking on demand response in June 2003 and adopted a statewide pilot to test various types of price responsive ideas. An extensive pilot program began summer 2003 with several hundred customers, chosen randomly, and a comparison control group. Ten million dollars was invested. The results will be evaluated fall 2003 and 2004.

The question to be asked is whether demand response is something California wants to invest in? Some at the CPUC are optimistic about the benefits versus costs, others are not. The other questions to be looked at have to do with meters and residential and smaller business customers. Will they and can they participate? The emerging question for larger customers is, would the commission make these types of programs mandatory, because right now they are voluntary? To make it truly work, you must make them mandatory. If voluntary, then programs must be more attractive to customers on the margin. Otherwise, there is a point beyond which it becomes no longer economic.

As for residential and small C\&I customers, the Commission is evaluating the amount of DR that can be attained from these customers through rate offerings/programs. The project is called the Statewide Pricing Pilot (SPP) and is an 18-month project with three primary research objectives:

1. Estimate demand response and associated price elasticities of customers exposed to time differentiated rates (time-of-use, variable and fixed Critical Peak Pricing), information, and/or technology treatments.

2. Determine customer preferences among different tariff attributes and market shares for specific TOU and dynamic tariffs, control technologies and information treatments under alternative deployment strategies.

3. Evaluate the effectiveness and customer perceptions of specific pilot features and materials, enrollment and education materials, bill formats, web information, and tariff features. 
The results from the SPP will be used to design new rate/tariff offerings and estimate the demand response that can be achieved through these tariff offerings. Results will be used as input for a cost/benefit analysis of implementing an Advance Metering Infrastructure (AMI).

\section{Colorado}

Customers of the state's primary utility have an interruptible rate option. The pilot interruptible rates for the C\&I sectors have been in effect since 1997, but participation has been low. Customers have also had a TOU regular tariff option since 1997. The program does not work well because the state has not deregulated its electric industry. There needs to be a 3-1 or 4-1 difference between on peak and off peak rates in order for it to work. In general, if customers are to respond, rates must be adjusted a lot, not a little. People don't have enough incentive. People are not interested unless there is a big price difference.

Real time pricing efforts have failed, but more proposals are coming. There is more room for commercial customers in real time pricing because meters are in place already, but there are still challenges with regard to revenues generated and hitting the target on rate of return regulations. As far as what states can do to support DR, it's expensive to try solutions and you need to be careful.

\section{Idaho}

Cultural attitudes and the potential for lost revenues due to demand response, which cuts into overall energy sales, is a problem.

\section{Successful programs}

Various customer "buy-back" programs worked well, i.e. customers responded to the incentives offered. Problems with buy-backs include the inability to accurately measure the kWh bought, the non-sustainability of buy-backs, and, of course, the "lost revenues" issue. Also, in hindsight, there is a question of whether too much incentive was offered through too many buy-back and other DSM programs.

Pacificorp is in its 2nd year of a successful irrigation scheduling program in which irrigators are paid to have their pumping curtailed. Pacificorp's seasonal and diurnal time-of-use rates that it has offered residential customers as an option for two decades are quite popular with customers.

\section{$\underline{\text { Pilot programs }}$}

Idaho Power is entering its second summer of cycling a limited number of residential air conditioners. Idaho Power is in its first year of its irrigation "peak clipping" program in which it pays irrigators to allow their pumps to be shut off for a few hours each week. Idaho Power is in the process of installing advanced meters for a few thousand of its customers as required by the IPUC and in anticipation of testing critical peak TOU pricing. 


\section{Failed programs}

Idaho Power and Avista Utilities offered, or considered offering, commercial and industrial buy-backs, but received no or very little interest in them due to incentives that were too low and/or time periods that were too short.

What states can do to support DR

In May 2004, the Idaho PUC ordered that mandatory TOU rates be phased-in for all schedule 19 (large industrial) customers. Universal, mandatory, critical peak TOU pricing has the potential to make other demand response programs obsolete. In that order the commission also opened a new case to determine how to avoid financial disincentives to Idaho Power for participating in conservation programs.

\section{Montana}

Montana is moving forward with demand response initiatives and, although there is no stated time frame for that process, they recently adopted procurement rules that will apply to a utility resource portfolio.

The Business Partners Program (DSM) offers funding for local energy conservation and load management projects in new and retrofit applications. Initially this included commercial, institutional, industrial, agricultural, and multi-family residential facilities/systems but it has evolved into serving the needs of primarily school and government facilities. NorthWestern Energy solicits proposals for this program through customers, architects, engineers and other energy efficiency trade allies. The program is not a true demand response program run by the utility. It is financed by a Universal System benefits charge that all customers pay on their bill. Retailers who participate in the program get a check back every month.

\section{Nevada}

Nevada needs demand response because of the large amounts of energy it imports. Demand response would provide substantial peak reductions in Nevada. For it to work however, demand response must be seen as a way of changing the terms or conditions under the tariff so customers can be rewarded by allowing a certain fraction of load to be bought at real-time prices instead of being seen as a barrier where customers get paid to take action when they will do it for free.

\section{New Mexico}

Retail markets in the state have not been de-regulated, so utilities have an obligation to plan for and procure the necessary generation to meet load, both currently and in to the future. There already are interruptible rates that customers can take advantage of. Given the above, policymakers are not particularly supportive of demand response.

The state's utilities historically and currently have adequate resources to meet customer demand. The companies don't depend on market purchases to meet firm customer demand. So the usefulness of DR measures is not the same as in cases where formal customer demand is met through spot purchases. Given that customers already have an interruptible option, that aspect is taken care of. 
All utilities in NM have an obligation to procure adequate resources to meet present and future demand with appropriate and prudent results. The commission continuously monitors whether the utilities are carrying that out or not. This has worked well thus far and the utilities submit applications for approval whenever they need to add installed resources into their resources mix. In other words, it is not an explicit rule, just implied policy. Utilities have not failed customers yet so it relies on the companies' obligation to serve and, periodically, in cases that are filed before the commission, the commission is kept apprised of what's going on and sometimes through special investigations and routine monitoring, the adequacy of resources is ensured.

\section{Oregon}

The electricity crisis was the impetus behind the move toward demand response. The better Oregon is able to respond to system contingencies with a variety of programs like demand response, particularly during times of drought, the better prepared they are for future events.

\section{$\underline{\text { Successful programs }}$}

PGE's and PacifiCorp's short-term demand buyback/energy exchange programs during the Western energy crisis in 2000-01 had good participation and large energy reductions. Customers liked being able to choose whether to participate on a per-event basis.

Customer payments were based on current market prices, and the programs helped keep utility costs down.

\section{Failed programs}

PacifiCorp's Seasonal Flux option for residential and small business customers, available March 2002-December 2003, flopped because although nearly all participants saved money on the program, the savings were negligible and participants overall used MORE energy on the new rate option during two out of the three highest-priced months than they did during those same months the prior year (after normalizing data for weather). Further, meter reading (which may occur anytime during the month) was out of sync with rates that varied by calendar month, so customers didn't get the full benefit of responding to price signals.

\section{What states can do to support DR}

States can require that potential demand response programs be evaluated on par with supply-side options in integrated resource plans; encourage RFPs for third-party bidding of demand response options; encourage pilot programs; investigate whether the combination of pricing options, automated meter reading, and other benefits of advanced metering and communications make such technology cost-effective for adoption; carefully review filings for demand response programs and work with the utilities to address any concerns about program design; and require that the utilities evaluate their programs, carefully review evaluation reports and address issues that arise. 


\section{Utah}

Utah is moving ahead with creating a cost effective demand side resource to be used as their peak management strategy. A TOU pilot program began in 2003 for residential and commercial customers. A Pacific Power TOU tariff program began in April 2004 for residential customers who use over $15 \mathrm{~kW}$ hours. An air conditioning load control program began in 2002. Three-tiered rates are available.

\section{Washington}

Due to a fair degree of controversy over the usefulness and effectiveness of demand response mechanisms, Washington has come to no conclusions about whether or not to include demand response in its resource portfolio when interruptible and time-of-use approaches are already being used for power crisis situations. The hydro based utilities, may or may not be moving ahead with demand response because efficiency programs in general are the preferred approach. For utilities that have less hydro, and therefore are more subject to market prices, demand response is more attractive.

\section{Successful programs}

The most successful types of programs were those that paid customers for reducing energy consumption. For example, a $10 \%$ rate reduction if you lowered your consumption by $10 \%$ (This would result in a 19\% bill reduction if one used $10 \%$ less electricity). These were successful because people could see real results from their efforts. There may have been a bit of competition going on amongst people in the community to see who could lower their demand the most. The problem with these types of programs is that they are very expensive for the utility. They only work financially when the wholesale price of electricity becomes exorbitant $(\$ 100+/ \mathrm{MWh})$.

Another successful program paid farmers not to irrigate their fields. These were typically run on a subscription basis and the farmers had to demonstrate they did not plant their crops. This program required a fairly long lead time due the span of time between sowing seed and irrigation.

\section{Failed programs}

Puget Sound Energy had its residential TOU rate modified in a July 2002 rate case. It was determined that the program did not necessarily result in net savings and did not reflect market pricing. The decision affected residents in that, unless residents chose to opt-out, they would be charged $\$ 1 /$ month to participate in the TOU rate.

PSE rushed the implementation of the program at the height of the California crisis. They made no provision for a control group against which to compare the results, and the price differential between peak and off-peak was not that high. PSE's analysis of the program suggested it had very little effect on overall consumption ( $>1 \%$ reduction) and only about $4-5 \%$ of participants switching consumption from peak to off-peak. What was unclear was whether the cost of this switching (meters/data gathering) was worth the benefit gained by lowering peak demand. This is especially important in a hydro-based system that tends towards being energy constrained rather than capacity constrained. One thing that remained a concern was the ability of poor customers to respond to price 
signals (e.g., could laundromat users actually wash their clothes later at night?) The program could have benefited from more up-front planning.

In the public's eye the biggest failures had to do with aluminum smelters. Prior to the crisis, many smelters had entered into fairly inexpensive long-term contracts with BPA for electricity. During the crisis many found they could shut down and earn more money by selling back the power than they could by producing aluminum. As a consequence, most of the smelters shut down and many employees were laid off. While some of the smelters did continue to pay their workers, all-in-all it was a public relations disaster.

\section{What states can do to support DR}

The WUTC is currently in the process of rewriting its utility resource planning rules. No decisions have yet been made as to the content of those revisions. Under current policy, any effort to implement demand response programs would come through the utilities serving the state and most likely start during the development of their Least Cost Plans.

States must explicit regarding their objectives (e.g., lower peak demand by $100 \mathrm{MW}$ ) and put in place a program design that can convincingly determine the actual and specific effect of the program on energy consumption.

\section{Wyoming}

The progression of DR is impacted by the types of loads and resources that fall within PUC's jurisdiction. Wyoming doesn't have large commercial loads that lend themselves to demand response. However, the state does have limited TOU programs associated with irrigation customers. The perception is that there aren't enough savings and benefits available from DR because of the types of loads in WY and lack of structured activity associated with DR and IRP in general. 


\section{Appendix C - Western Interconnection DR Grant Timeline}

I. August 2001 - project contract number DE-FG03-01SF22369

Purpose: Evaluate what demand-reduction measures utilities in the Western states and provinces have undertaken; examine pricing strategies to reduce demand during peak periods using energy efficiency and distributed generation; identify barriers to using price to curb demand; and, to encourage energy efficiency and distributed generation that can enhance demand response capabilities in the Western Interconnection.

II. October 2001 - Workshop

Seattle, Washington

$>$ Purpose - design a demand response project

Two actions were taken to implement a demand response research initiative: (1) State and provincial members volunteered to join a Demand Response Team to guide work under the initiative; and (2) questions were identified regarding key issues that needed to be addressed when considering various demand response initiatives (e.g., demand bidding, real-time pricing).

$>$ Follow-up - Demand Response Team members reviewed suggested additions and modifications to the questions and developed a plan to address the questions.

III. April 2002 $-1^{\text {st }}$ CREPC Workshop

San Diego, California

$>$ Purpose - this session built upon the October workshop in Seattle.

Western states/provinces that have been actively involved in instituting demand response programs shared case studies on the lessons learned from various programs. This included identifying successful programs, as well as programs that have encountered significant obstacles, and paying specific attention to answering the major questions raised in Seattle as well as what the next steps are. The session also examined the importance demand response plays in FERC's final rule on SMD.

$>$ Follow-up - a draft scoping paper was developed, revised and posted on the WIEB website on August 19, 2002.

WIEB staff created a Demand Response Team page on the WIEB web site containing an assortment of related links to materials addressing demand response.

IV. September $2002-2^{\text {nd }} C R E P C$ Workshop

Vancouver, B.C. CANADA

$>$ Purpose - this session focused on an examination of best practices in demand response. WIEB surveyed CREPC members for their preferences on which programs and best practices they were interested in hearing about. 
Presentations were given by PacifiCorp, Georgia Power and representatives from California, Idaho, Washington, Oregon, and Utah. A question and answer period followed, where other states and provinces reported on developments with demand response issues in their jurisdiction.

$>$ Follow-up - A final version of the research paper was posted on the WIEB website on September 26, 2002.

V. June 2003 - Information Update

Denver, Colorado

$>$ WIEB staff updated information on the use of demand response measures in the Western Interconnection. Summary: a) progress is mixed, conversations with states/provinces, suggests that demand response programs are being put on hold, restructured, reassessed, or placed in a study (pilot) mode; b) public utility commissions in Idaho and Oregon are taking the lead in advancing the role of demand response programs in providing electricity service by working with agencies and investor-owned utilities to put demand response programs in place.

VI. November 2003 - Follow-up Phone Interviews

Denver, Colorado

$>$ By phone, WIEB staff interviewed knowledgeable individuals in Western states/provinces regarding the rationale influencing decisions on implementation of demand response programs and potential lessons learned.

VII. March $2004-3^{\text {rd }}$ CREPC workshop

San Francisco, California

$>$ Purpose - The Committee heard presentations on linking demand response programs with Integrated Resource Planning. Topics covered include national trends in demand response and technical and policy issues with integrating demand response into IRPs. 